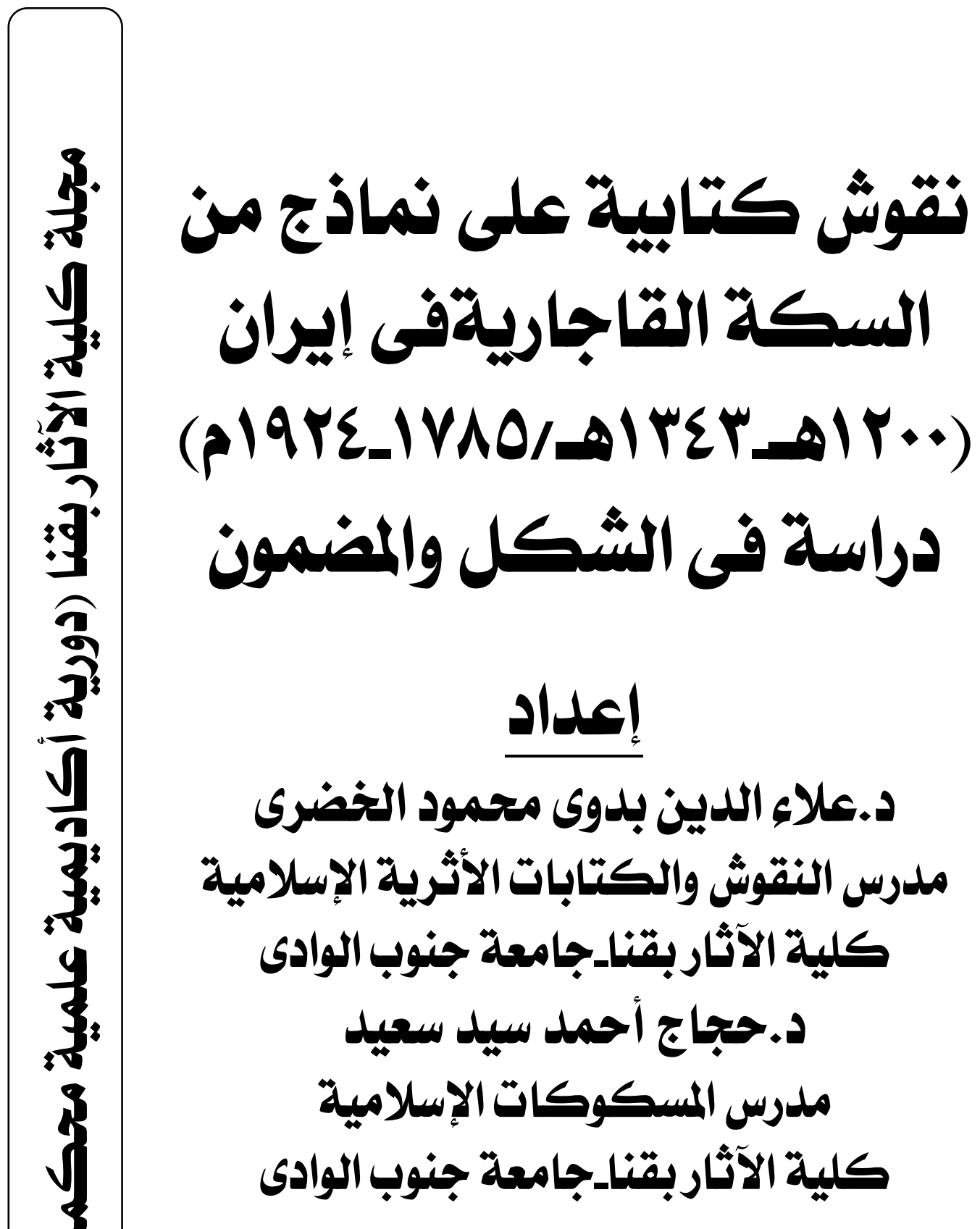





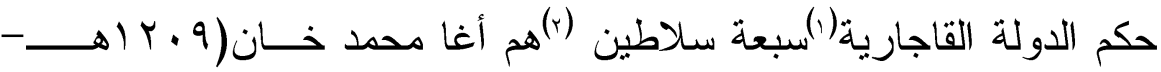

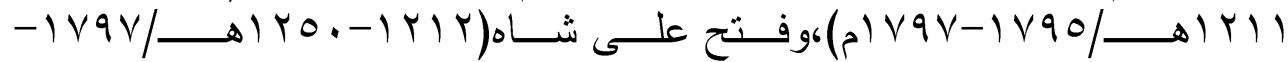

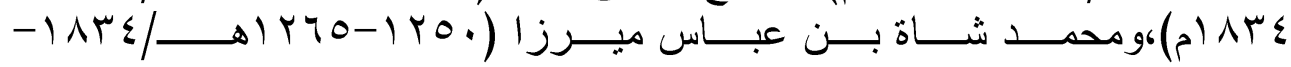

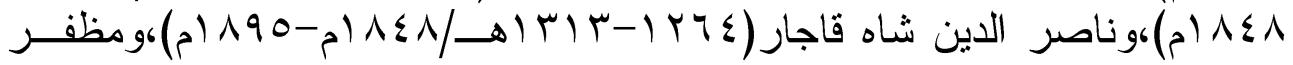

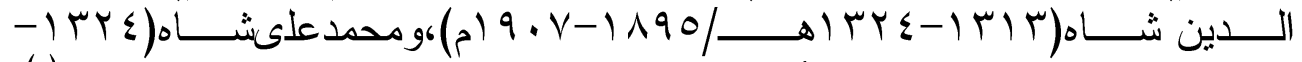

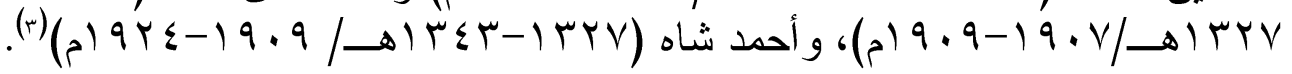

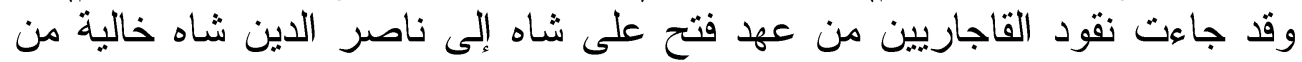

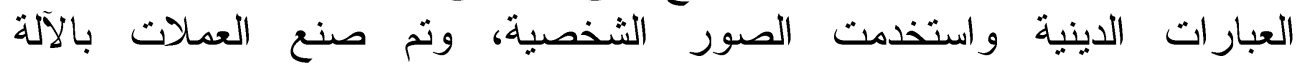

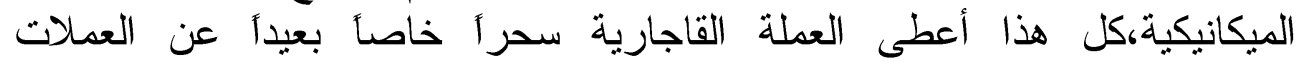

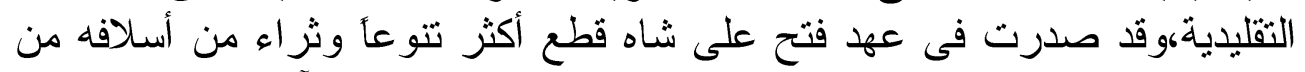

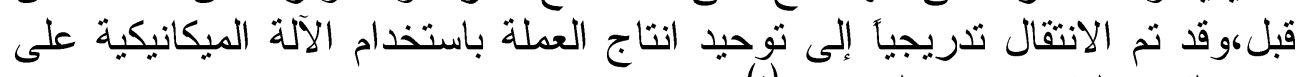

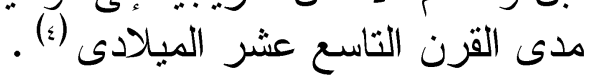

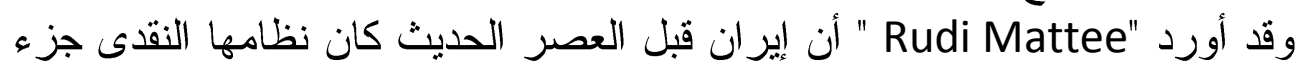

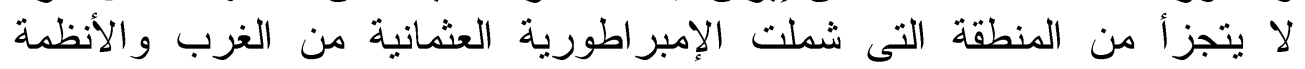

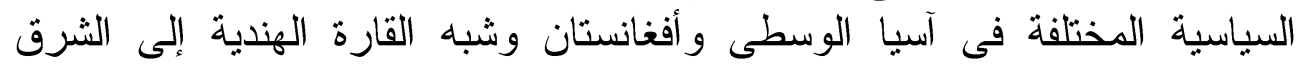

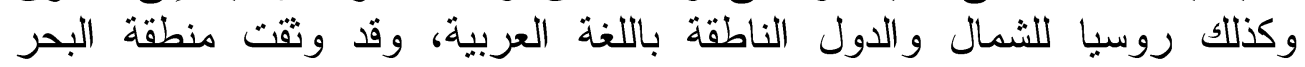

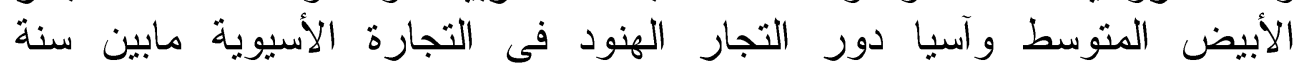

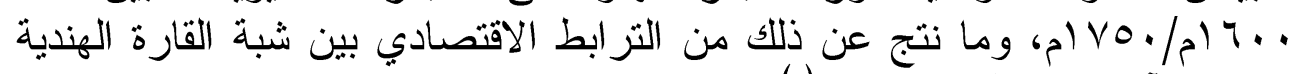

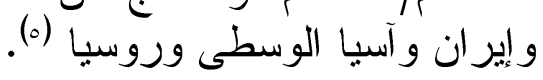

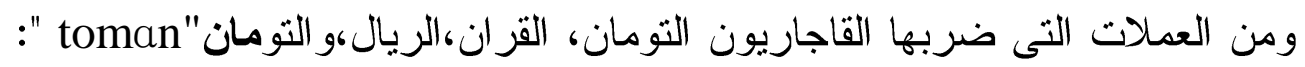

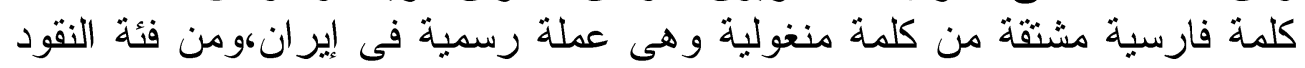

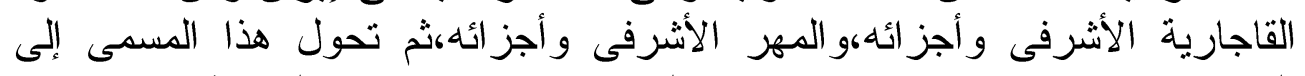

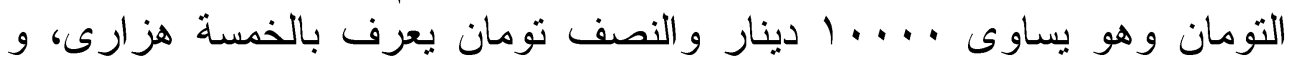

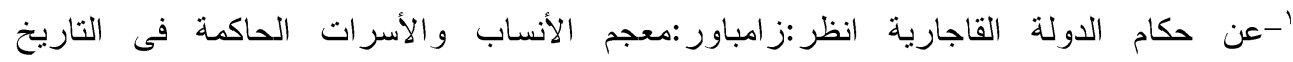

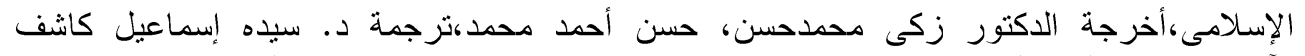

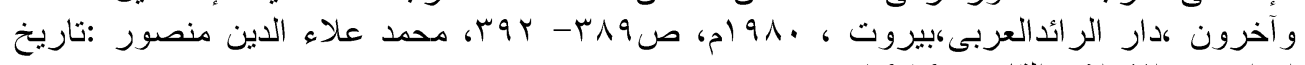

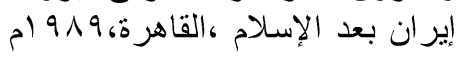

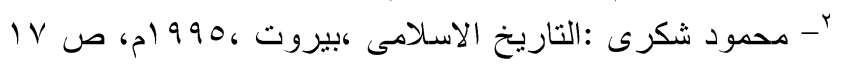

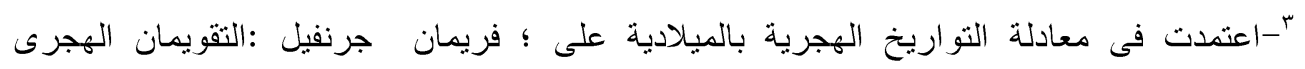

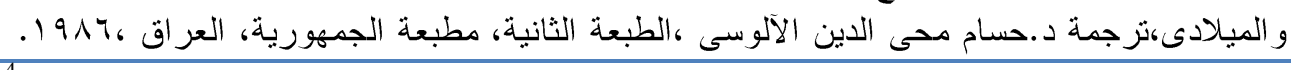
${ }^{4}$-Priscilla Soucek : Coinage of the Qajars: A System in Continual Transition ,Iranian Studies, Vol. 34, No. 1/4, Qajar Art and Society 2001, p. 51.

${ }^{5}$-Priscilla Soucek: Coinage of the Qajars, p. 52. 
التومان نقد ذهبي كان معروفاً فى العراق لمجاورته ايران كوقد اختلفت قيمته حسب

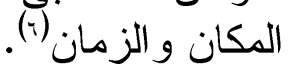

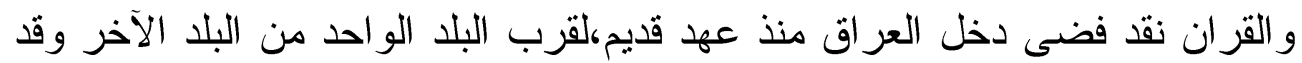
اختلف سعره بين فرنك وبين ما يزيد عليه أو ما ينقص عنه و الكلمة مسماة بلفظ

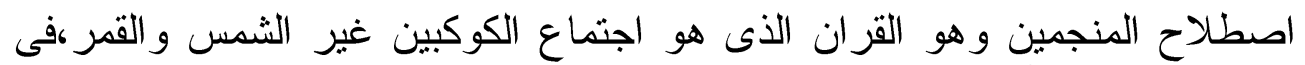

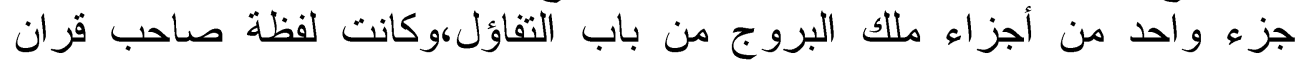
منقوشة على السكة في إيران القاجارية من العهد الصفوى إلى عهد الملك ناصر

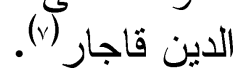
الريال: اسم شائع فى بلاد الثرق الادنى، وأول من أجراه فى السوق والتجارة الأسبانيون و اسمه عندهم Real منمنى الملكى وقد اختلف سعره من مكان لاخر

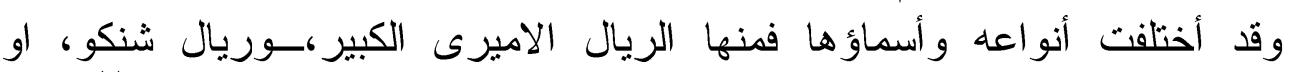

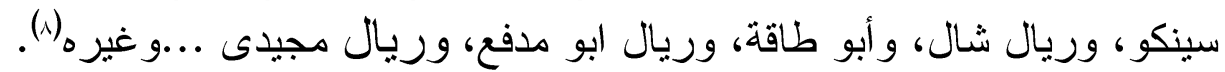

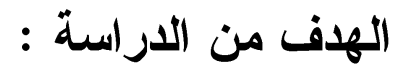

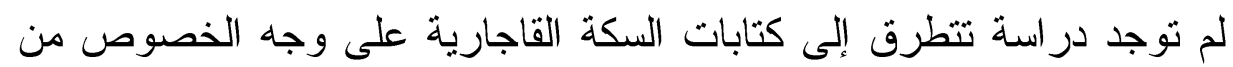
حيث الشكل و المضمون ومن هنا حاولت فى هذا البحث التعرض لشكل الكتابــات

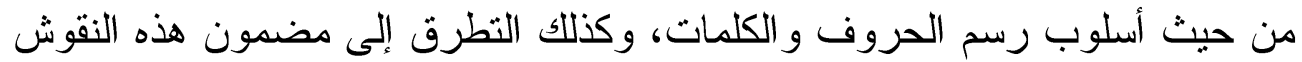

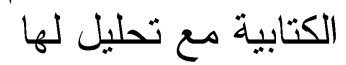

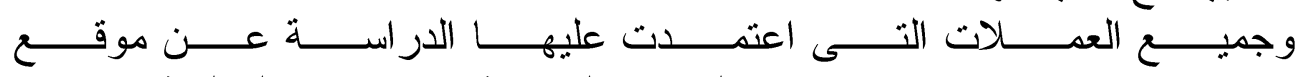
وسWW.coinarchives.com

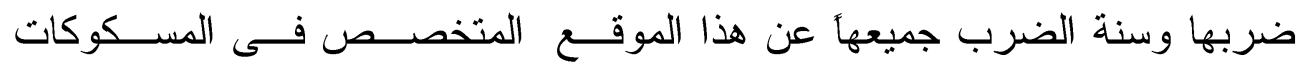

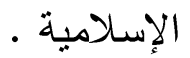

وينقسم هذا البحث إلى مقدمة،وثلاثثة محاور رئيسة:المحور الأول بعنوان: الدراسة الوصفية لنماذج دن السكة القاجارية، أما المحور الثانى بعنوان: دراسة ردة شكل الحروف و الكلمات للسكة القاجاريةهوالمحور الثالث: دراسة مضمون السكة القاجارية

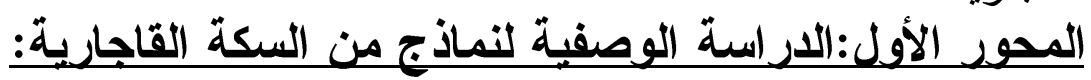

“-مروة عمر محمد حسن المتولى: التصاوير الآدمية و الحيو انية على الخزف و المعادن و النقودالقاجارية

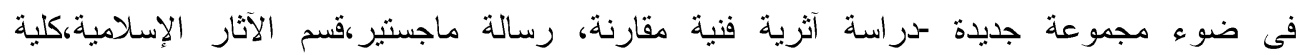

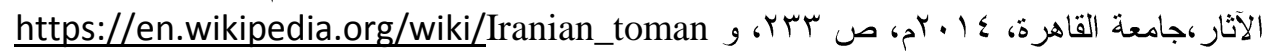

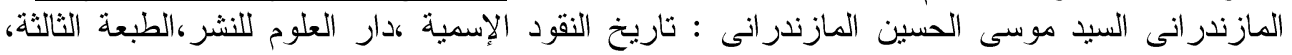

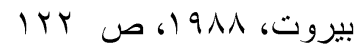

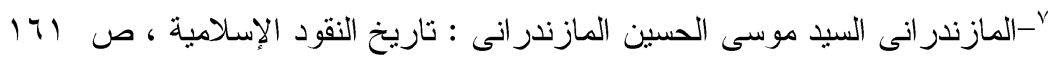

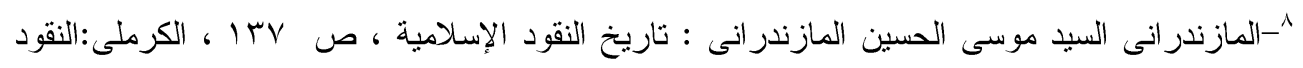

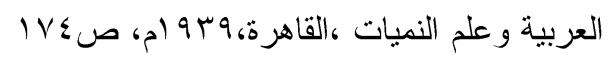




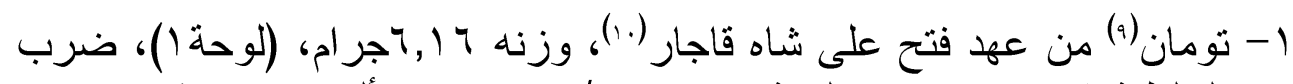

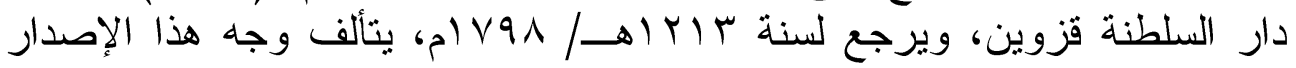

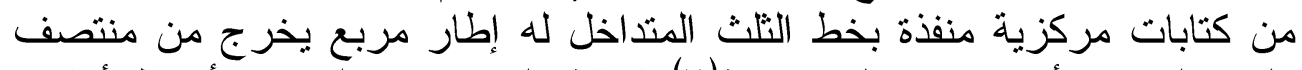

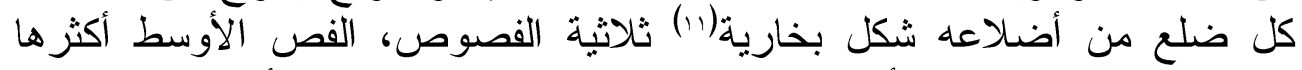

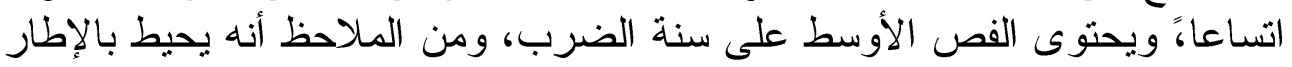

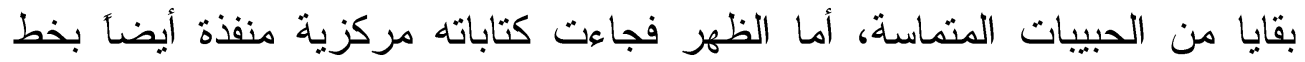

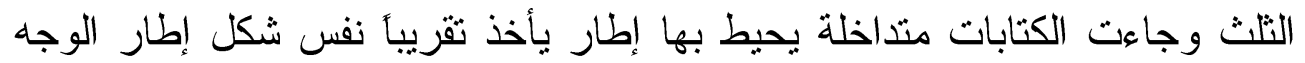

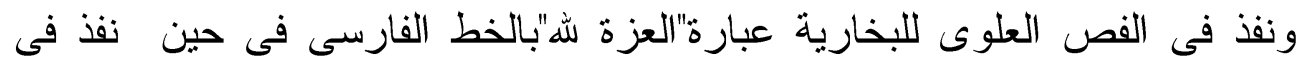

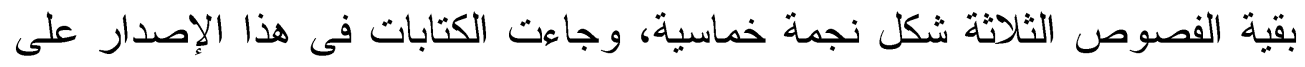

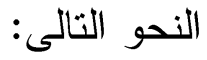

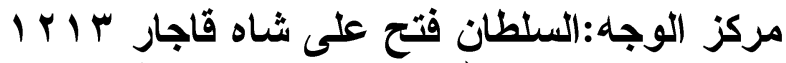

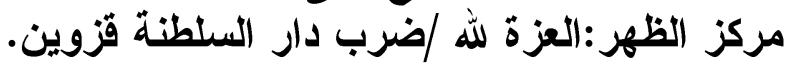

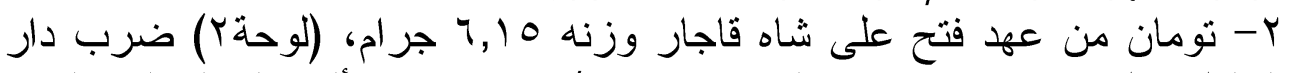

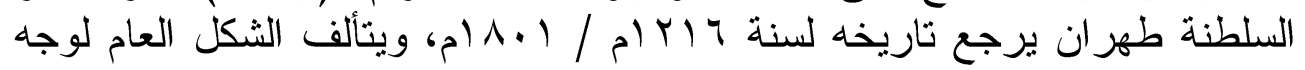

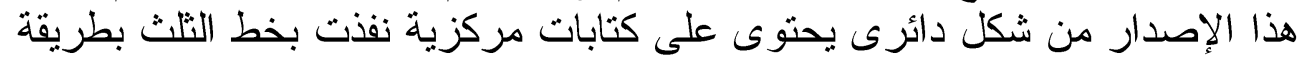

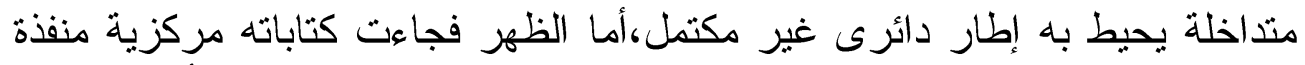

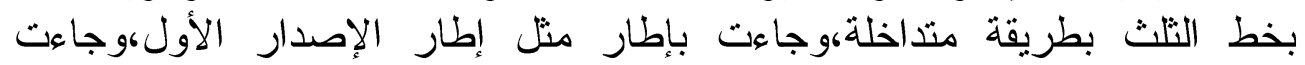

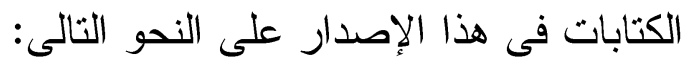

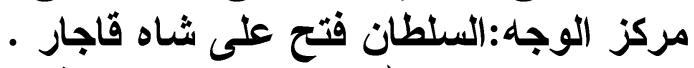

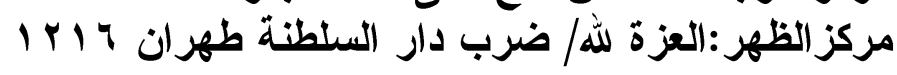

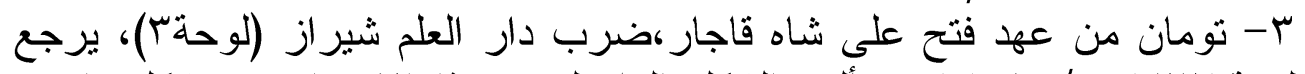

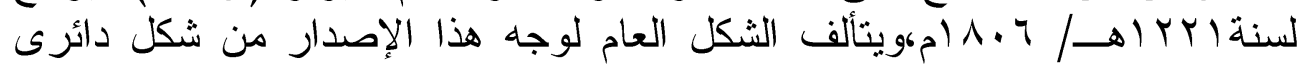
يحتوى على كتابات مركزية نفذت بخط التلث بطريقة متذاخلة يحيط بها لها إطار

9-1' -لمزيد عن نماذج السكة القاجارية انظر : -Regwald Stuart Poole,LL.D: Catalouge of coins of the shahs of persia in the british Museum ,London,1887.,

- H.L.rabino di Borgomale:Coins ,Medals, and Seals of Shahs of Iran‘15001941,Texas, 1973,P64 .

10-Reginald stuart poole: The coins of the shahs of PersiarZand and Kajars,London, 1887,p152

"بخارية: يقصد بالبخارية فى مصطلح أهل الصنعة من الحرفيين وحدة زخرفية ذات شكل دائرى غالباً

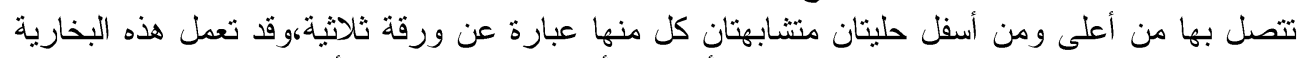

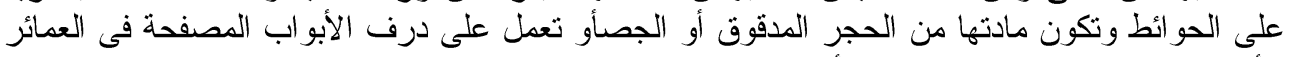

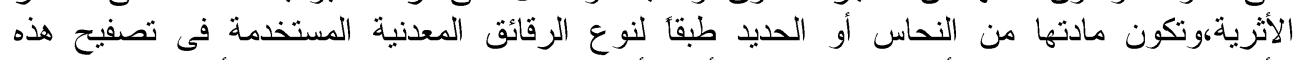

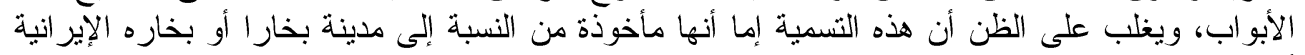

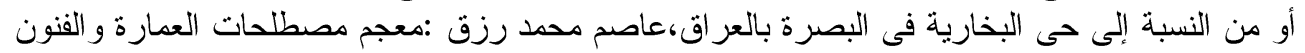

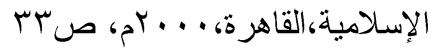


دائرى غير مكتمل،أما الظهر فيتألف من كتابات منفذة بخط النستعليق،وجاءت

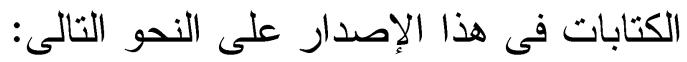

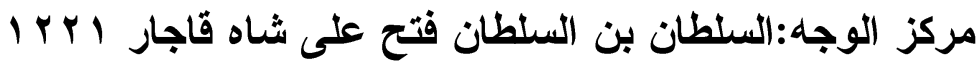

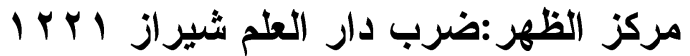

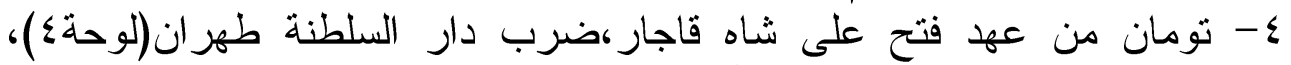

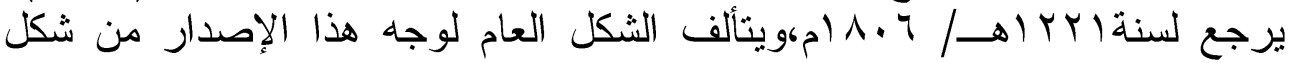

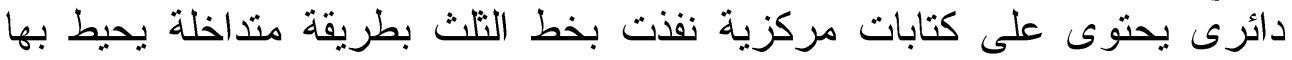

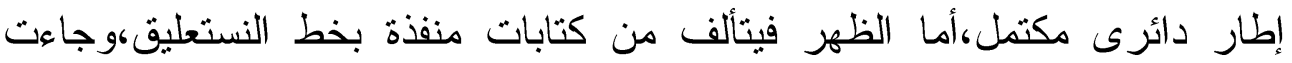

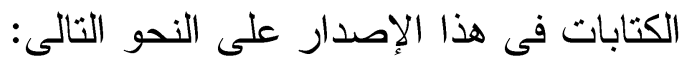

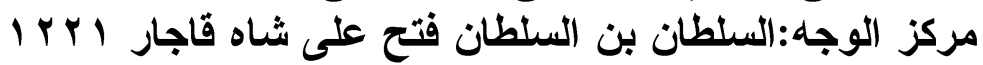

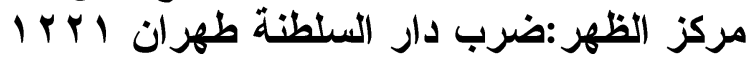

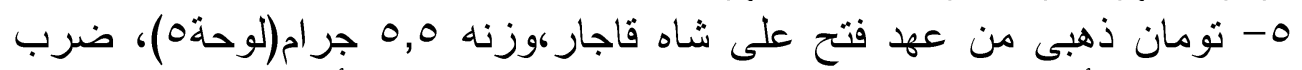

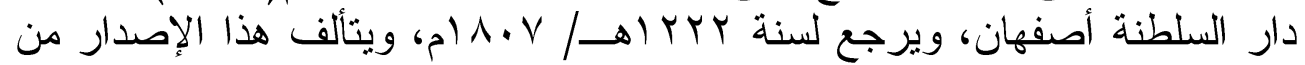

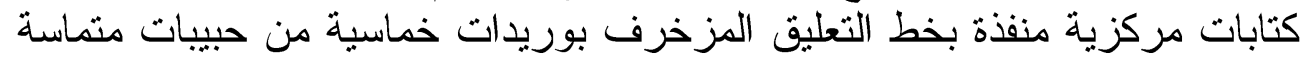

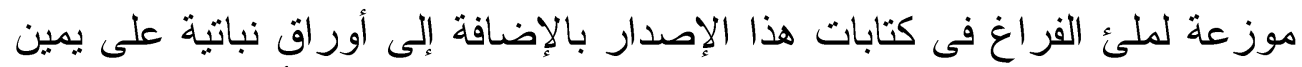

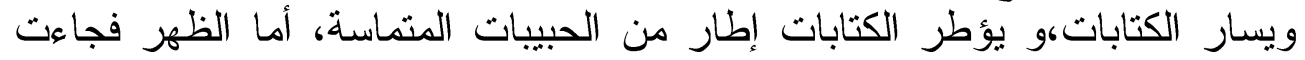

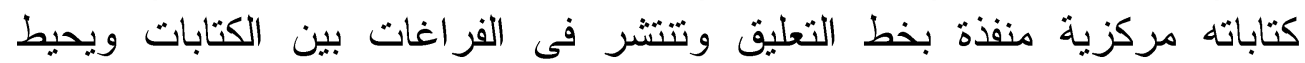

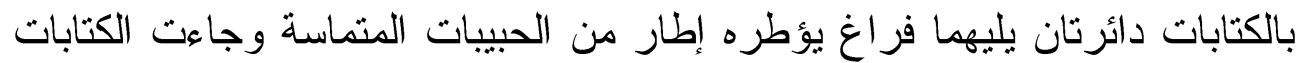

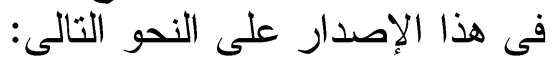

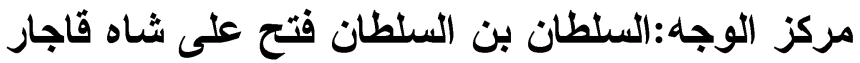

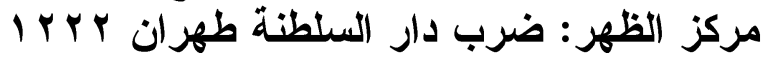

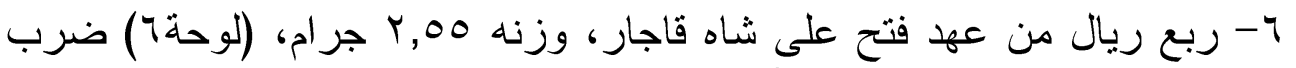

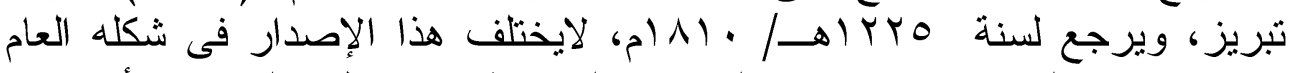

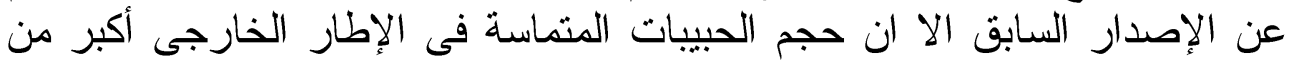

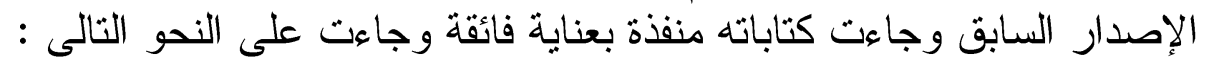

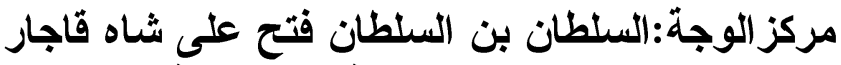

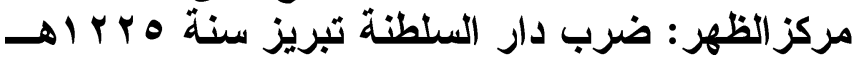

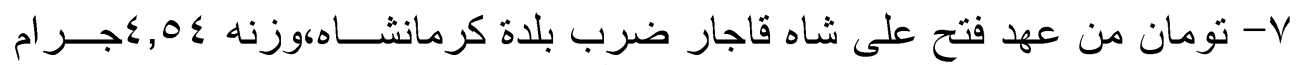

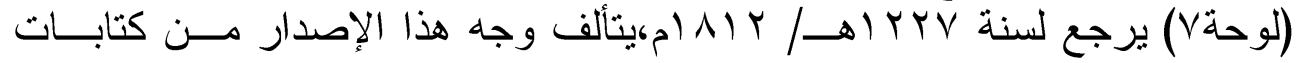

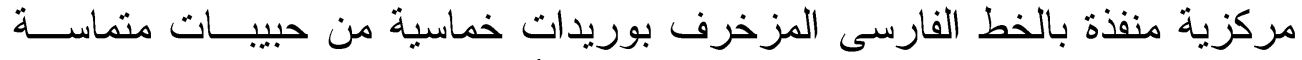

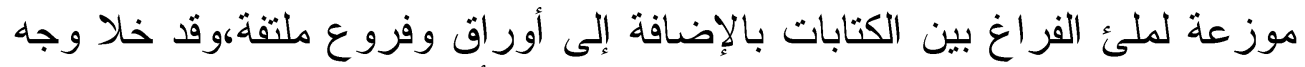

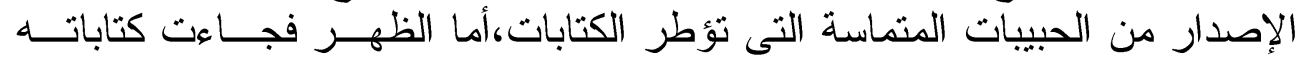

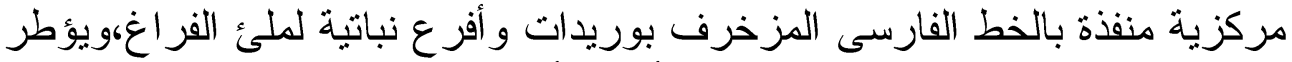

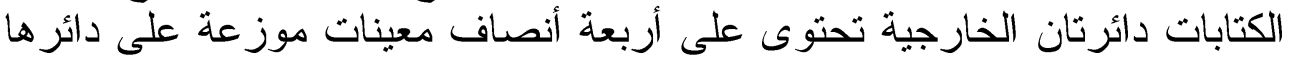

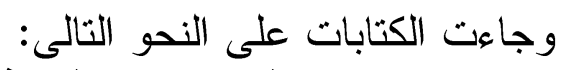

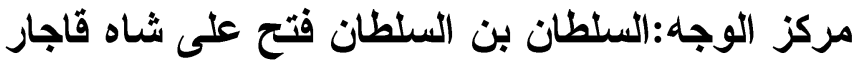

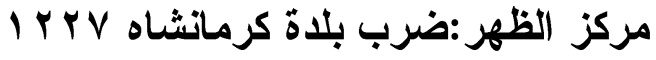




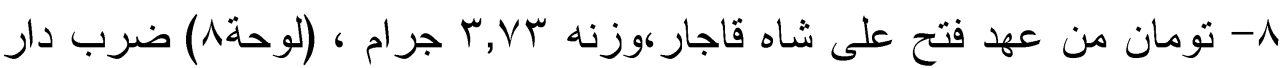

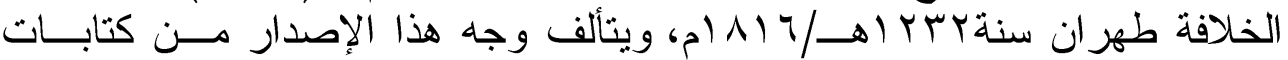

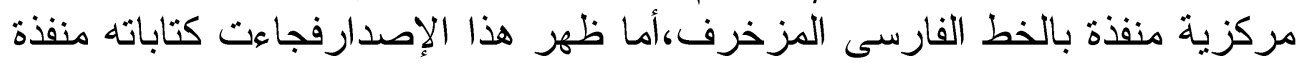

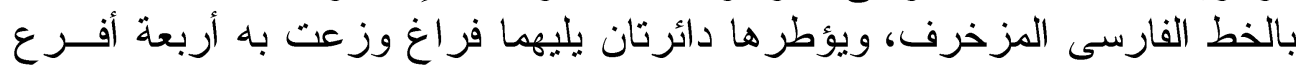

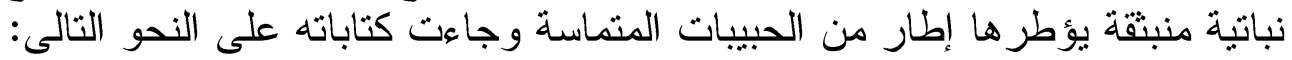

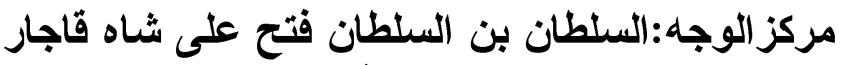

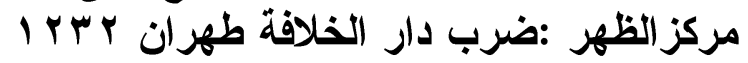

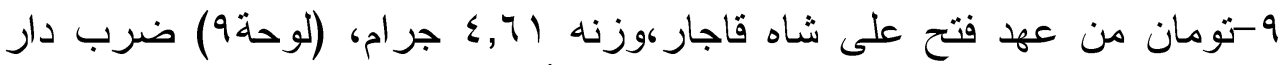

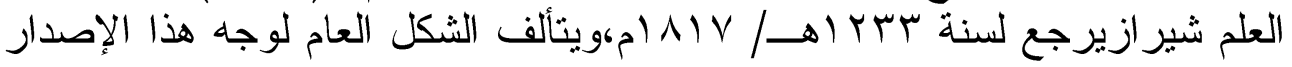

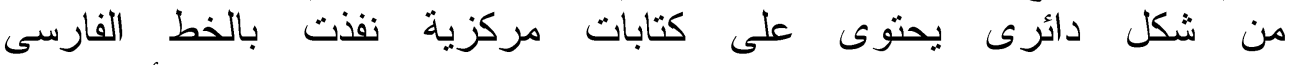

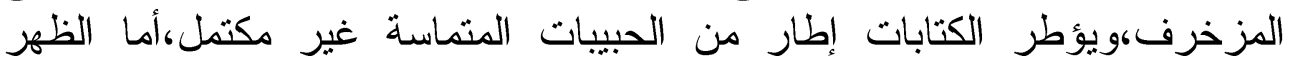

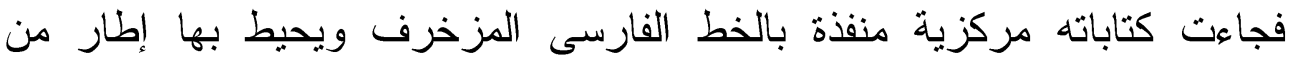

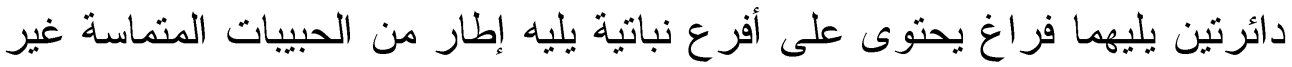

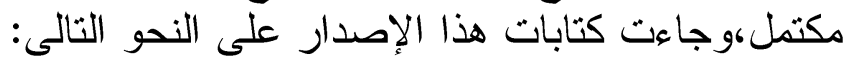

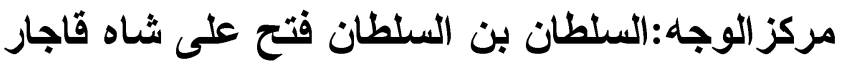

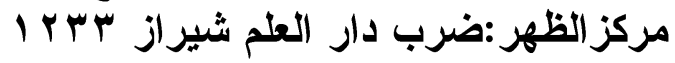

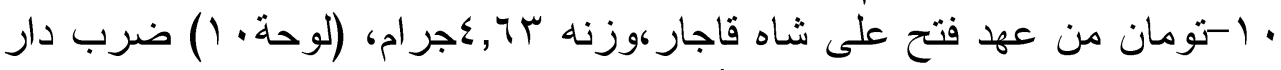

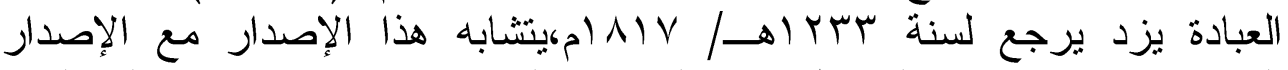

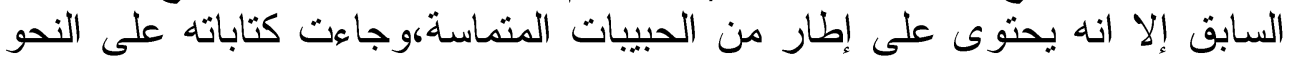
التالى:

مركز الوجه:السلطان بن السلطان فتح على شاه قاجار

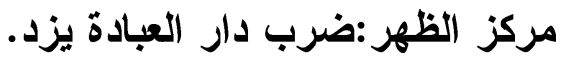

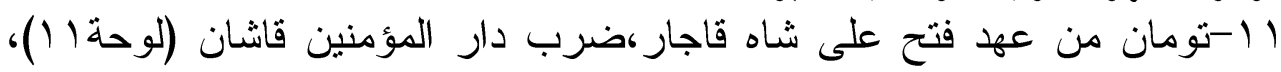

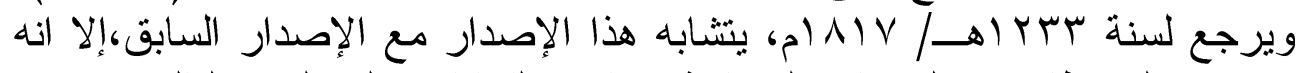

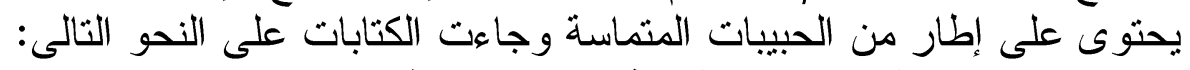

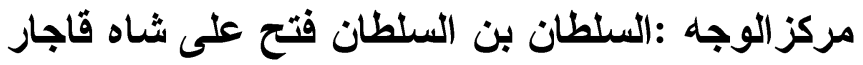

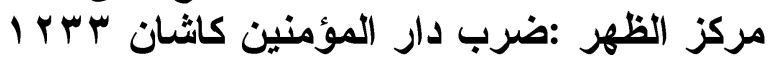

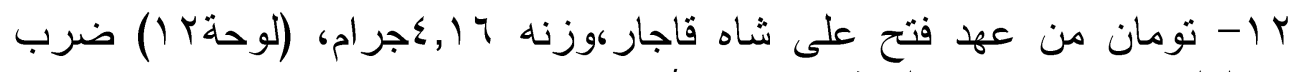

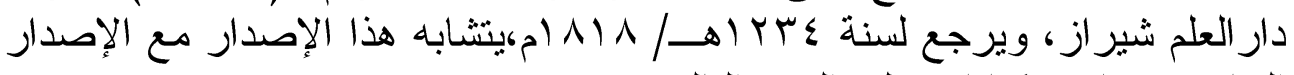

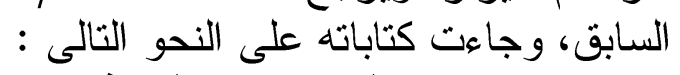

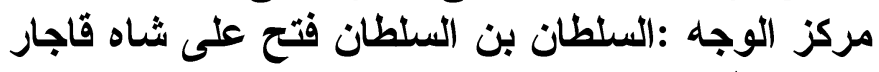

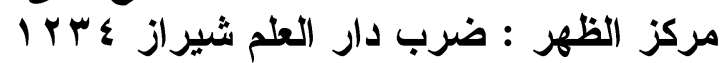

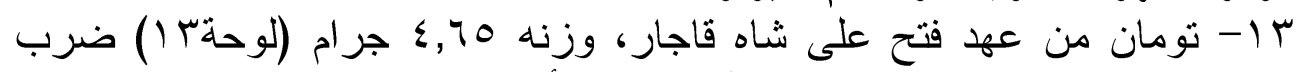

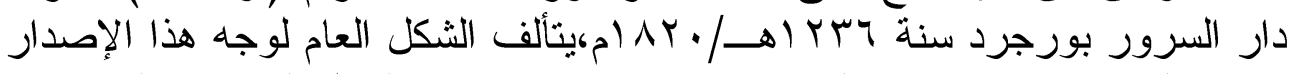

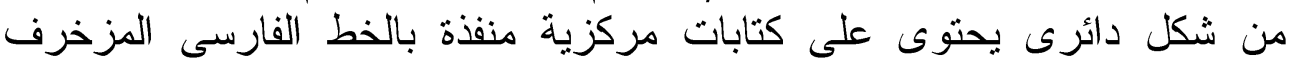

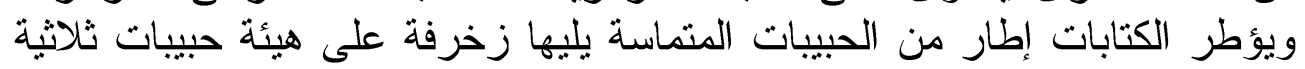

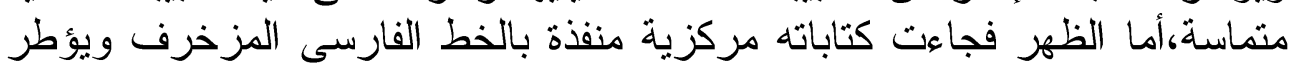


الكتابات إطار من الحبيبات المتماسة يليه زخرفة على هيئة حبيبات ثلاثية متماسة

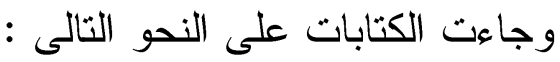

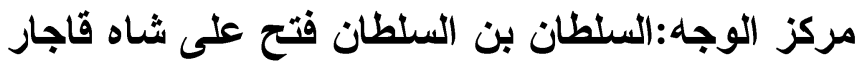

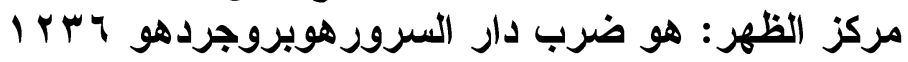

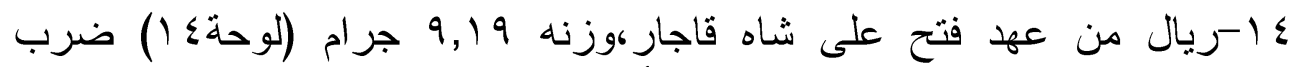

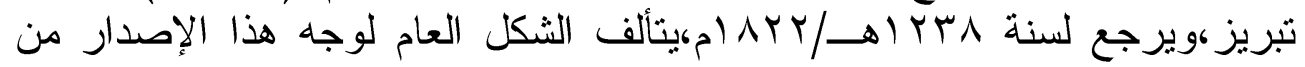

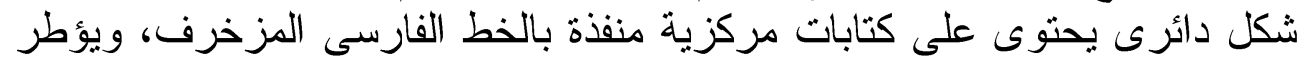

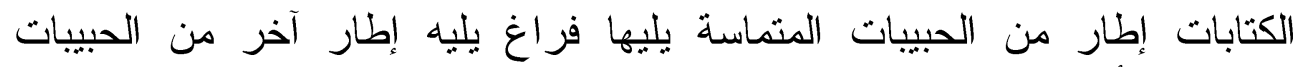

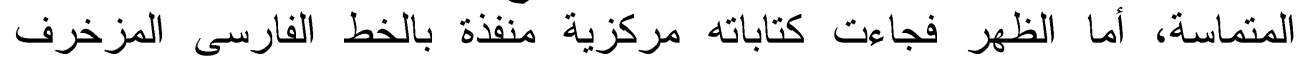

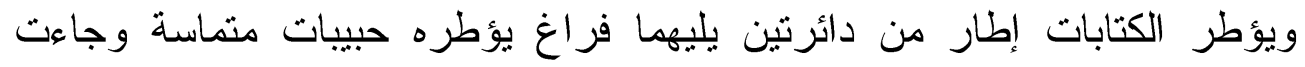

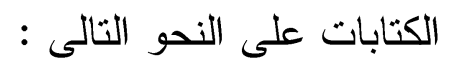

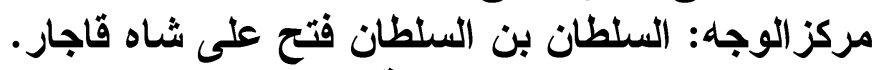

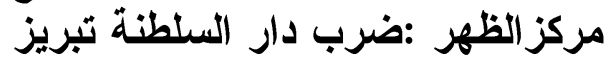

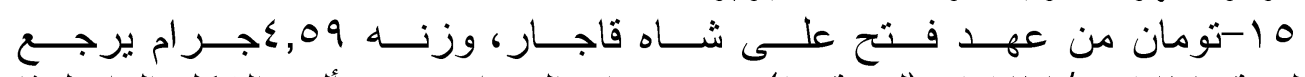

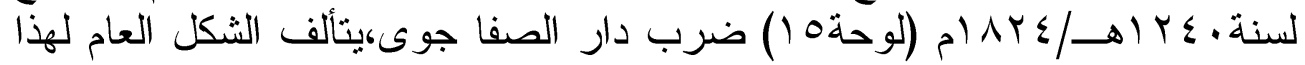

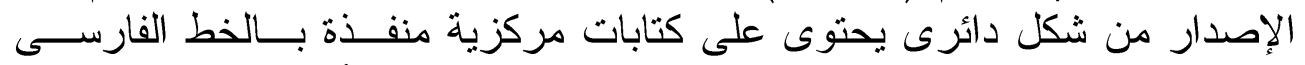

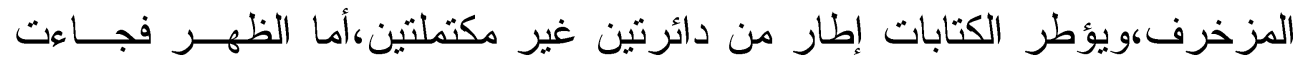

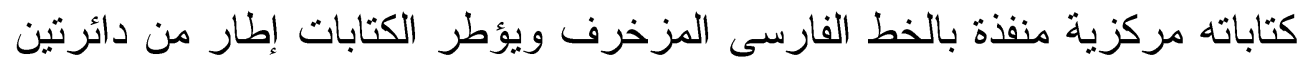

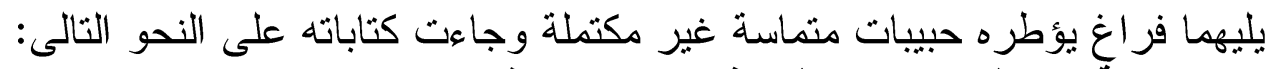

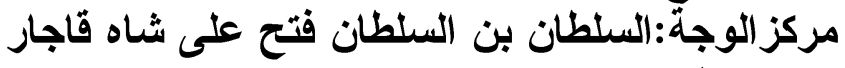

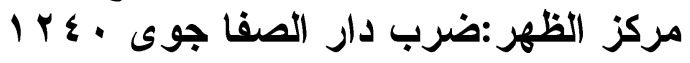

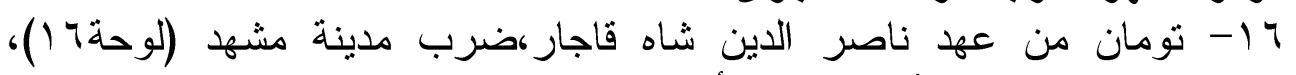

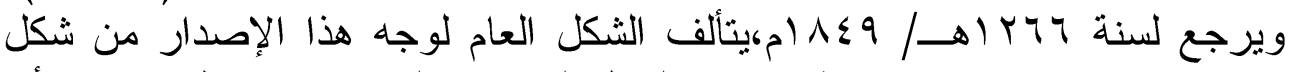

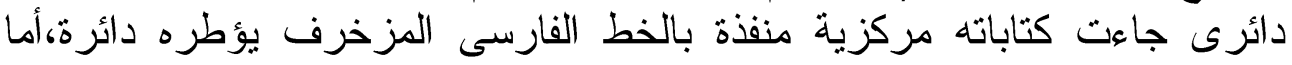

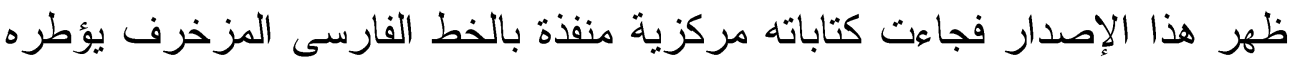

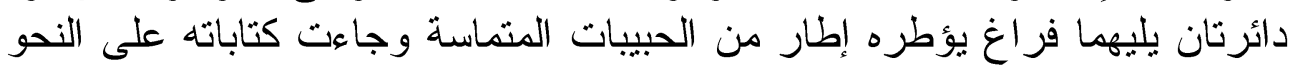
التالى : دائرن

مركز الوجه :السلطان بن السلطان ناصر الاين شاه قاجار

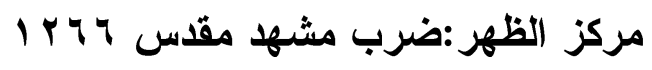

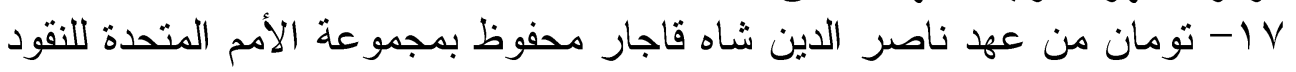

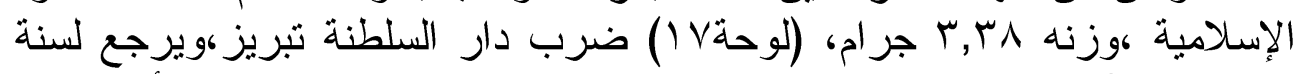

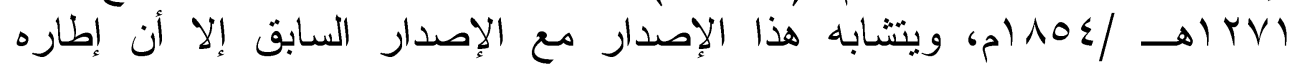

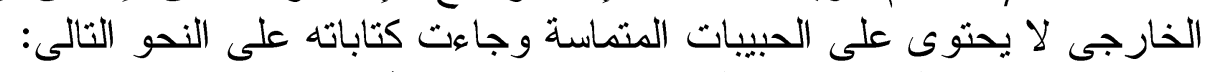

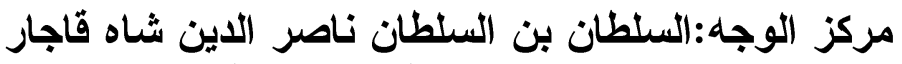

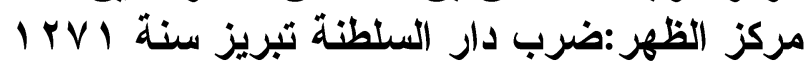

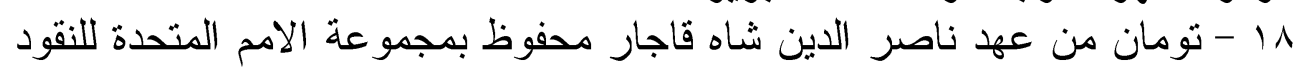

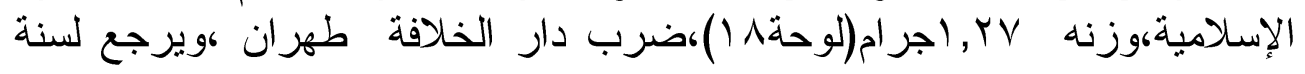




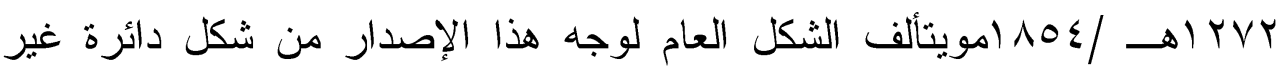

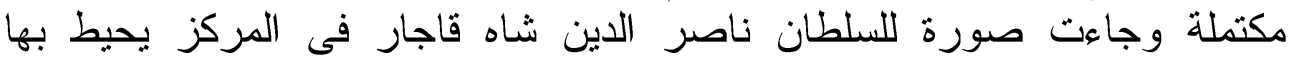

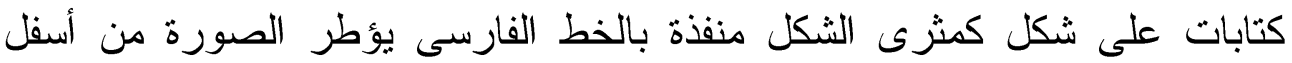

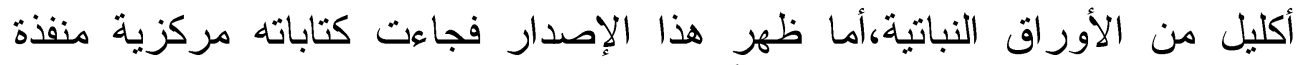

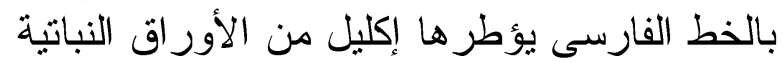
الوجه:سلطان ناصر الاين شأرساه

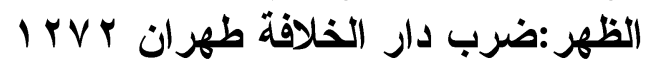

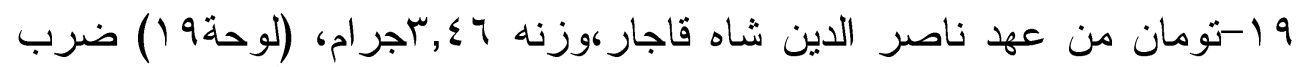

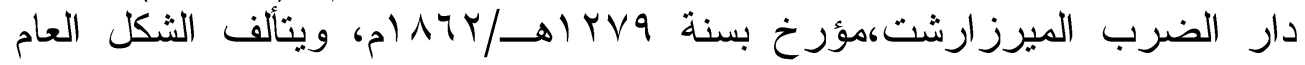

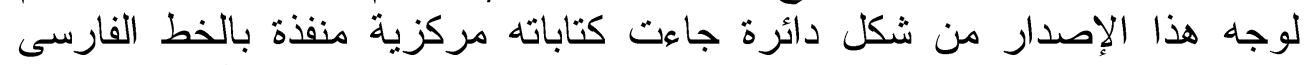

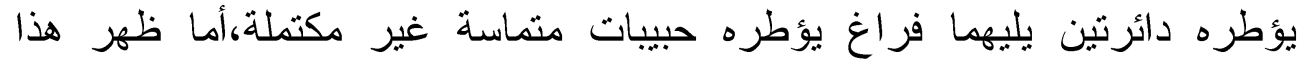

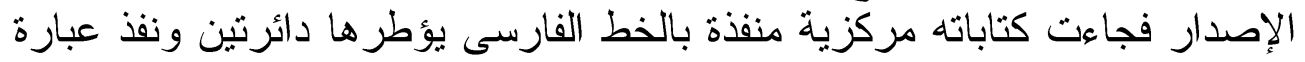

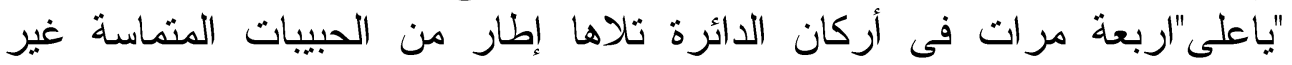

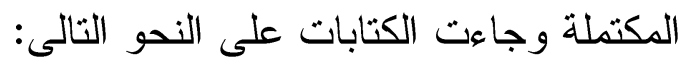

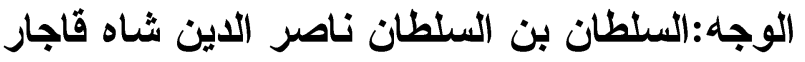

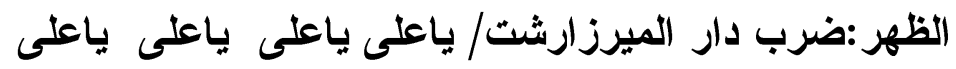

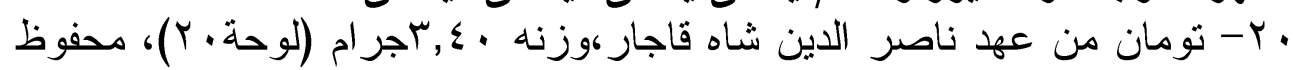

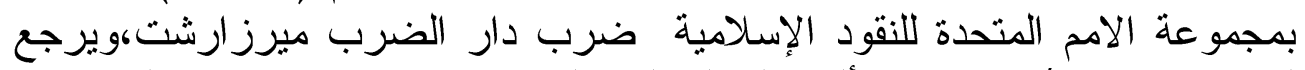

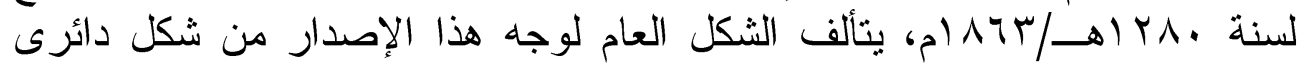

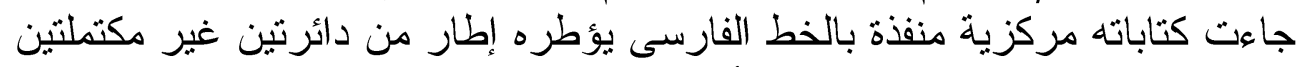

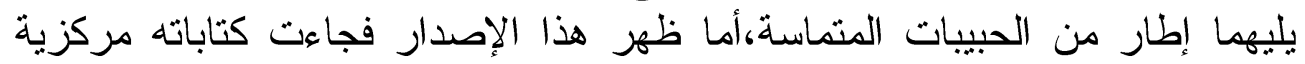

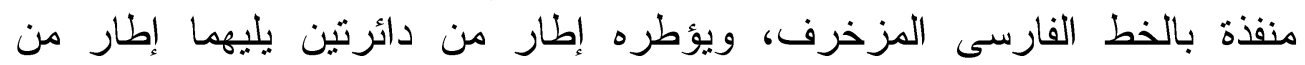

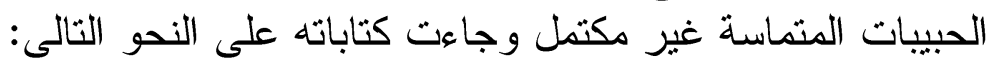

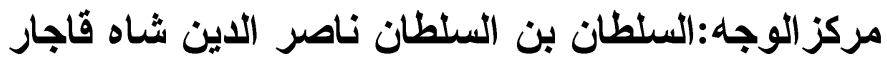

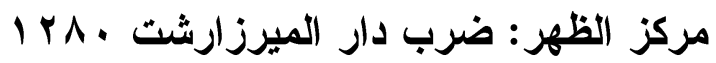

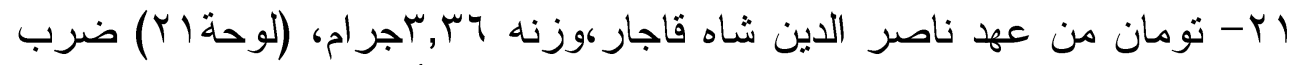

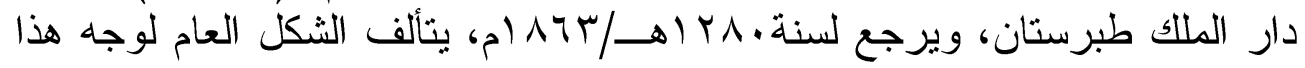

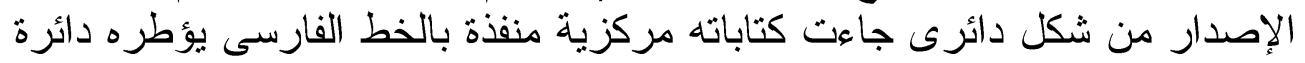

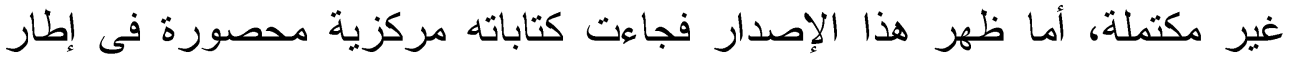

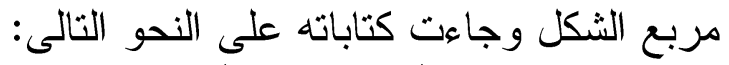

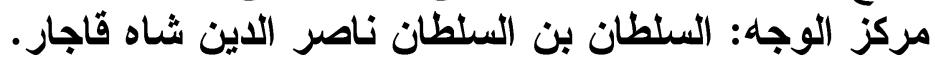

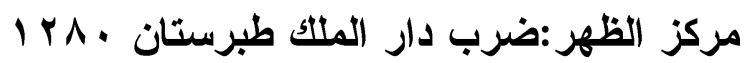

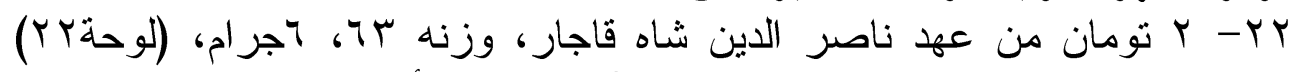

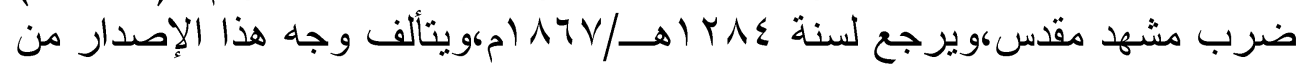


شكل دائرى جاءت كتاباته مركزية عبارة عن طغراء (r)، باسم السلطان ناصر

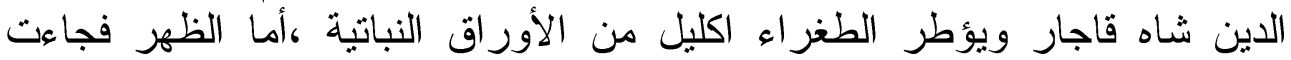

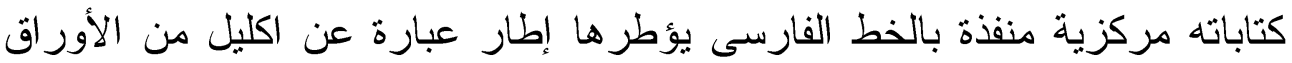

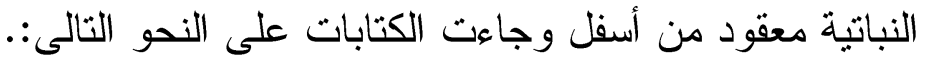

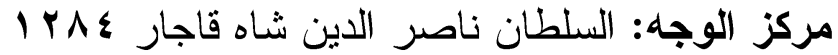

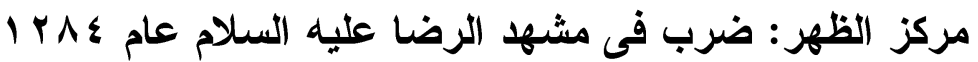

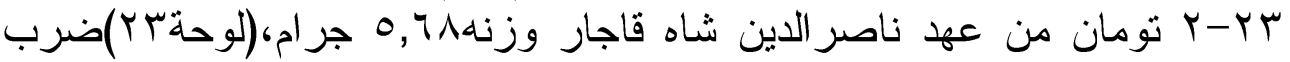

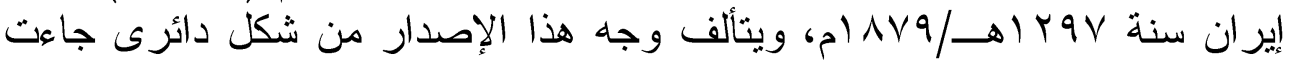

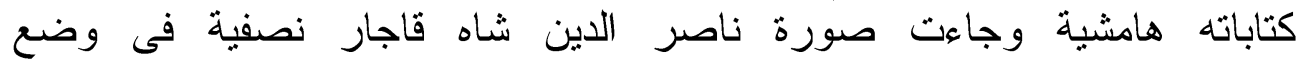
مواجهاهوهو يرتدى الطربوش الملكى، ونفذت الكاته الكتابات بالخط الفاه الفارسى ويحيط

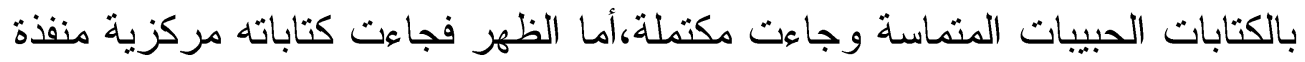

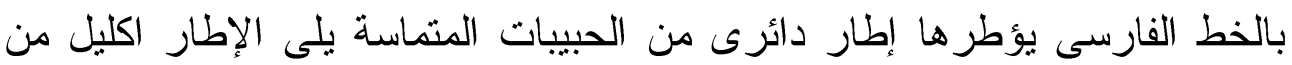

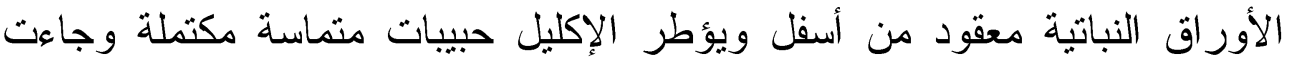

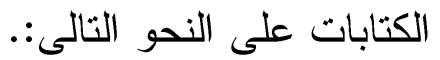

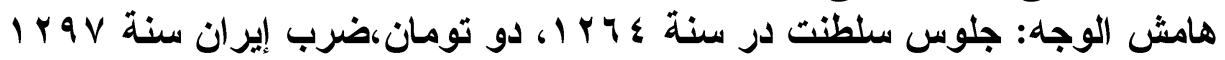

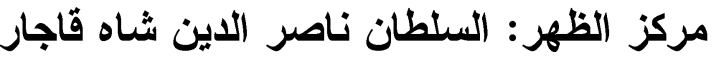

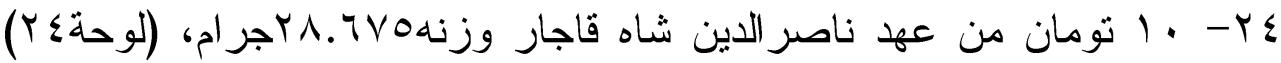

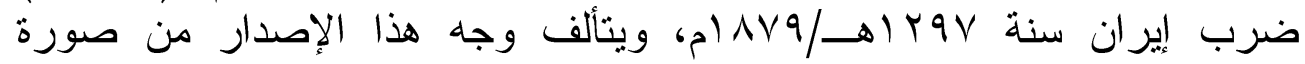

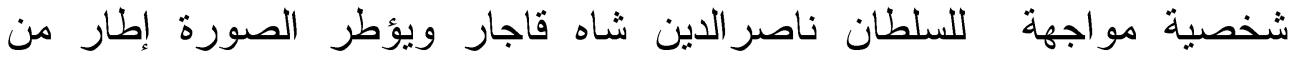

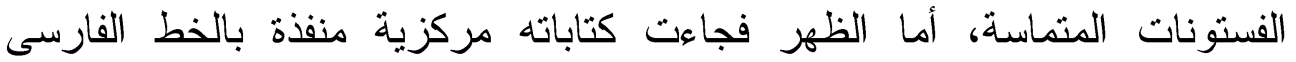

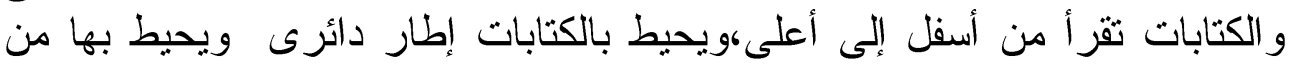

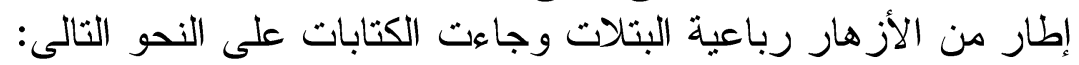

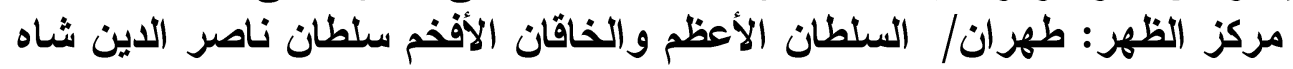

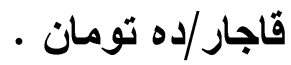

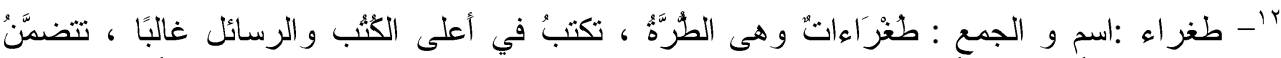

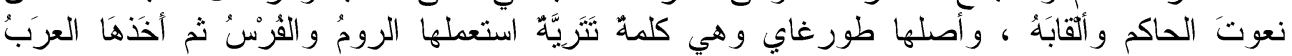

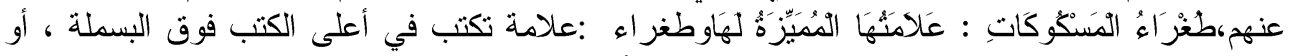

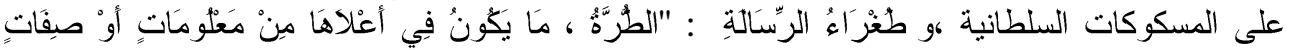

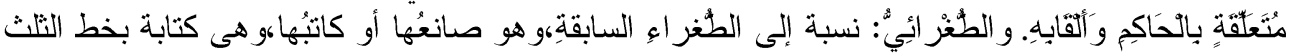

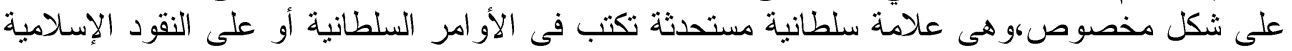

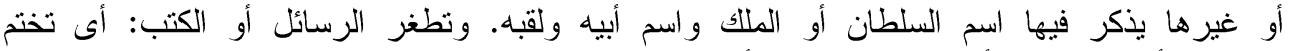

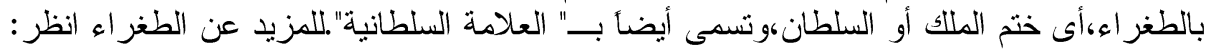

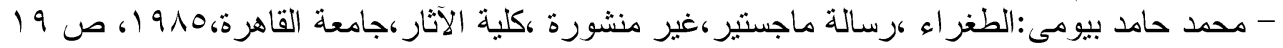

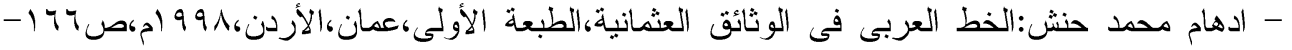
171 - عبده إبر اهيم أباظة: الطغر اء على النقود العثمانية، بحث منشور في كتاب مؤتمر الآثاريين العرب

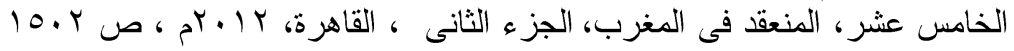




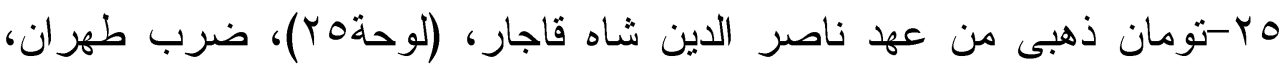

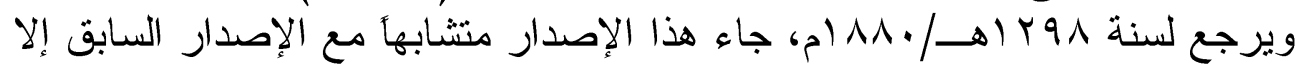

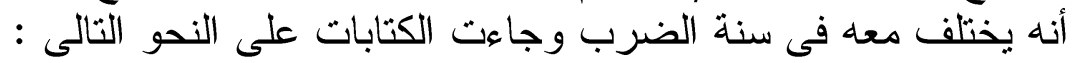

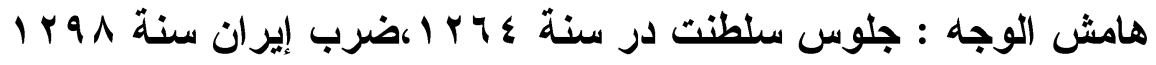

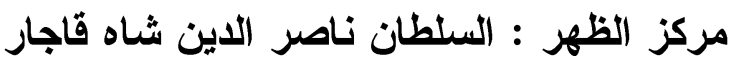

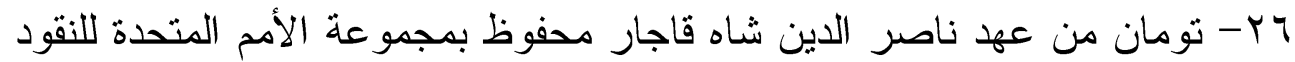

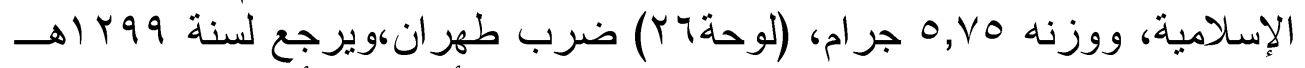

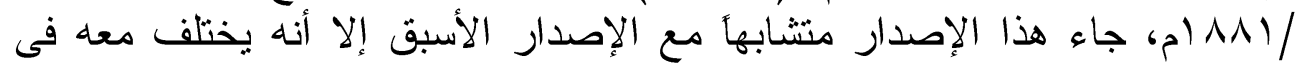

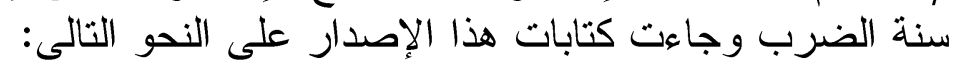

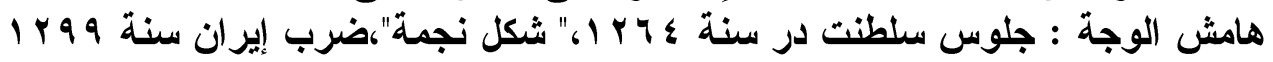

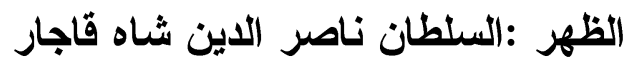

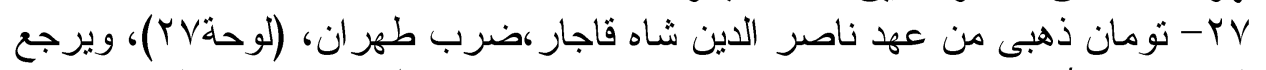

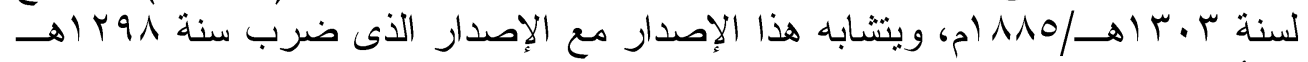

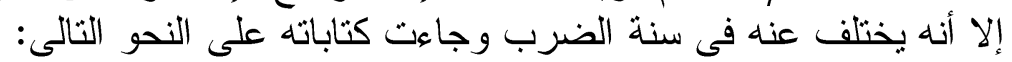

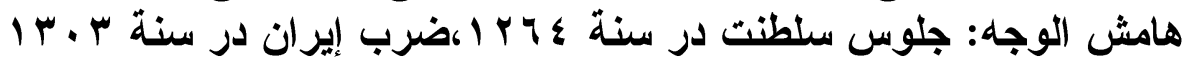

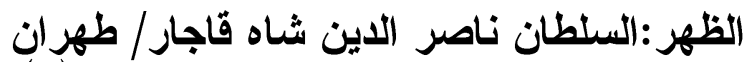

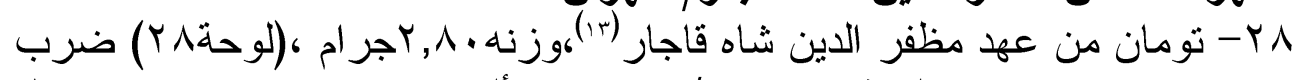

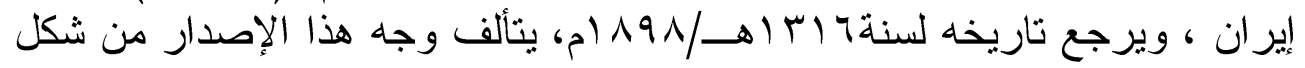

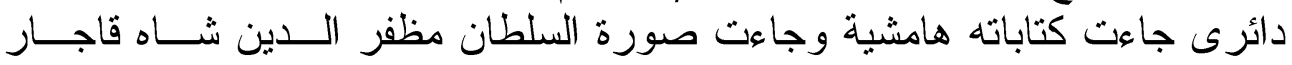

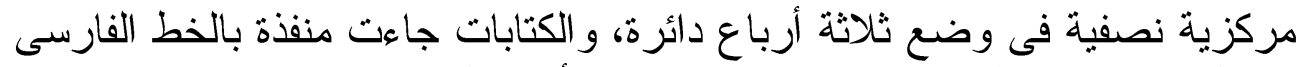

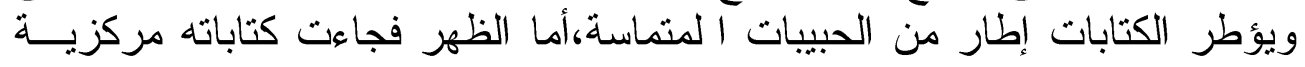

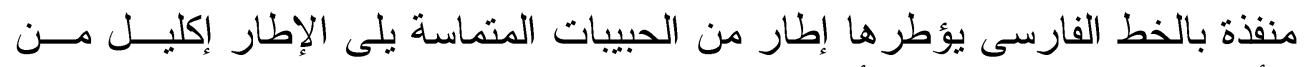

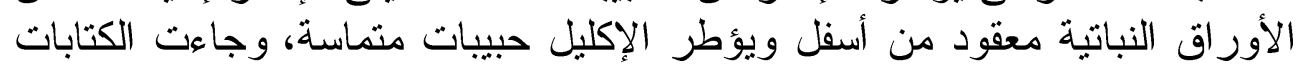

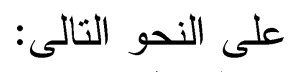

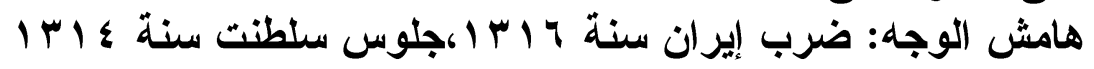

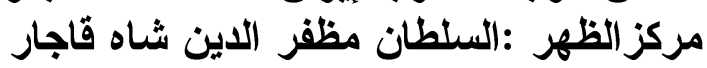

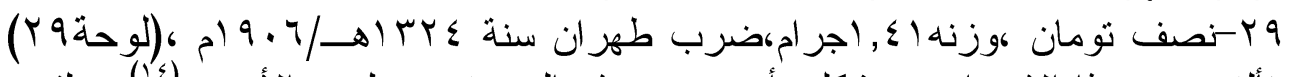

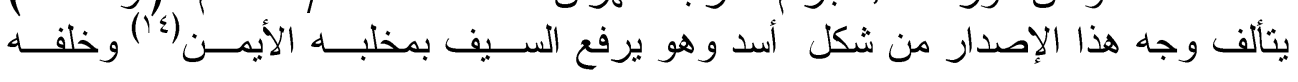

"'ا-'للمزيد عن تاريخ السلطان مظفر الدين انظر - Latifeh E.Hagigi :Qajar Royal Succession on the Case of Muzaffer Al din Mirza'Adiserrtation submitted to the faculty of the university of Uthan‘2012.

'أـ زخرفة الثمس المشع :ترتبط زخرفة الثمس المشعة بالعقائد الفكرية عند الثيعة ،فرمزية الزخرفة

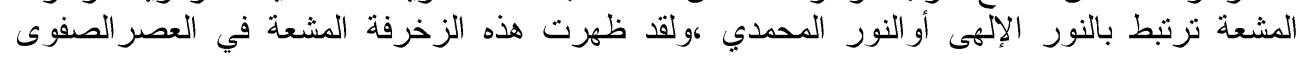

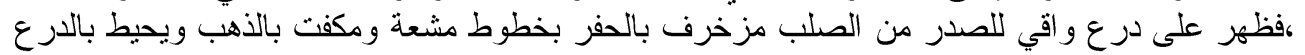

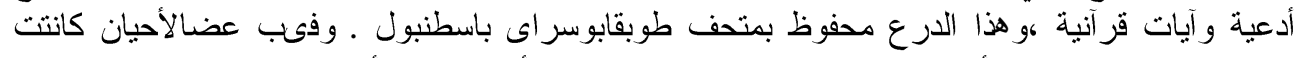

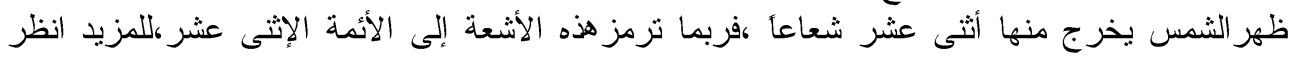




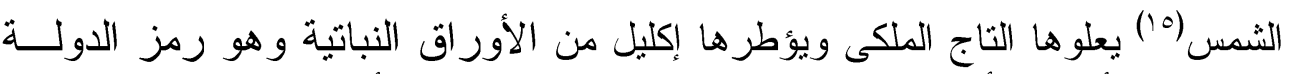

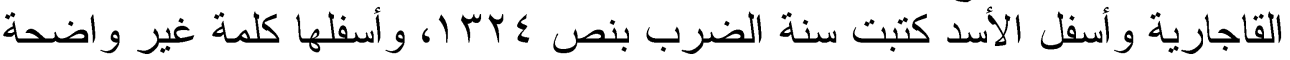

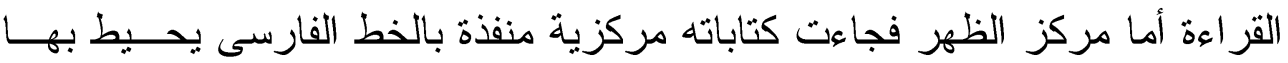

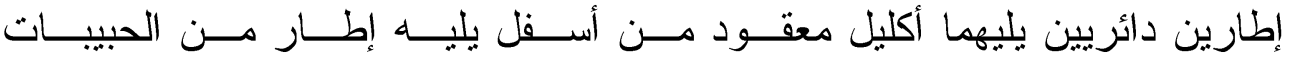
المتماسة،ووردت دائرين الكتابات كما يلئى

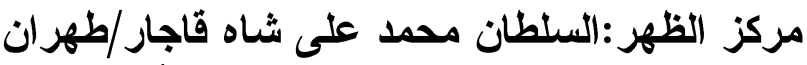

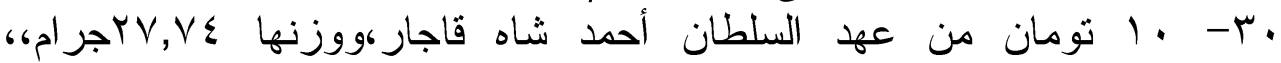

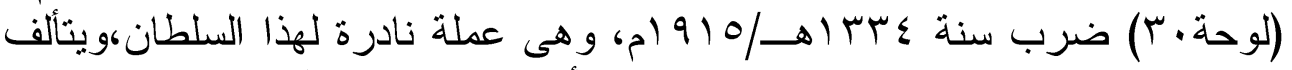

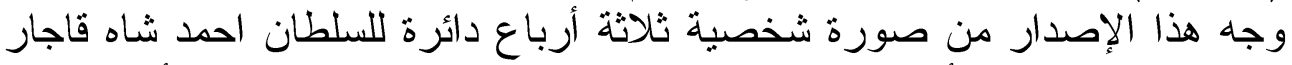

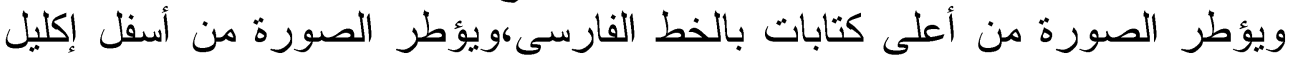

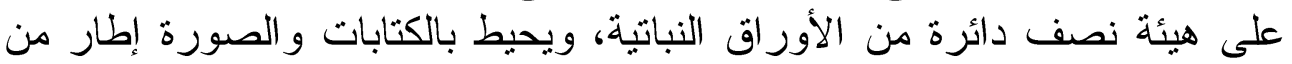

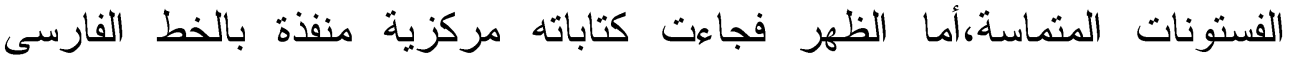

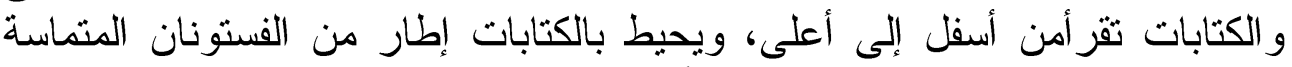
ويحيط بها من الخارج إكليل من الأوراق النباتية وجاءت الكنات الكتابات على النى النحو التالى

هامش الوجه:السلطان أحمد شاه قاجار شاهنشاه ايران

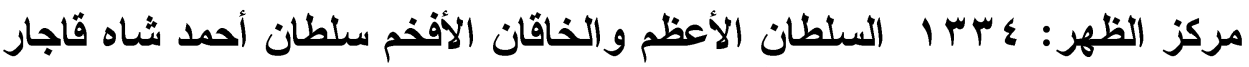

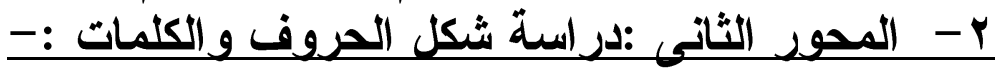

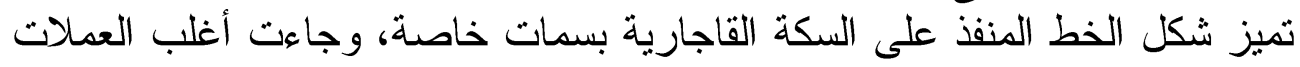

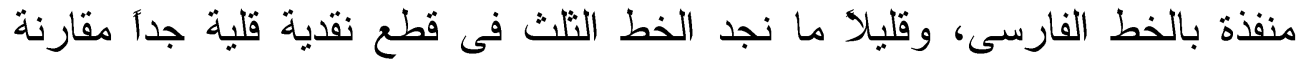

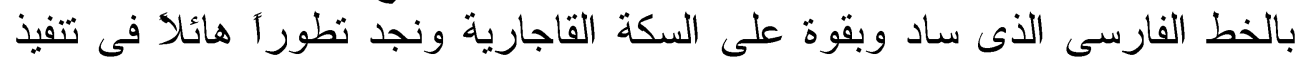

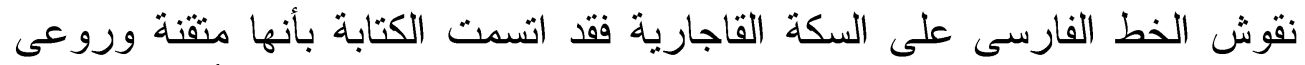
فيها النسبة الفاضلة في كتابات هذه العمالات النقدية وبالنسبة لتتفيذ أبجدية الكتابة التهابة

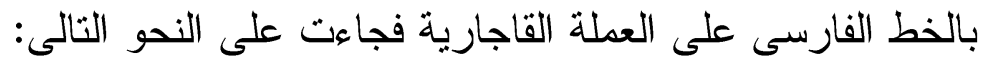
-

:مروة عمر محمد حسن المتولى: التصاوير الآدمية و الحيو انية على الخزف و المعادن و النقود القاجارية، ص • بروة 10 زخرفة الأسد: إن فكرة رفع الأسد للسيف بمخالبه منذ العصر القاجارى ،قد نفذت فى النقود القاجارية

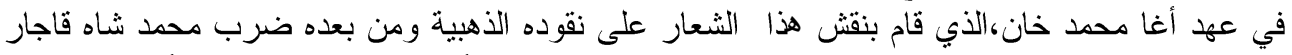

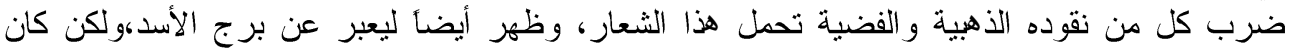

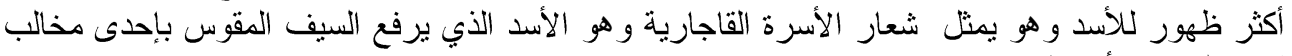
قدمه اليمنى الأمامية،

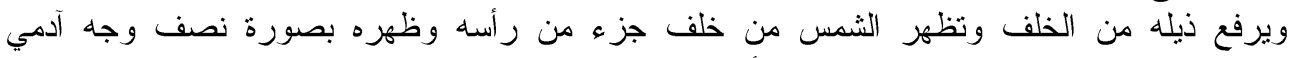

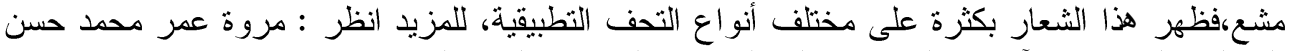

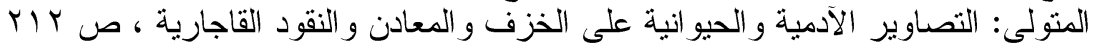


ورد حرف الألف بصورة مطلقة مسننة مشطوفة فى هامته وذنبه مدبب(7'أما بدنه

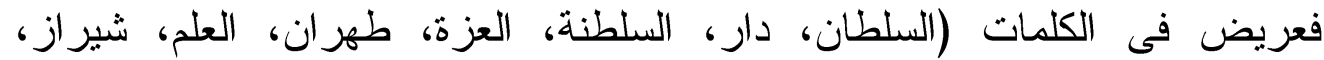

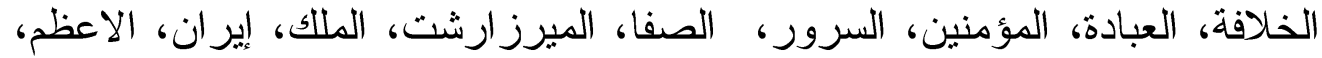

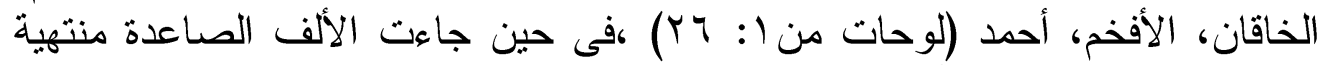
بدون تحريف مسنن فى أسفلها فى الكلمات (السلطان، العبادة، الصفا، الخاقان). - مرف الباه وأخوته:

جمعت الباء و أختها التاء المبتدأة فى الكلمات (بن،بلدة،بروجرد،ثبريز)هوجمعت الباء المتوسطة فى الكلمات (تبريز، طبرستان)، وجمعت الباء وأختها الثاء المنتهية المنصلة بالكلمات (ضرب، فئه ميرز ارشت، سلطنت).

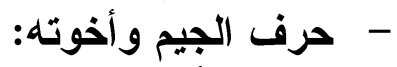

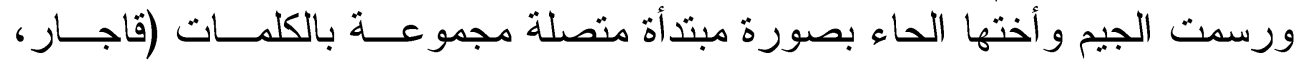

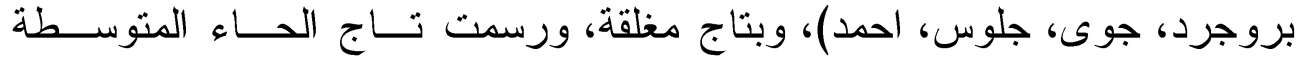

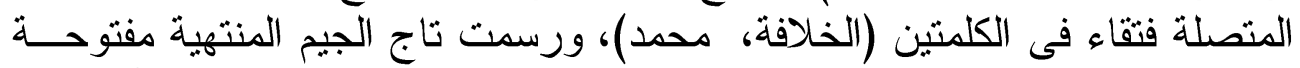

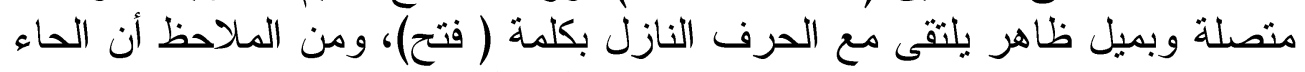

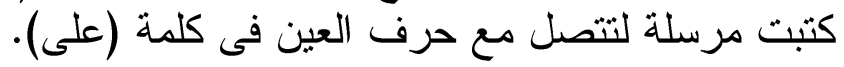

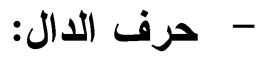

ورسمت الدال المفردة بعرض القلم فى جزئها المنكب،وبسن القلم فى خطها

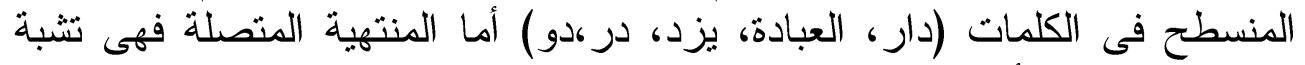
حرف الراء إلا أن معظم جسمها فوق خط التسطيح فى الكلمات (بلدة، الدين،

$$
\text { محمد، احمد). - مرف الر اء اء وأختها : }
$$

رسمت الر اء مفردة بدون جمع ولا ادغام على هيئة شبة مستقيمة أو بتقويس خفيف

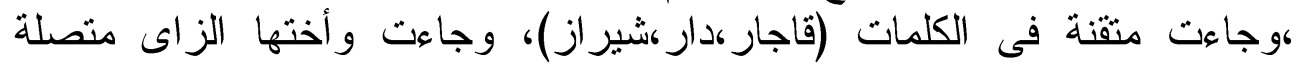
منتهية بثرفيع فى نهاية الحرف كما فى الكلمات (ضرب، فزوين، طهران، شيراز،

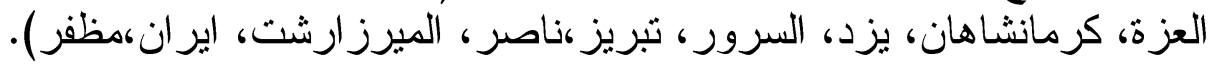

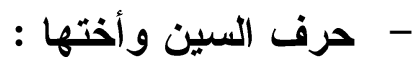

جاءت السين و أختها الثين مبتدأة معلقة مع كثيدة منوسطة فى الكمات (ســلــان،

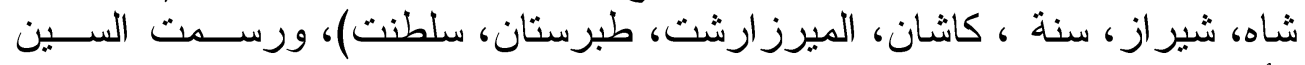

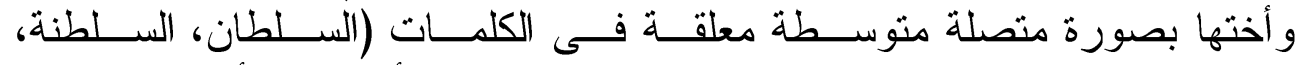

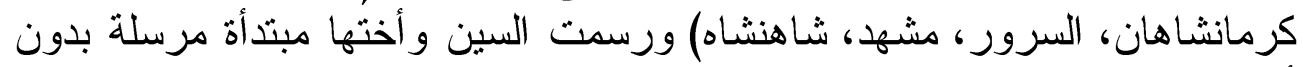

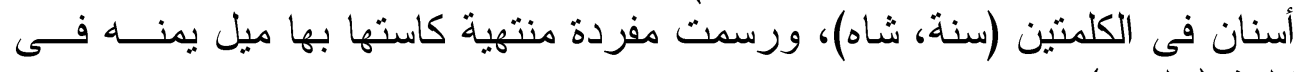
كلمة (جلوس)

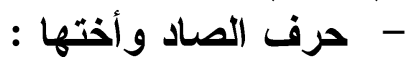

17 -استفدت من التحليل الأبجدى الذى أدرجه ا.د/ حسن نور فى بحثه عن شو اهد قبور عثمانية، مجلة كلية

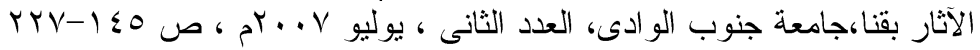


رسمث الصاد وأختها الضاد مبتدأة مرثفعة عن خط التسطبح بالكلمات (ضرب، ناصر) ، ورسمت متوسطة ملوزة فى كلمة (الصفا).

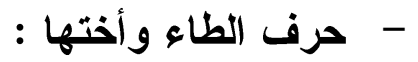

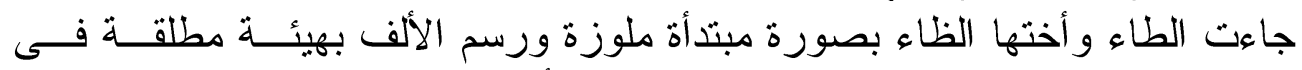

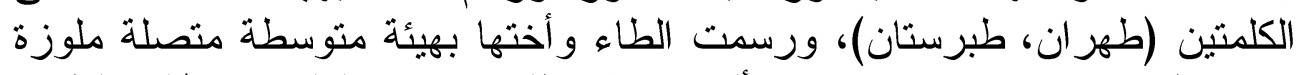

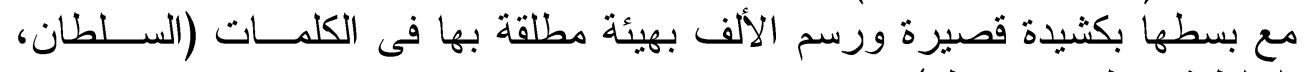

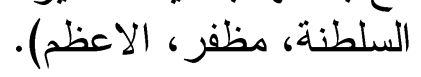

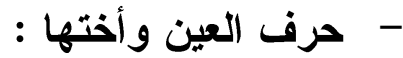

رسمت العين المبتدأة مفتوحة بفم متسع بيدأ بسن القلم فى الكلمات (على، الأعظم)، ورتقت العين المبتدأة على غير القاعدة باتصالها بكلمة "فتح" السابقة لها بكلمة (على)، وجاءت متوسطة مرثوقة مع كثيدة طويلة لضرورة شغل الفراغ فى فئ الكلمات (العلم، العبادة) .

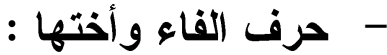

رسمث الفاء وأختها القاف مبتذأة متصلة مجموعة مطموسة فى الكلمات (فتح، قزوين، قاجار ، الخلافة ، الخاقان ،الأفخم)، فى حين رسمت مفتوفة مع عدم رسم

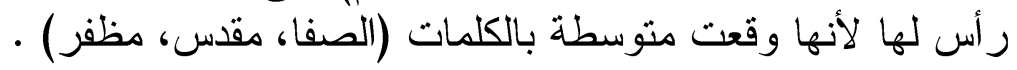

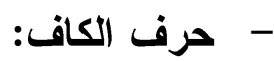

جاءت الكاف "ألفية"مجموعة سو اء أكانت مبتدأة أو منتهية بالكلمات (كرمانشاهان، كاشان، الملانك)

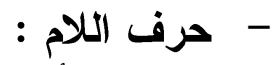

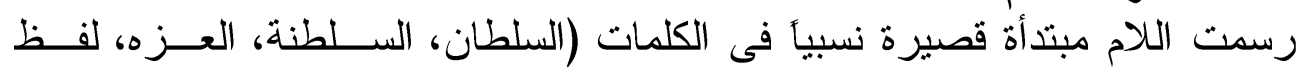

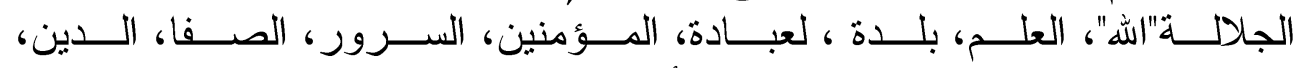

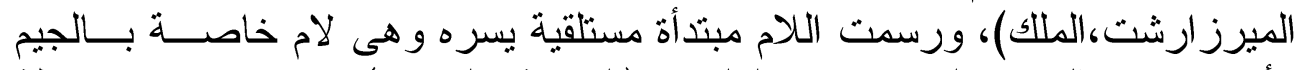

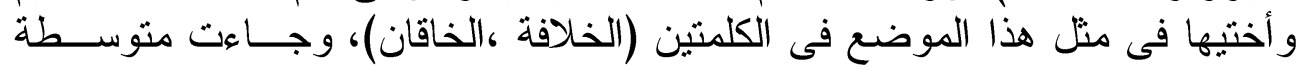

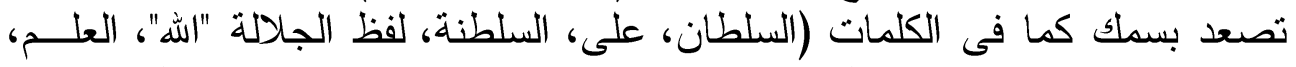

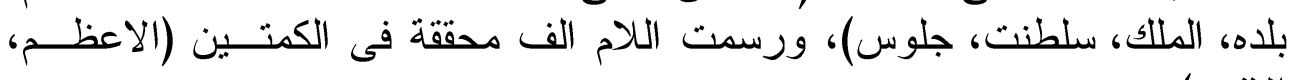
(الافخم)

\section{- -}

جاءت عقدة الميم المبتدأة مطموسة فى الكلمات (كرمان، مشهد، تومان، محمد)،

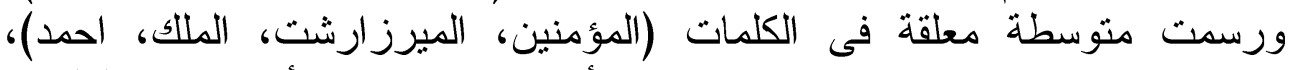
ورسمت منتهية مجرورة من تحت عقدتها أو من فوقها تارة أخرى فى الكلمثين

$$
\text { (الاعظلم، الأفخم). }
$$

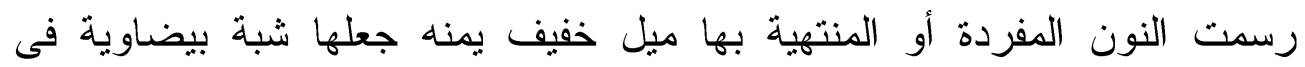

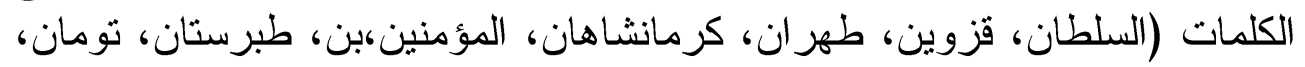
الدين، إيران)، ورسمث النون مجموعة فى كلمة (ناصر)، وجاءت النون المتوسطة 
بهيئة قائم قصير مائل يمنه ثم يلتقى بخط التسطيح فى الكلمات (السلطنة، المؤمنين،

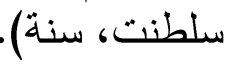

\section{-}

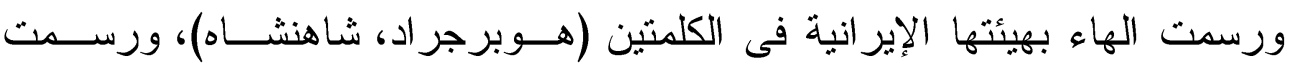

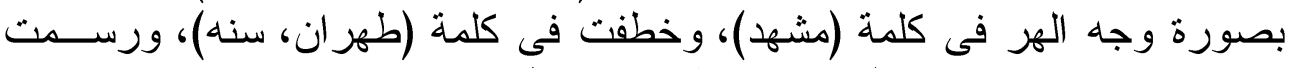

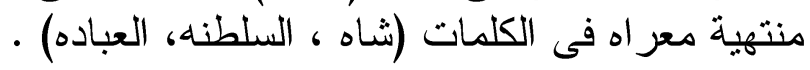

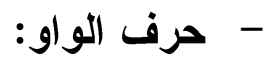

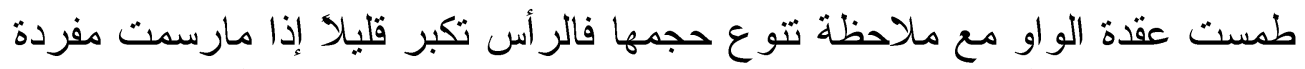

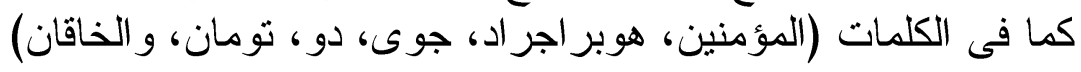
-

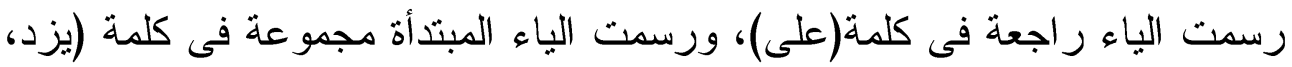
إير ان)، ورسمت منوسطة منصلة مجموعة فئى في الكلمات (تبريز ، المؤمنين).

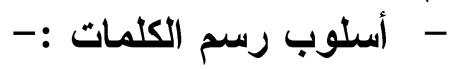

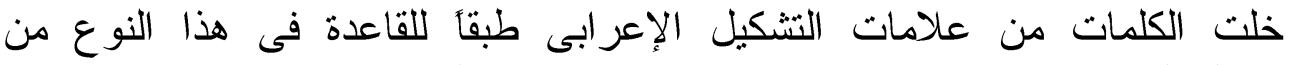

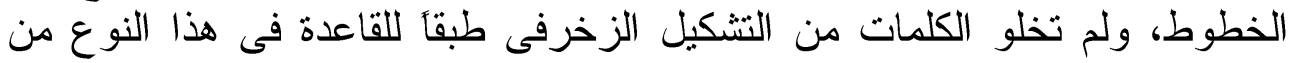

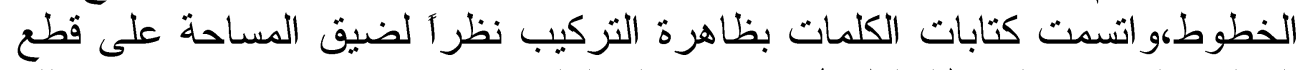

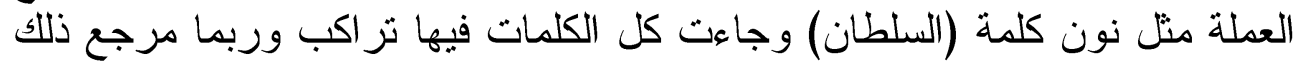
إلى كون قطعة العملة دائرية الثكل، الثلة الإعجام جاء دقيقاً بكل الكلمات.

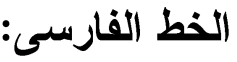

كان لانتشار الإسلام فى فارس أثز كبير فيها،فعلى الرغم من تعصب

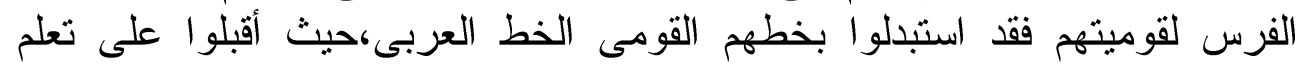

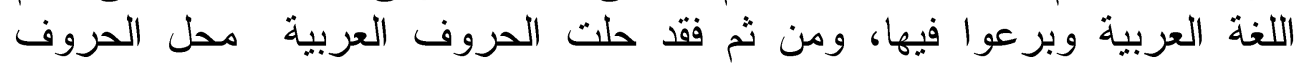

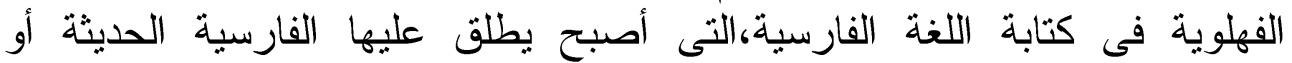

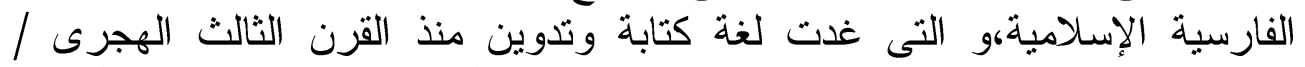

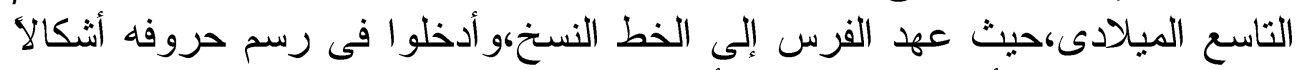

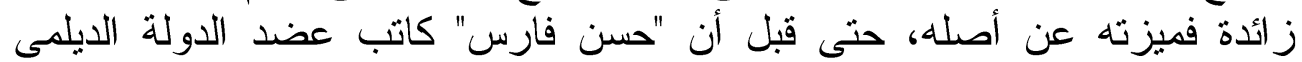

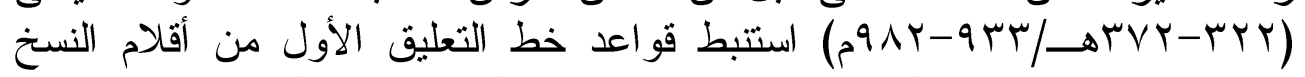

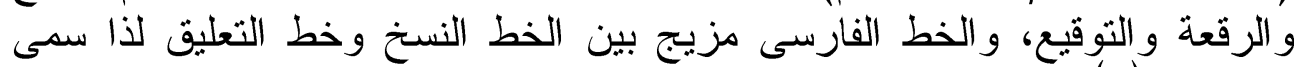
بالنستعليق (1v)

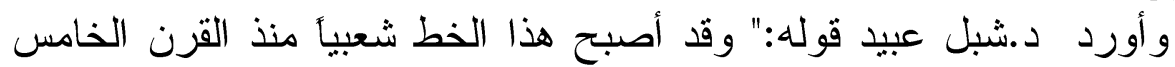

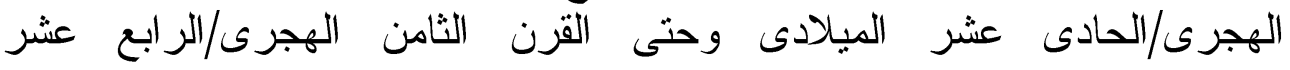

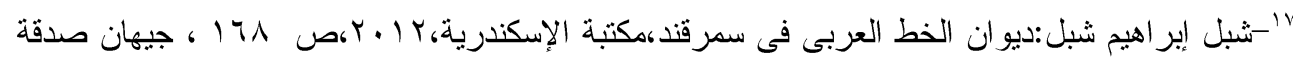

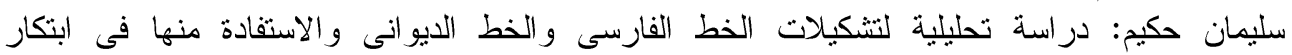

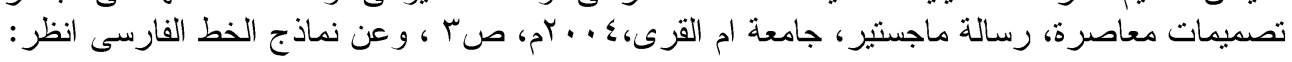
Annemarie Schimmel:calligraphy and islamic culture,London,1990,p 76 
الميلادى،وخلال القرن السابع الهجرى/الثالث عشر الميلادى انبثقت عنه أشكال

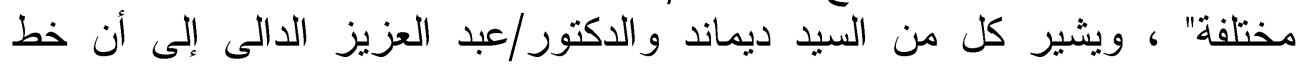

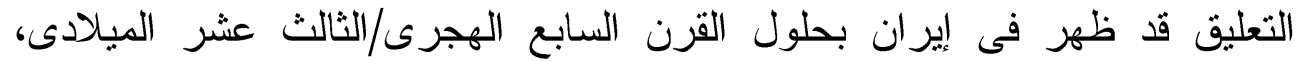

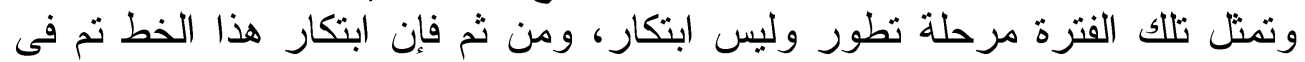

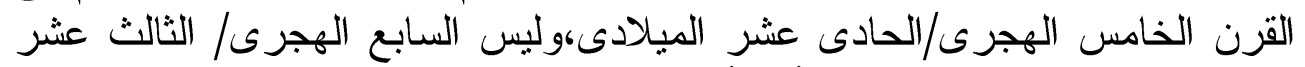

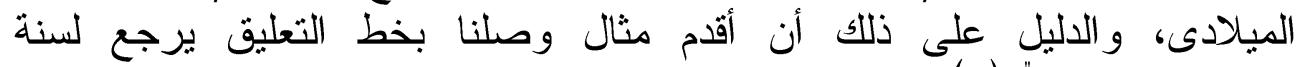

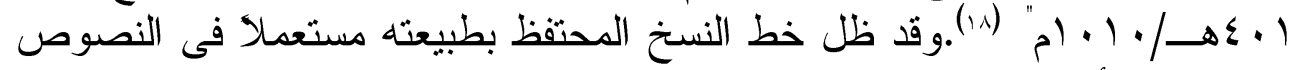

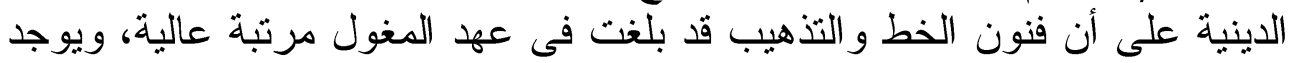

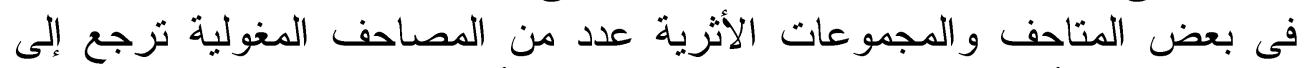

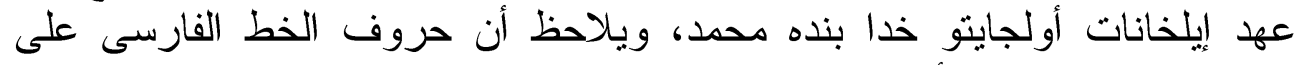

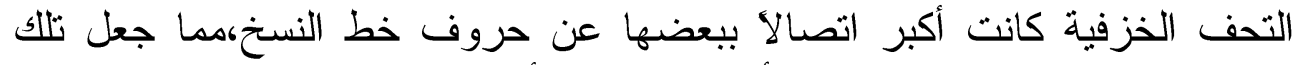

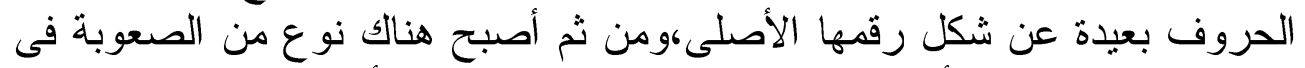

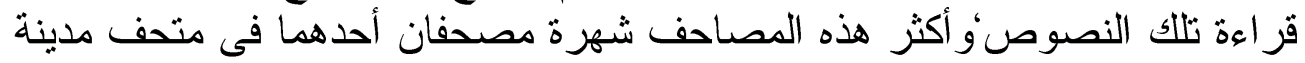

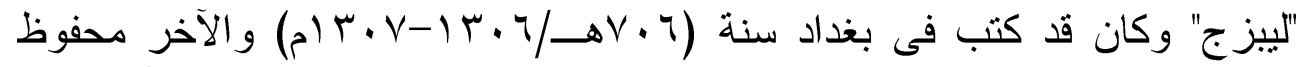

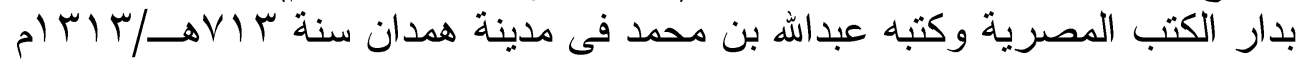

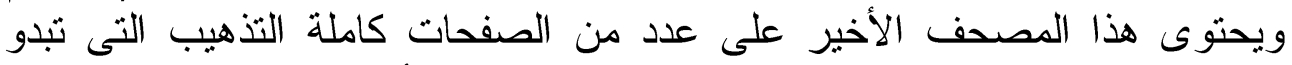

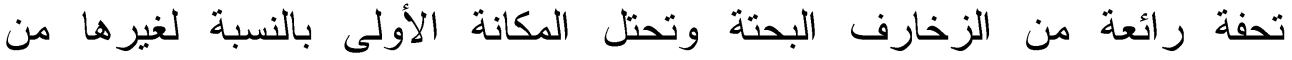

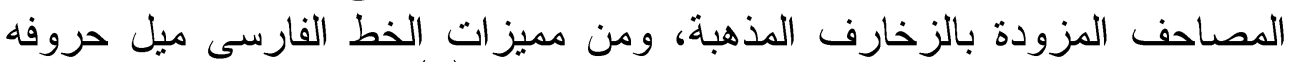

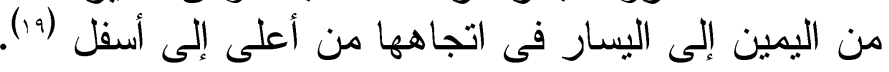

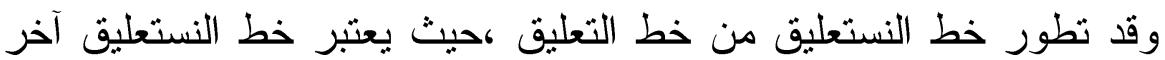

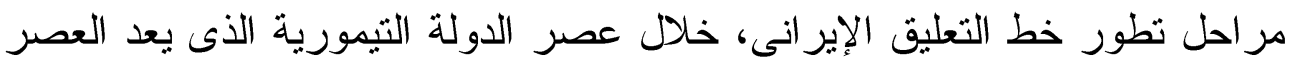

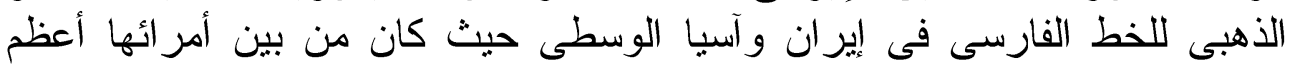

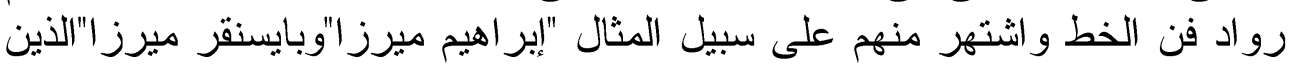

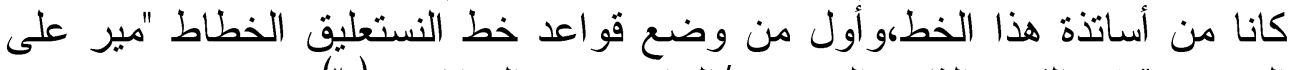

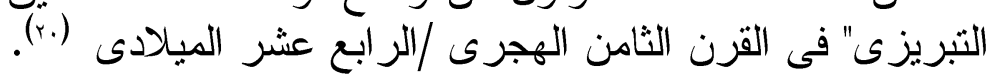
خط الثلث:

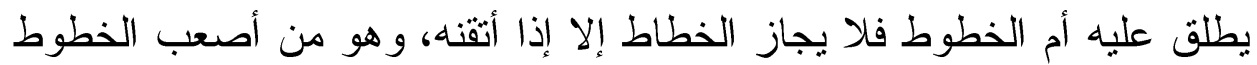

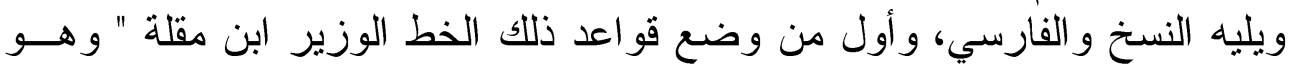

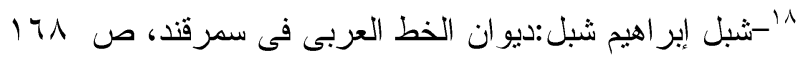

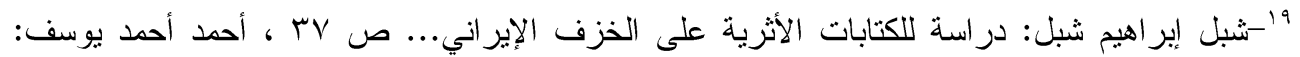

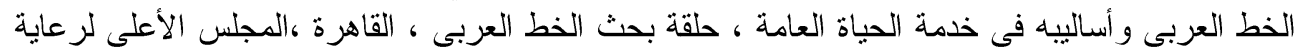

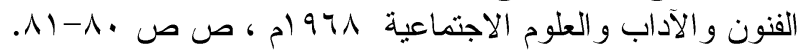

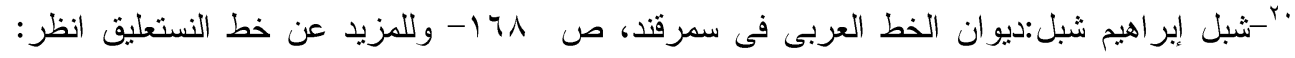
نصار محمد منصور وآخرون : خط النستعليق الجذور التاريخية والخصائص الفئية فئنية ،المجلة الأردنية

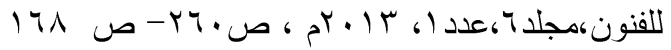


نوعان الثلث الخفيف والثلث الثقيل وتسمية التلث بهذا الاسم ما في معناه من الأقلام

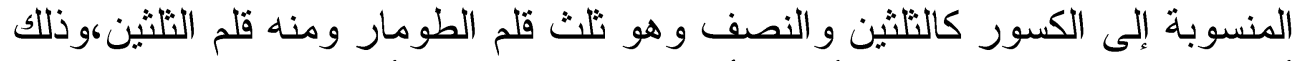

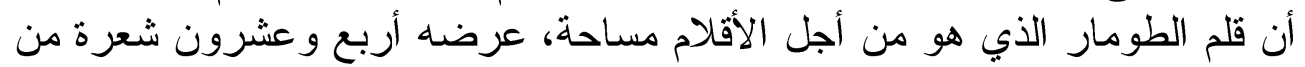

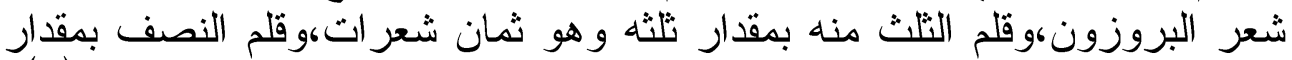

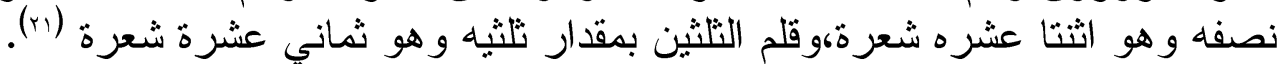

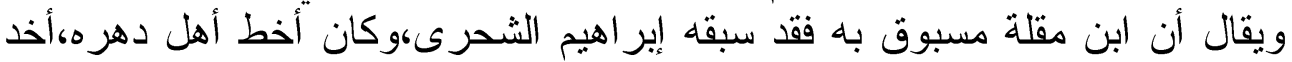

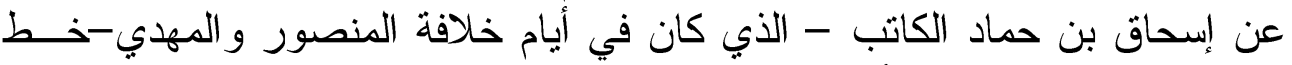

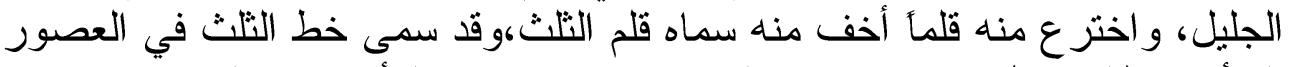

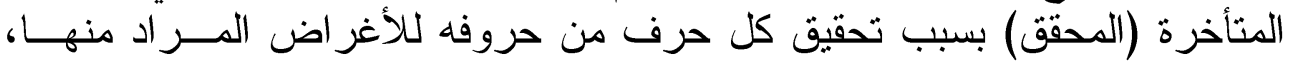

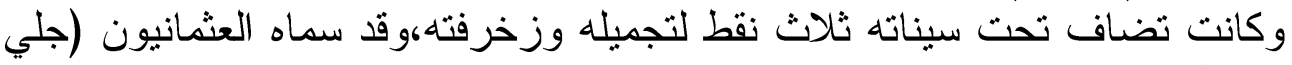

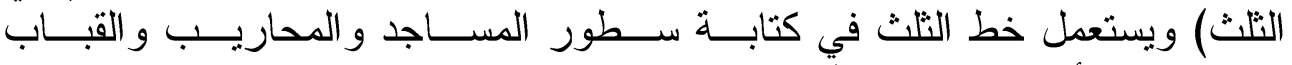

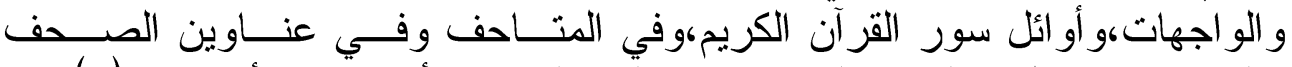

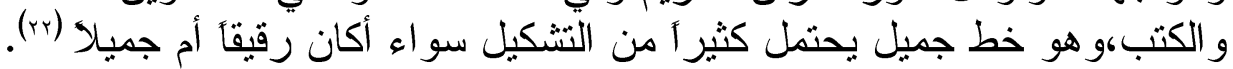

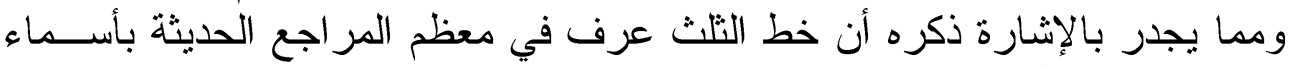

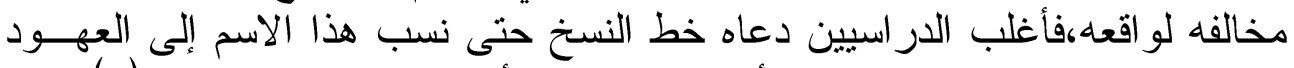

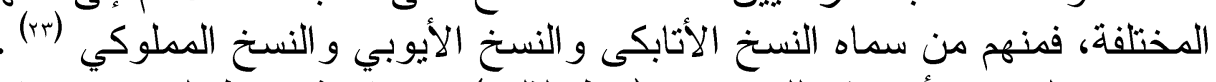

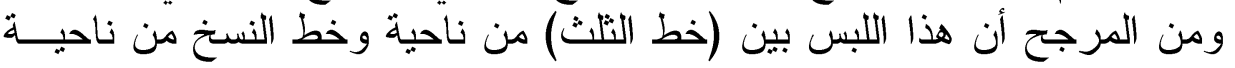

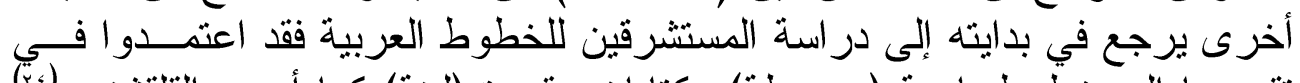

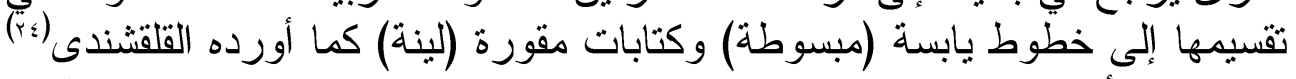

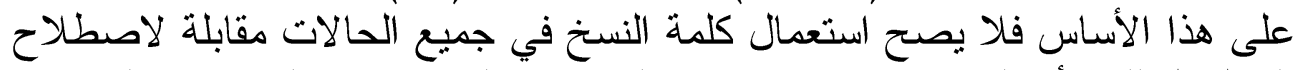

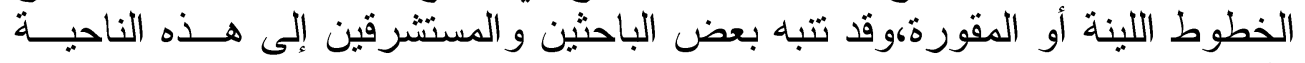

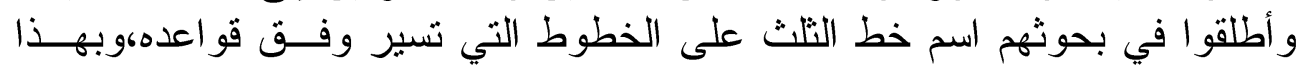

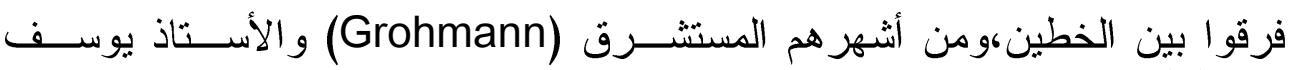
ذنون (ro) ف المن

اب- يحيى و هيب الجبورى: الخطو والكتابة في الحضارة العربية ، دار الغرب الاسلامي ، الطبعة الاولى ،

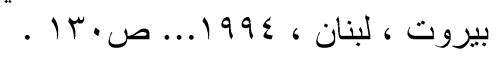

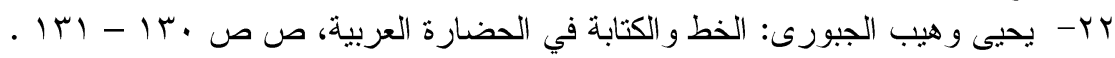
Annemarues Schimmel, Calligrapgy And Islamic Culture, London. 1990, P.20.

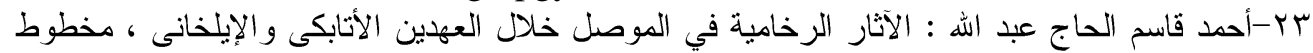

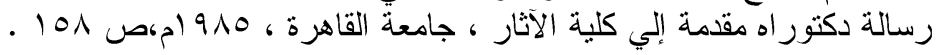

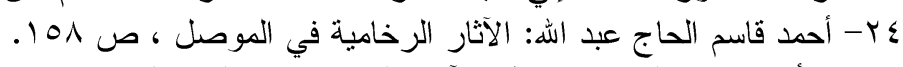

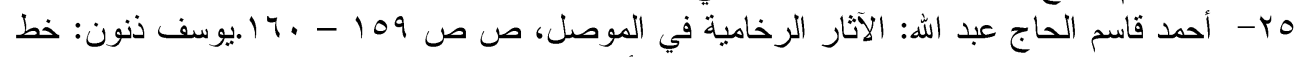

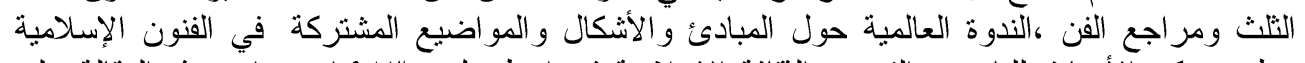

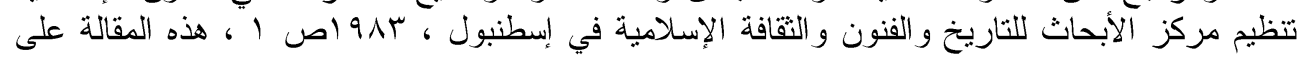
هذا الز ابط مركز الان 


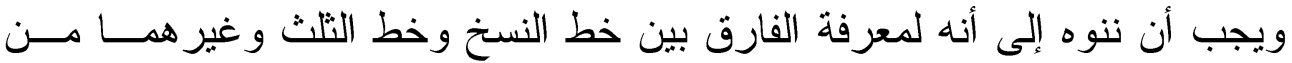

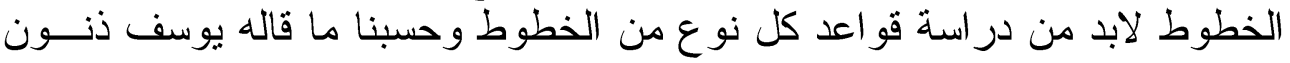

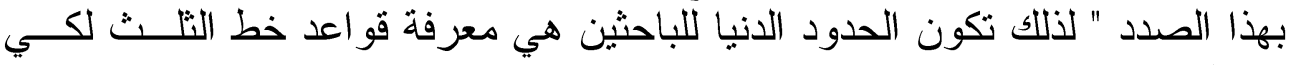

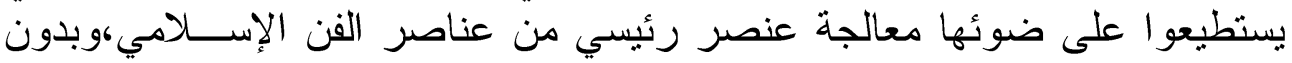

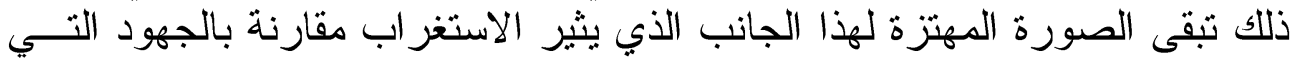

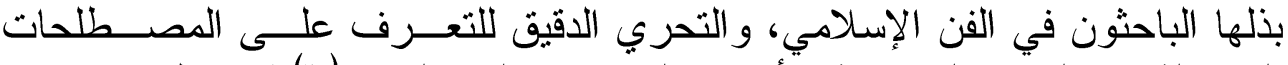

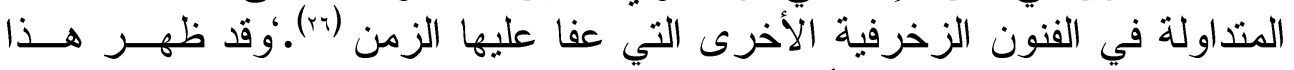

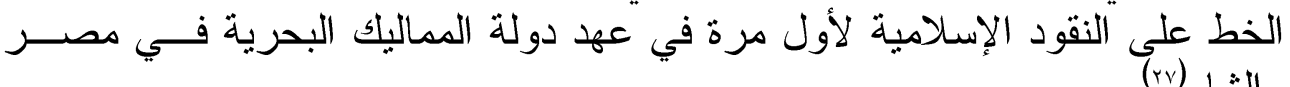

\section{المحور الثالث: -در اسة مضمون السكة القاجارية}

تضمنت النقوش الكتابية المنفذة على نماذج من السكة القاجارية على العنى العديد من

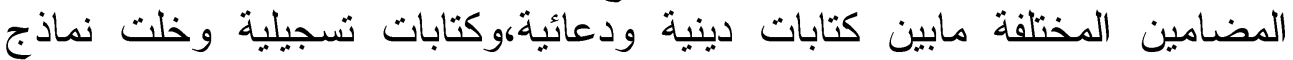

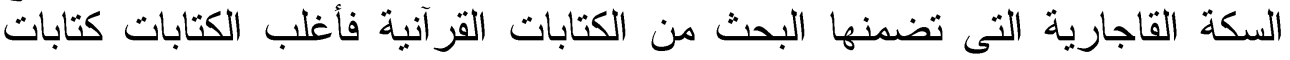

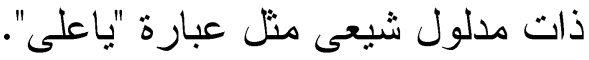

$$
\begin{aligned}
& \text { الكتابات الاينية : } \\
& \text { : با على : }
\end{aligned}
$$

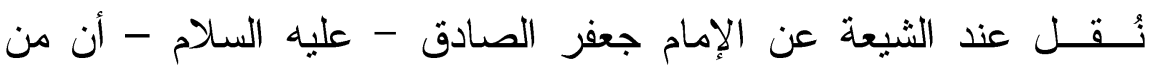

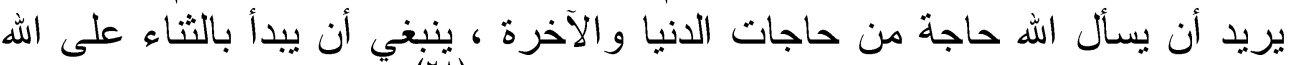

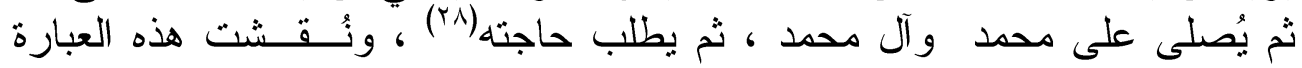

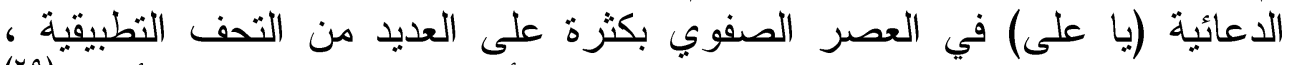

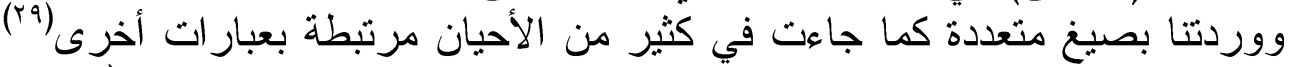

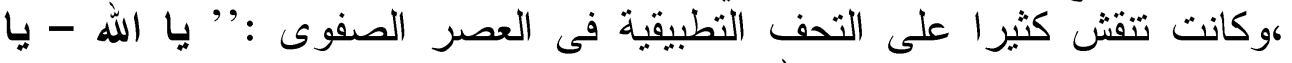

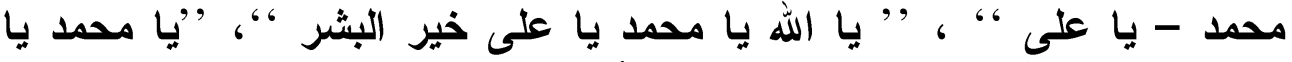

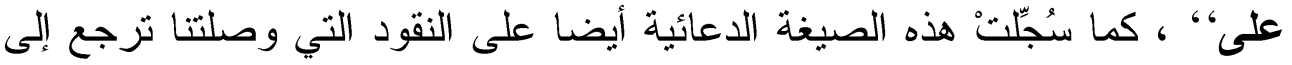

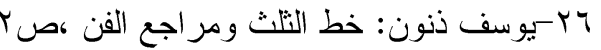

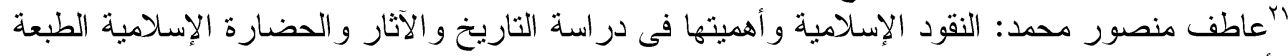

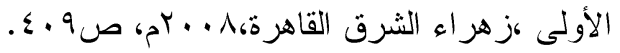

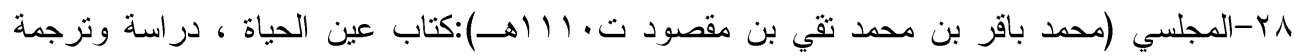

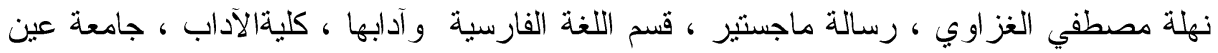

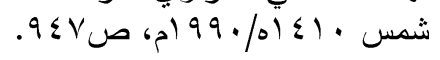

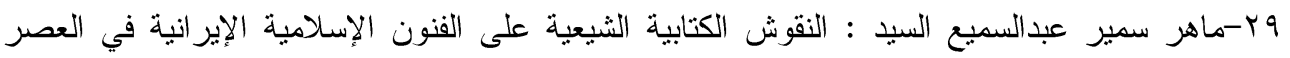

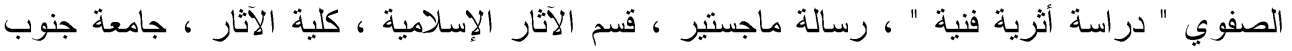

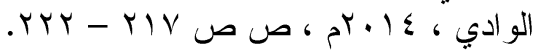




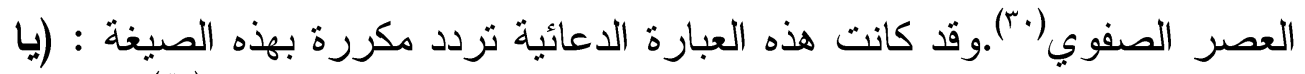

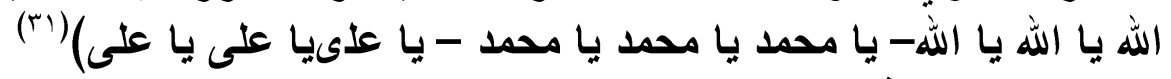
الكتابات التسجيلية الهابة

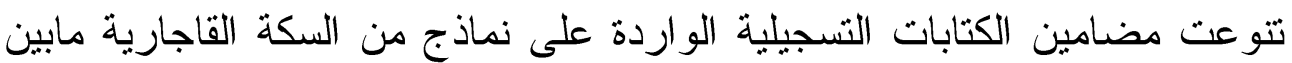

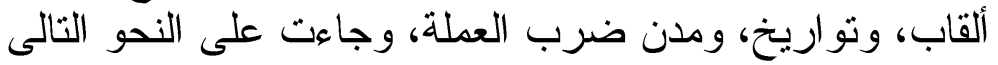

$$
\text { - أ- الألقاب: }
$$

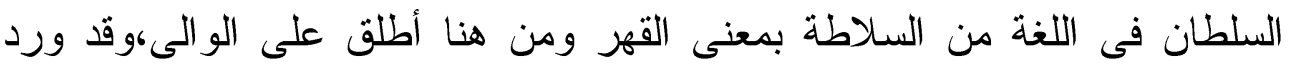

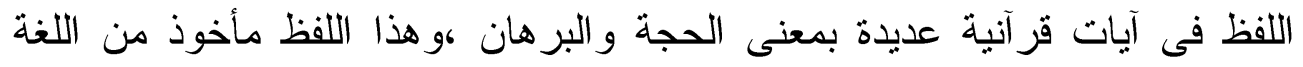

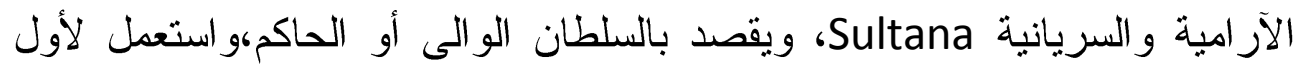

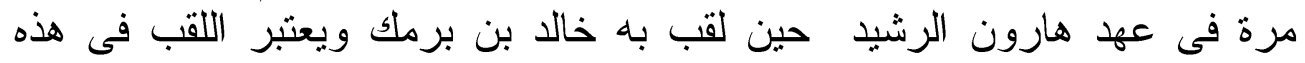

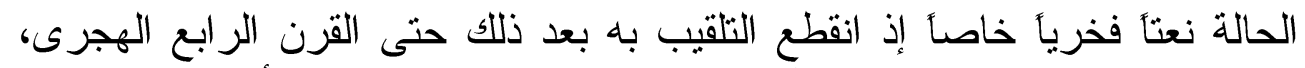

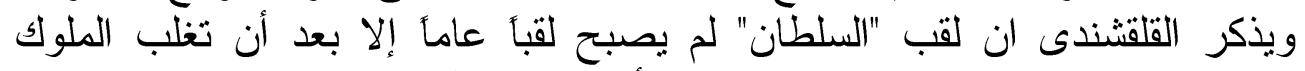

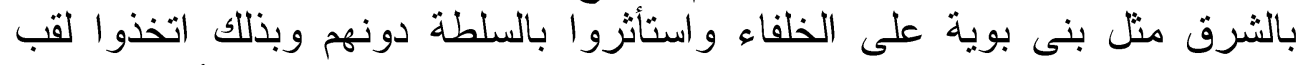
"السلطان" سمة عامة لهم فضلا عما كان بضفيه عليهم الخليفة من ألقاب فخرية

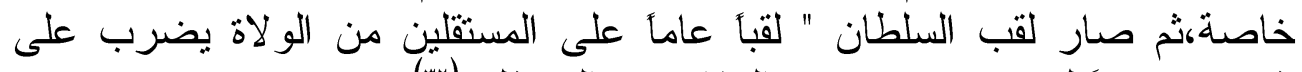

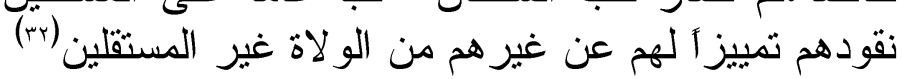

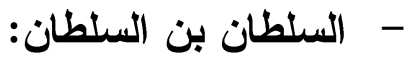

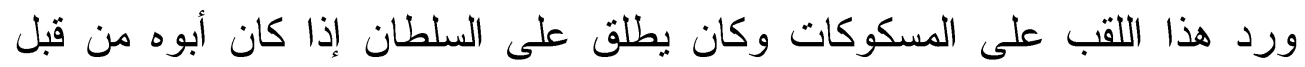

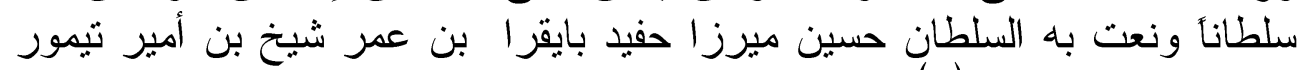

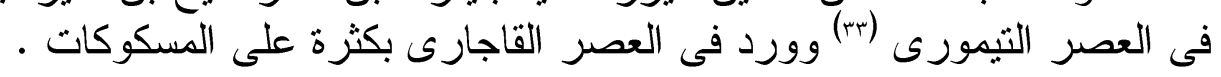

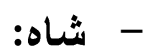

لفظ فارسى بمعنى ملك أو سيد،وكان بطلق على ملوك الفرس أومن تشبه بهم، وقد الفّان

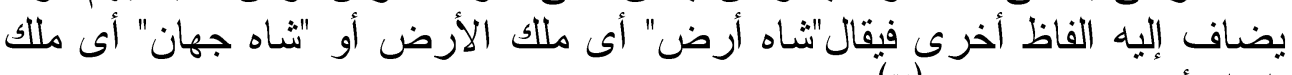

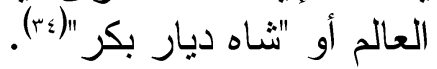

• ب-ووردت هذه الصيغة الدعائية (بامحد - ياعلى) أيضا على عملة فضية من ضرب أصفهان ،

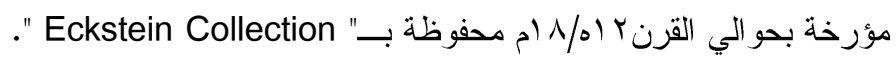
Luschey - Schmeisser : The Pictorial Tile Cycle of Hast Behest in Isfahan and Icono Graphic Tradition, Vol.XIV,Ismeo - Rome, , 1978 ,Pl.LXIX, Fig.127.

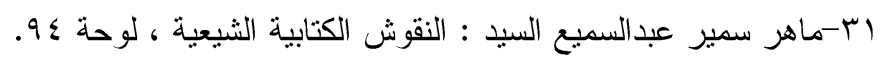

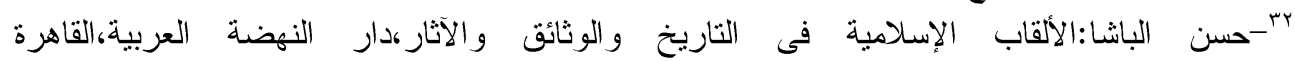

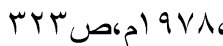

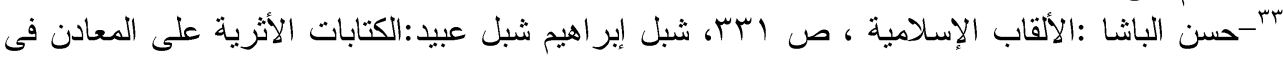

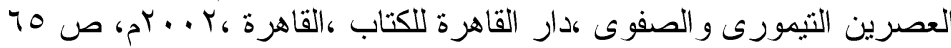

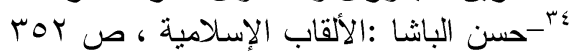


لقب فارسى مختص بملك الملوك عند الفرس وذللك تمييزأ لله عن لقب "شاه"فقط

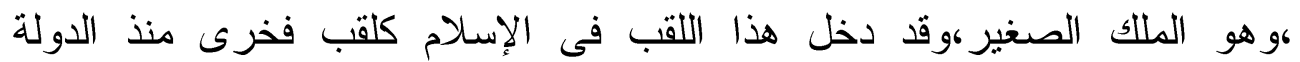

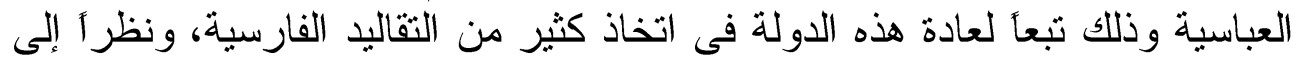

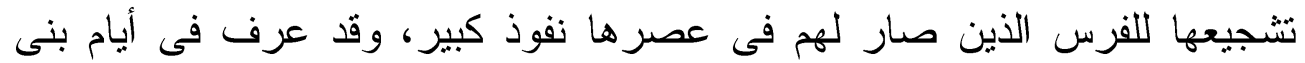

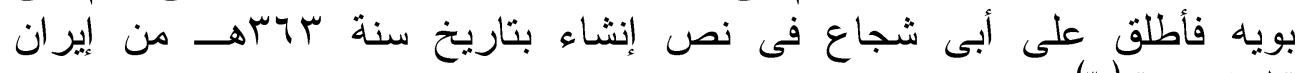

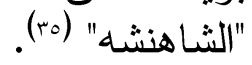

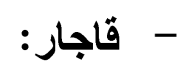

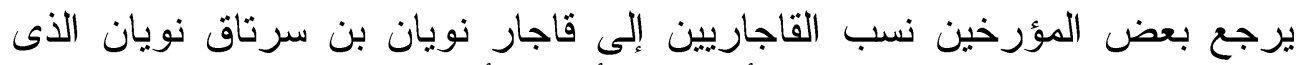

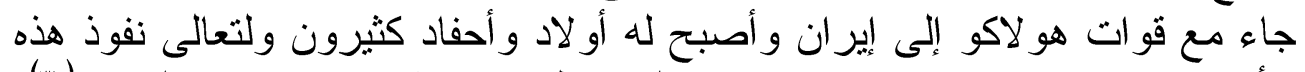

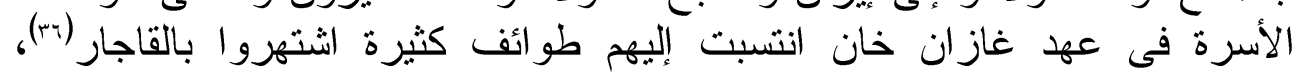

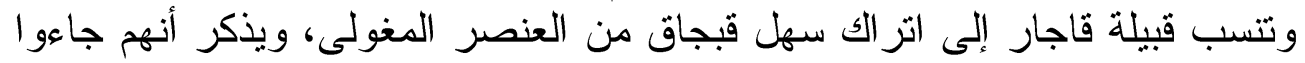

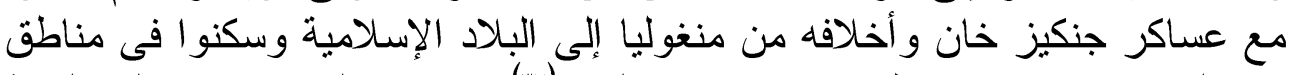

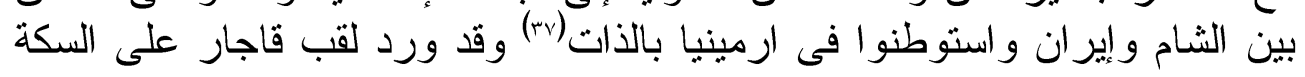

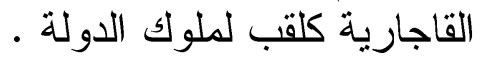

\section{ب-التواريخ : باربخ}

سجلت التواريخ على السكة القاجارية بطريقة واحدة فقط وهى تسجيل التاريخ

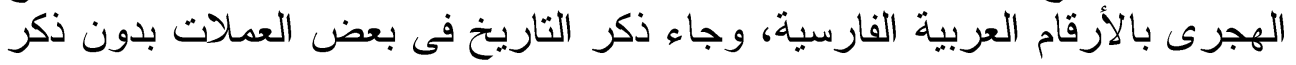

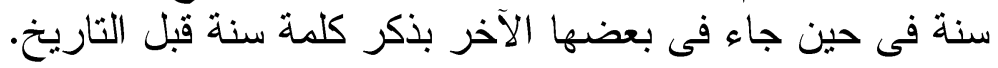
ج- مدن الضرب:

اتسمت سكة القاجار بتعدد مدن الضرب الضرب التى ضربت فيت فيها هذه السكة،وقد وردت

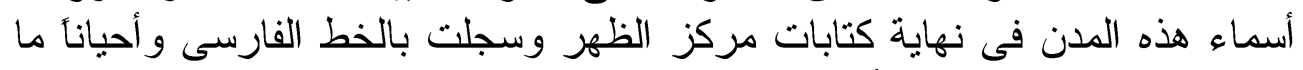

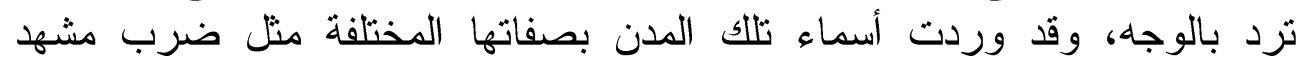

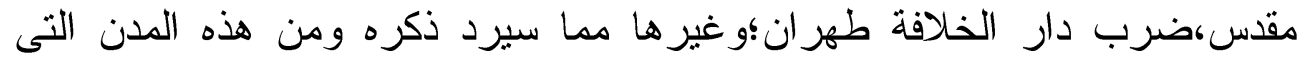

$$
\text { وردت ما يلى : تبريز : }
$$

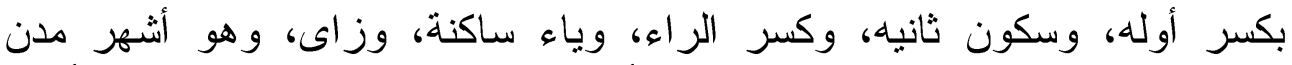

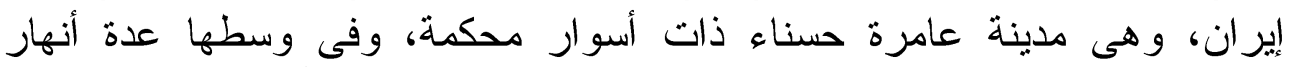

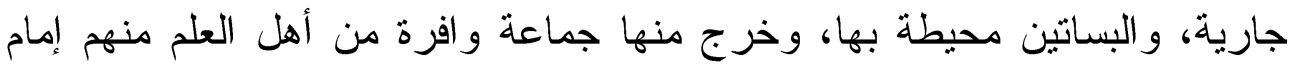

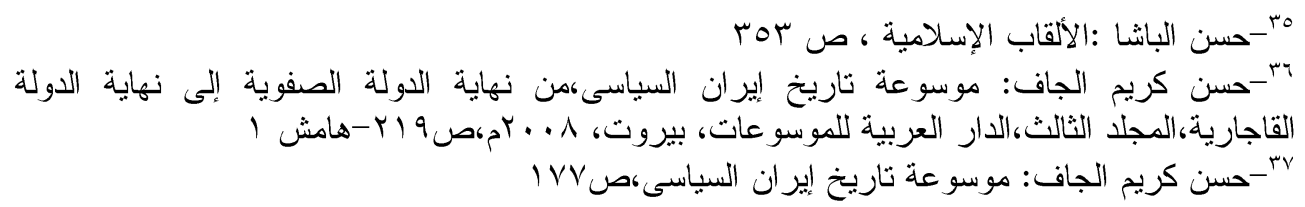




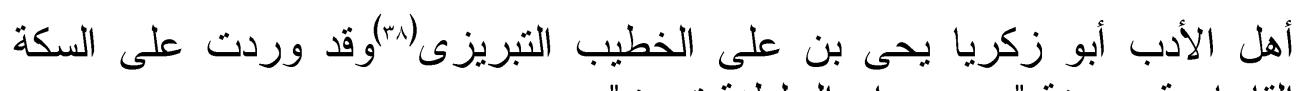

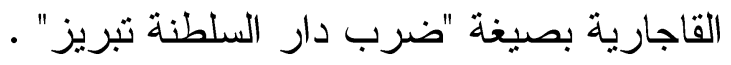

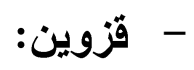

قزوين بالفتح ثم السكون وكسر الواو وياء مثناه من تحت ساكنه ونون،مدينة

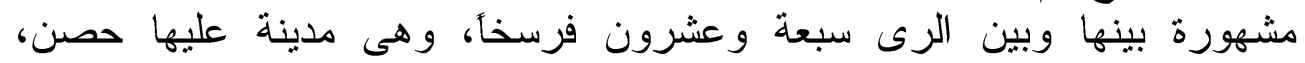

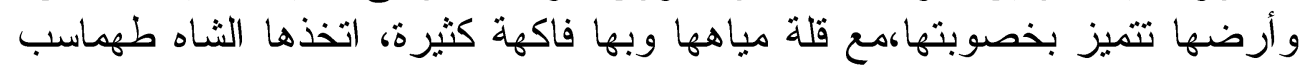
عاصمة للاولة الصفوية حتى تكون بعيدة عن الجيوش العثمانية، وظلت فياهية قزوين

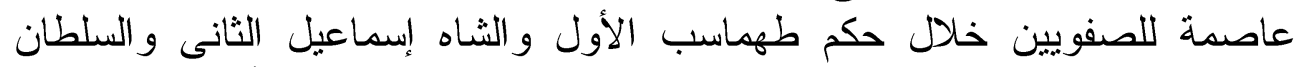

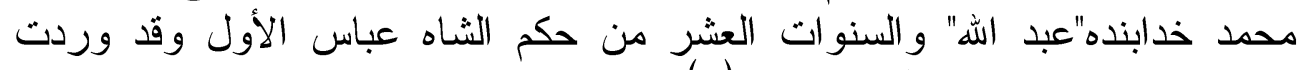

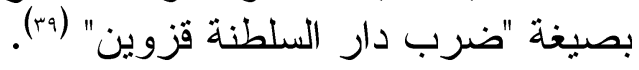

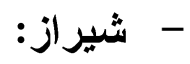

بلد معروف ومشهور وهى قصبة بالاد فارس فى الاقليم الثالث وتقع وسط إيران،

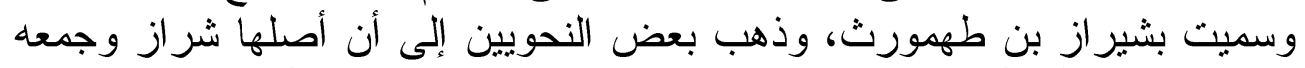

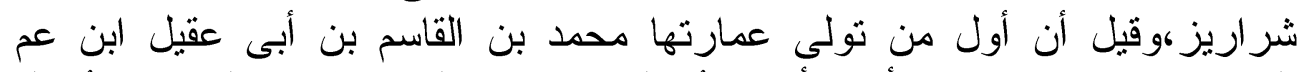

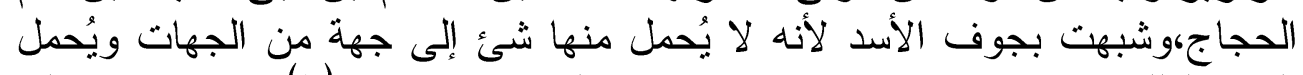

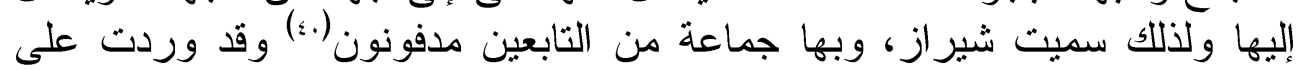

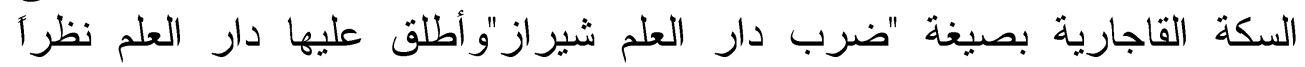

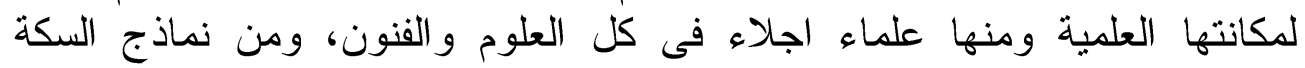

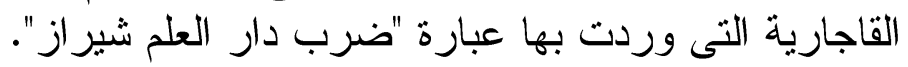
-

طهر ان بالكسر ثم السكون، ور اء، و آخره نون، وهى كلمة أعجمية،وهى من قرى ورى

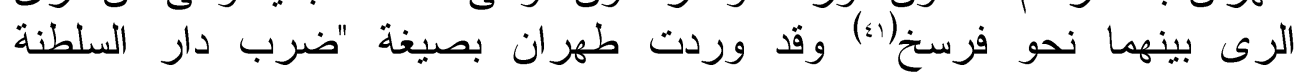

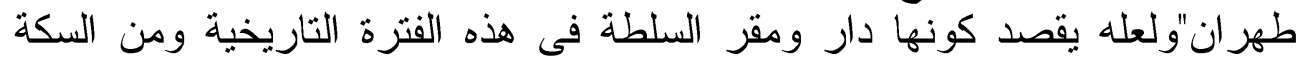

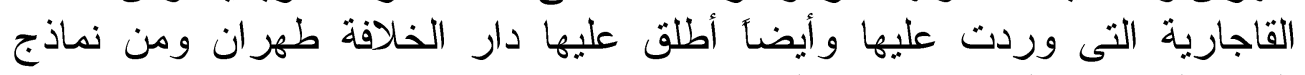

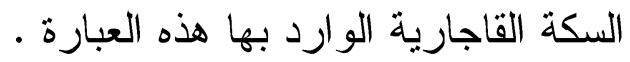
-

يَّ- ياقوت الحموى الشيخ الإمام شهاب الدين أبى عبد الله ياقوت بن عبد الله الحموى الرومى البغدادى-

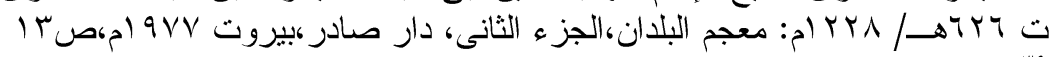

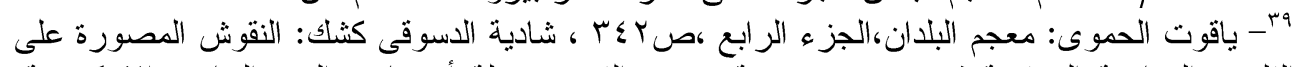

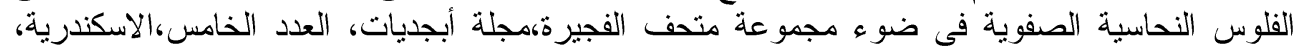

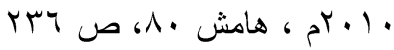

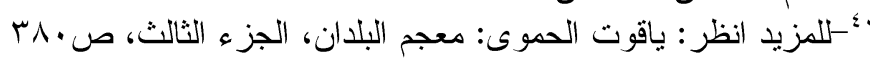

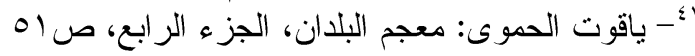


هى ولاية مشهورة بين فارس ومكران وسجستان وخر اسان، وهى بلاند كثيرة

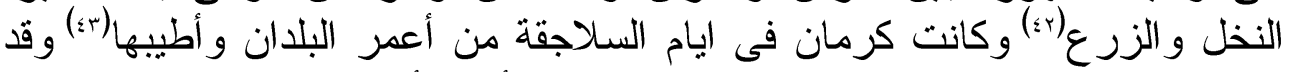

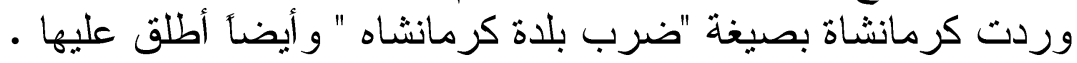

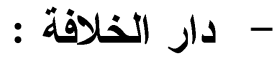

وقد استعملت لفظة"دار الخلافة"في الدولة العثمانية في عهد السلطان سليم الأول بن بايزيد الثاني (11)

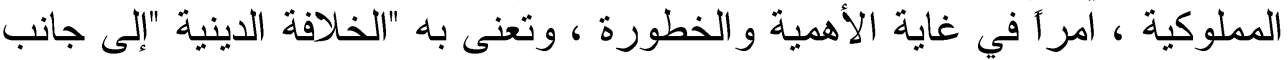

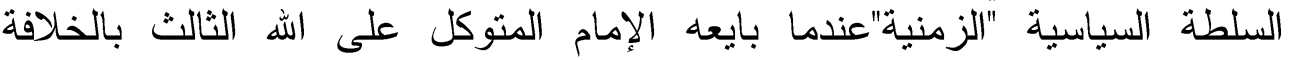

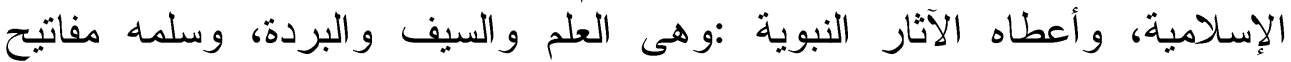

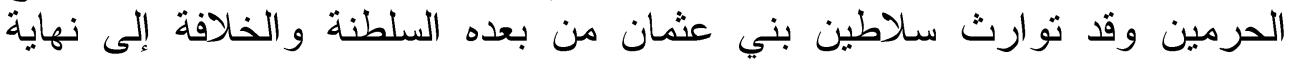

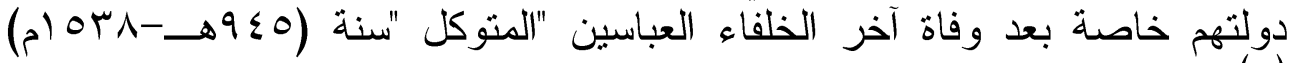
(ई

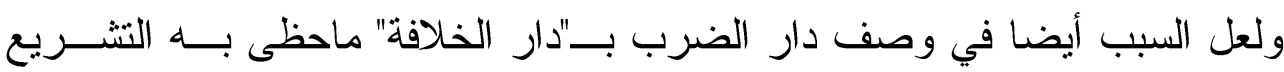

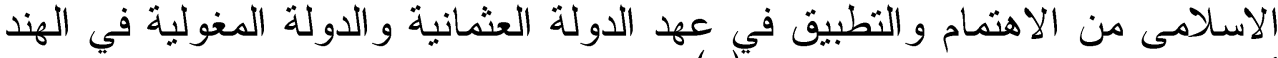

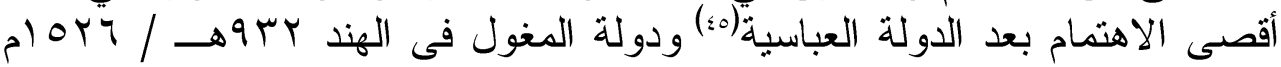

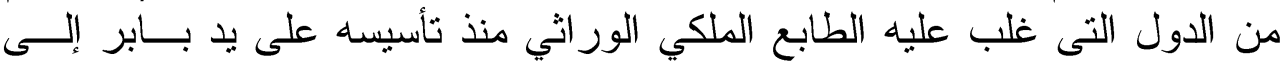

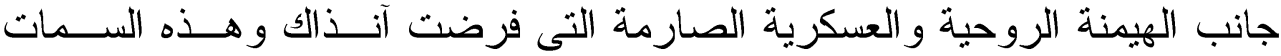

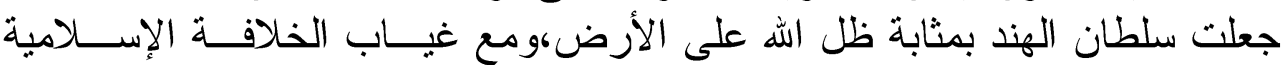

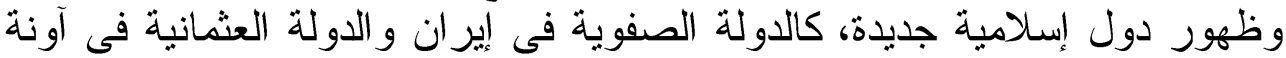

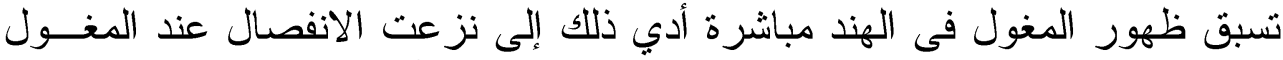

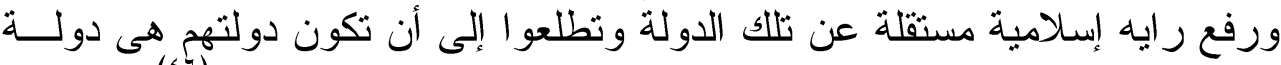

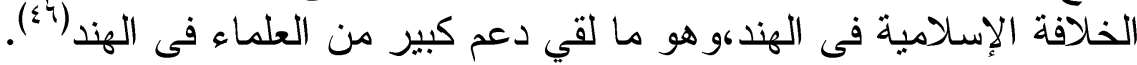

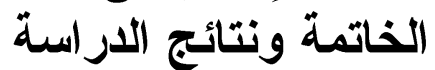

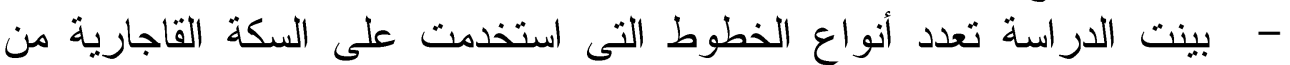

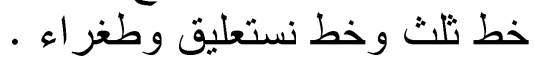

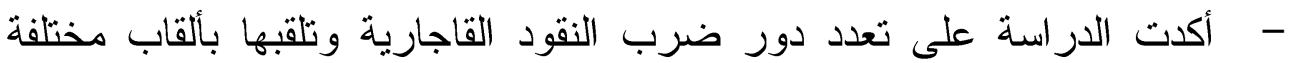
منها دار الخلافة ودار العلم ومشهد مقدس ورغير ها من ألقاب دور الضرب.

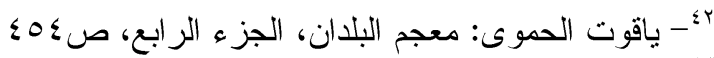

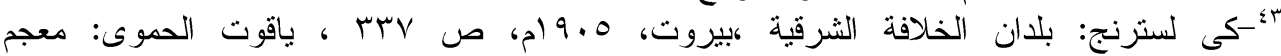

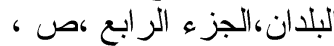

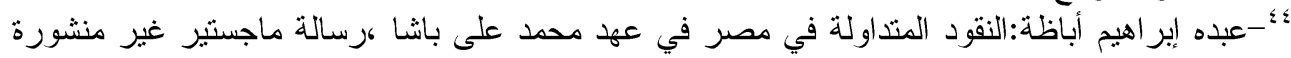

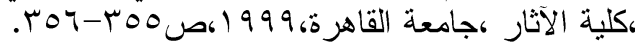

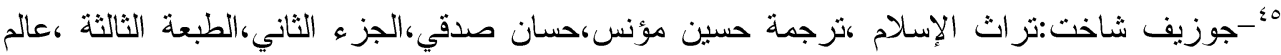

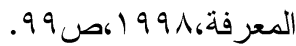

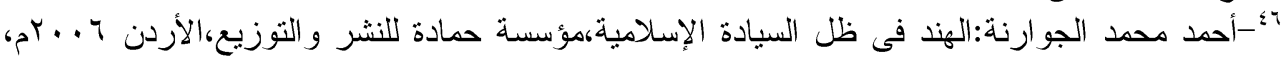




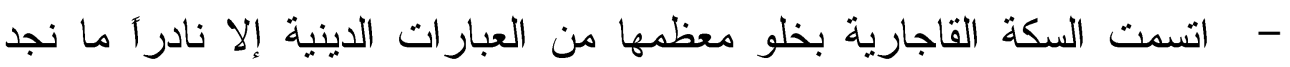

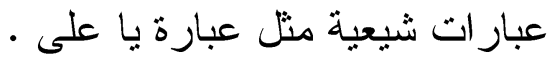

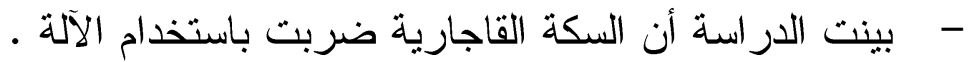

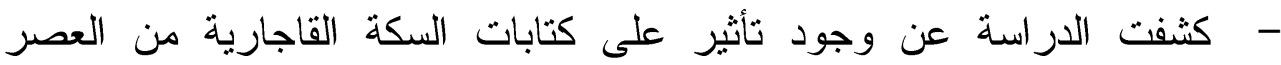
العثمانى فى استخدام الطغر اءع على العملة.

\section{المراجن}

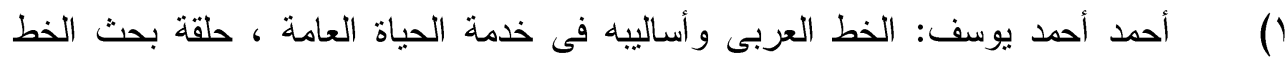

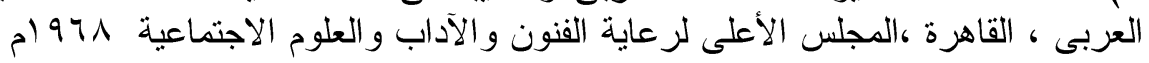

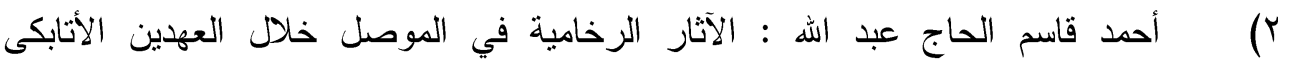

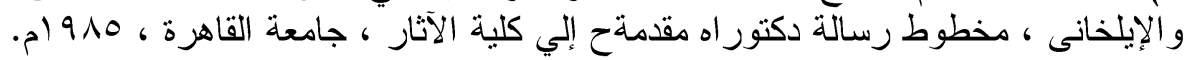

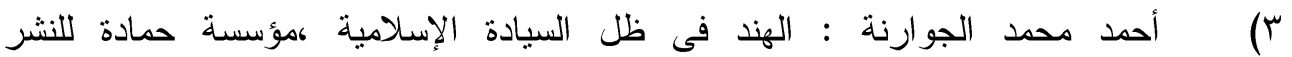

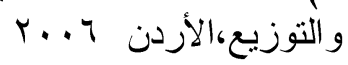

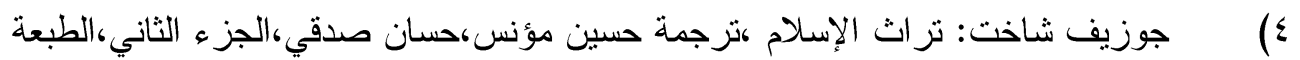

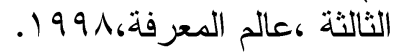

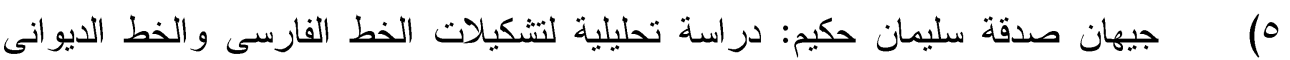

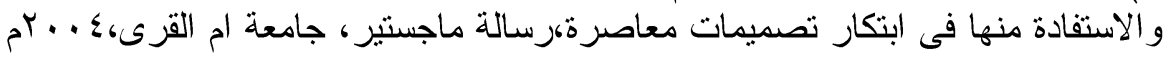

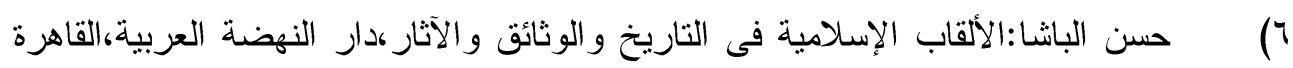
5) $9 \vee \lambda_{6}$

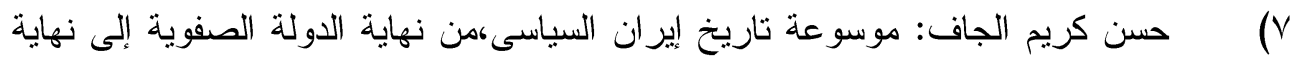

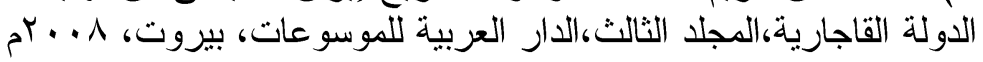

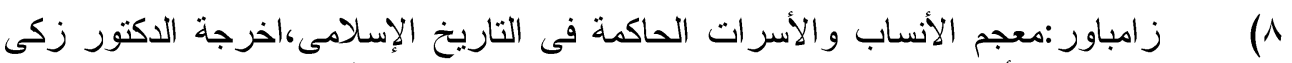

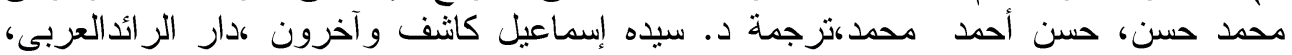

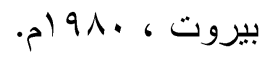

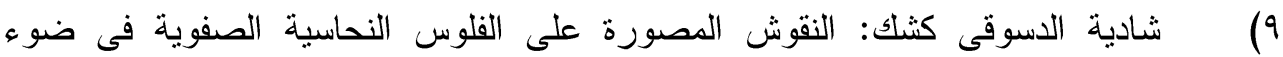

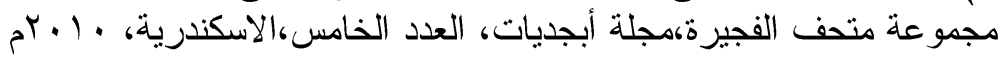

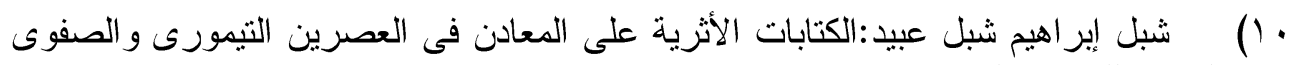

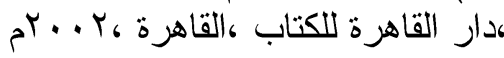

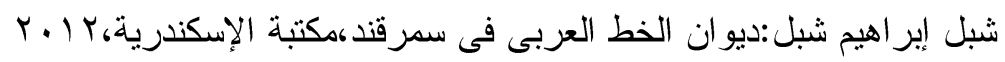

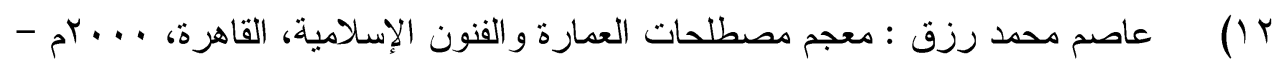

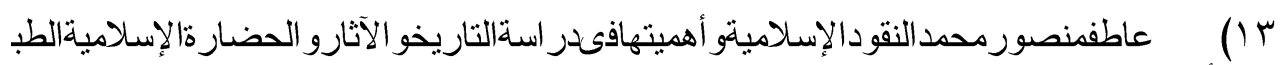

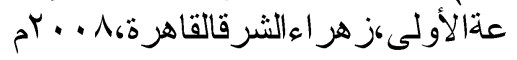

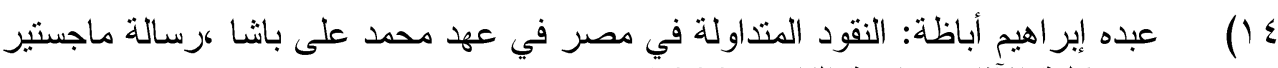

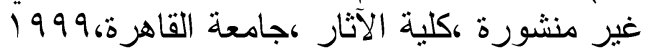

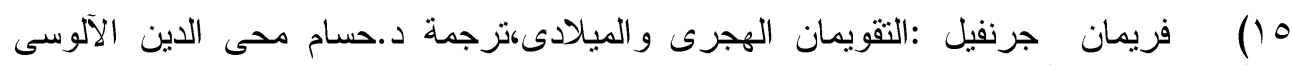

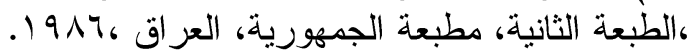

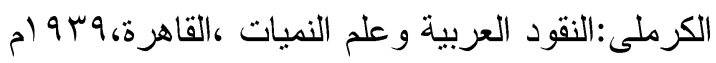




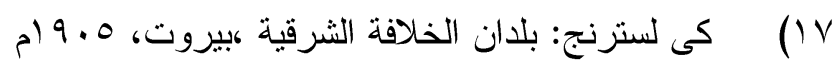

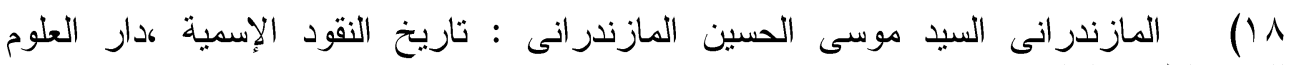

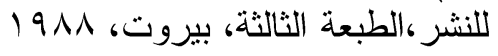
9 (1) ) ماهر سمير عبدالسميع السيد : النقوش الكتابية الثيعية على الفنون الإسلامية الإيرانية في العصر الصفوي " در اسة أثرية فنية " ، رسالة ماجستير ، قسم الآثار الإسلامية ، كلية الآثار

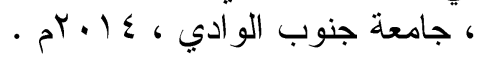

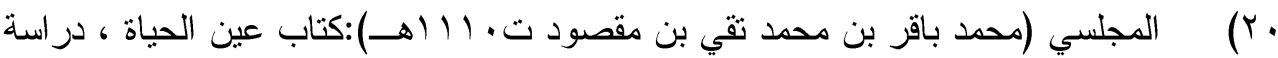

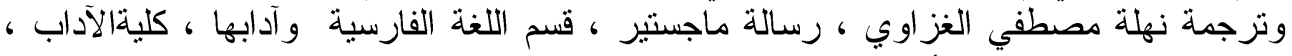

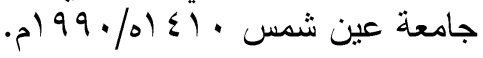

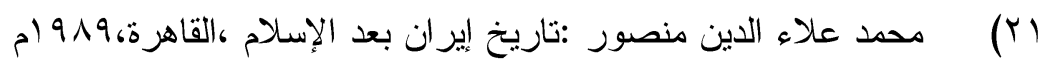

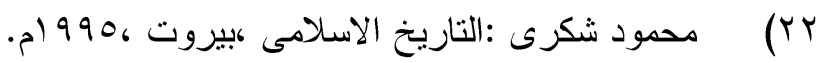

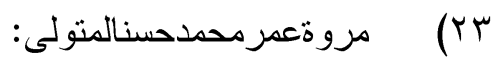
التصاوير الآدميةو الحيو انيةعلىىالخزفو المعادنو النقودالقاجاريتفقىضو عمجمو عةجديدة -در اسة آثرية

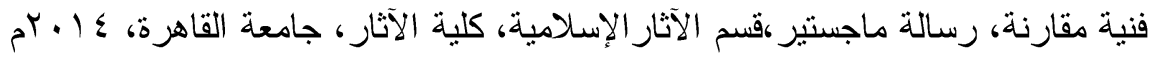

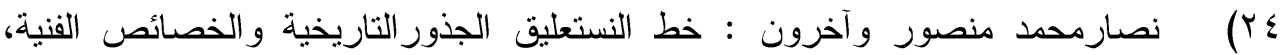

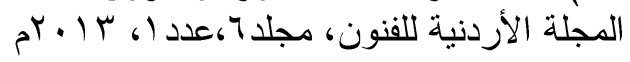

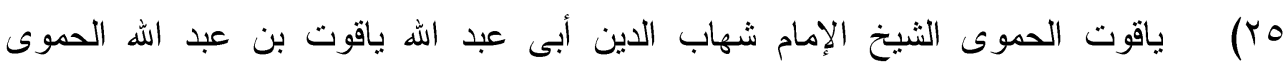

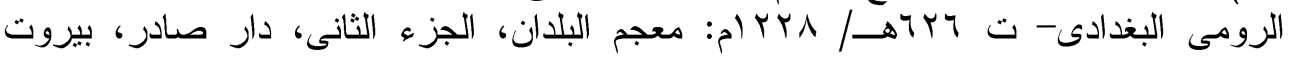
م) $9 \vee V$

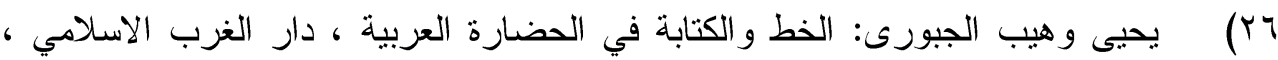

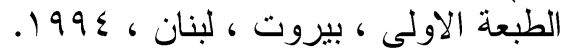
(YV

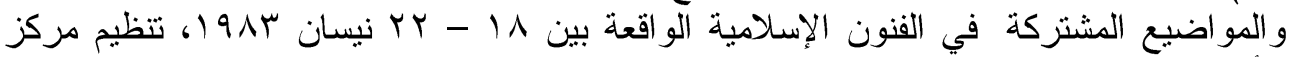

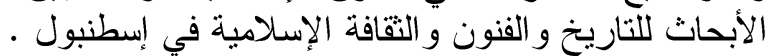

1-Annemarie Schimmel:calligraphy and islamic culture,London,1990

2-H.L.rabino di Borgomale:Coins ,Medals, and Seals of Shahs of Iran‘15001941,Texas, 1973,P64 .

3-Latifeh E.Hagigi :Qajar Royal Succession on the Case of Muzaffer Al din Mirza

'Adiserrtation submitted to the faculty of the university of Uthan'2012.

4-Luschey - Schmeisser : The Pictorial Tile Cycle of Hast Behest in Isfahan and Icono Graphic Tradition ,Vol.XIV,Ismeo - Rome , 1978 ,Pl.LXIX, Fig. 127.

5-Priscilla Soucek : Coinage of the Qajars: A System in Continual Transition ,Iranian Studies, Vol. 34, No. 1/4, Qajar Art and Society 2001, p. 51

6-Regwald Stuart Poole,LL.D: Catalouge of coins of the shahs of persia in the british Museum ,London, 1887.

7-Reginald stuart poole: The coins of the shahs of PersiarZand and Kajars,London, 1887. 

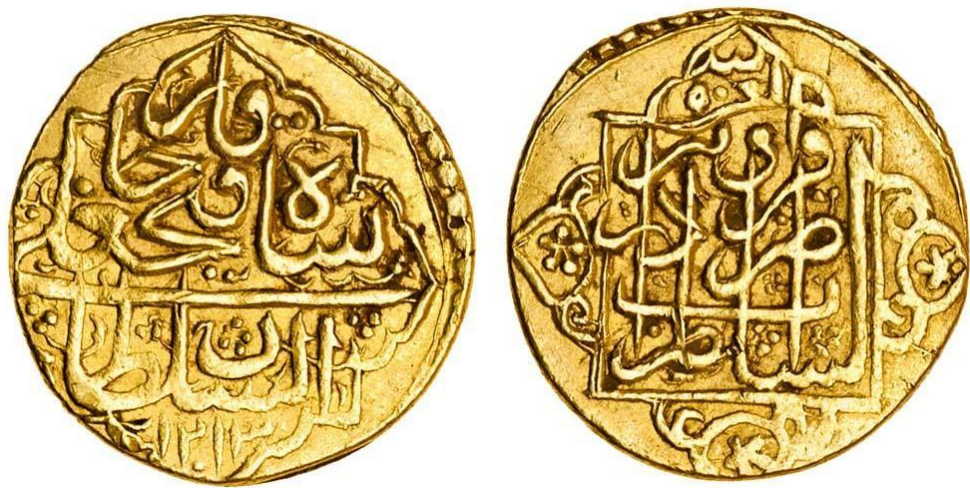

لوحة(1) تومان من عهد فتح على شاه قاجار،وزنه 7 أوجرام، ضرب دار السلطنة قزوين،

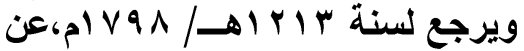

http://www.coinarchives.com/w/results.php?search=qajar
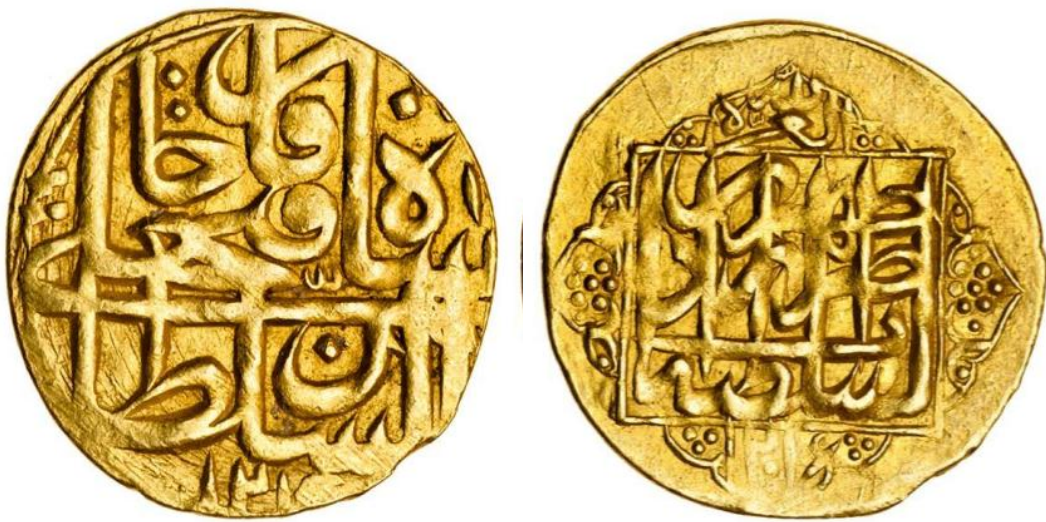

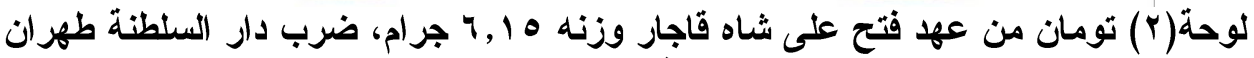

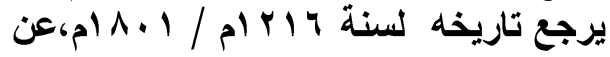

http://www.coinarchives.com/w/results.php?search=qajar
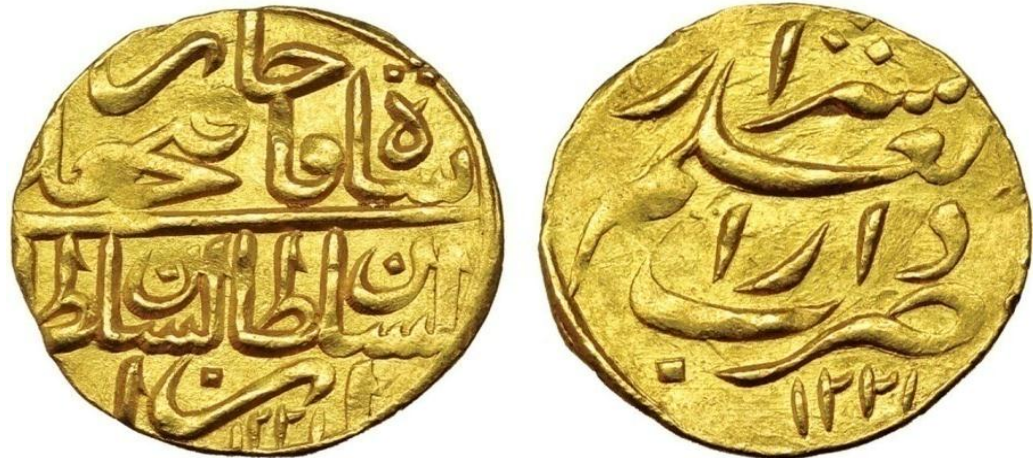

لوحة(r) تومان من عهل فتح على شاه قاجار، ضرب دار العلم شيراز،

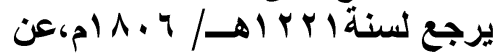

http://www.coinarchives.com/w/results. php?search=qajar 


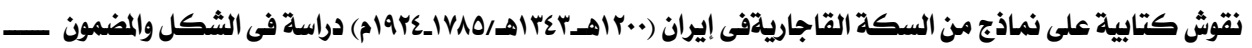
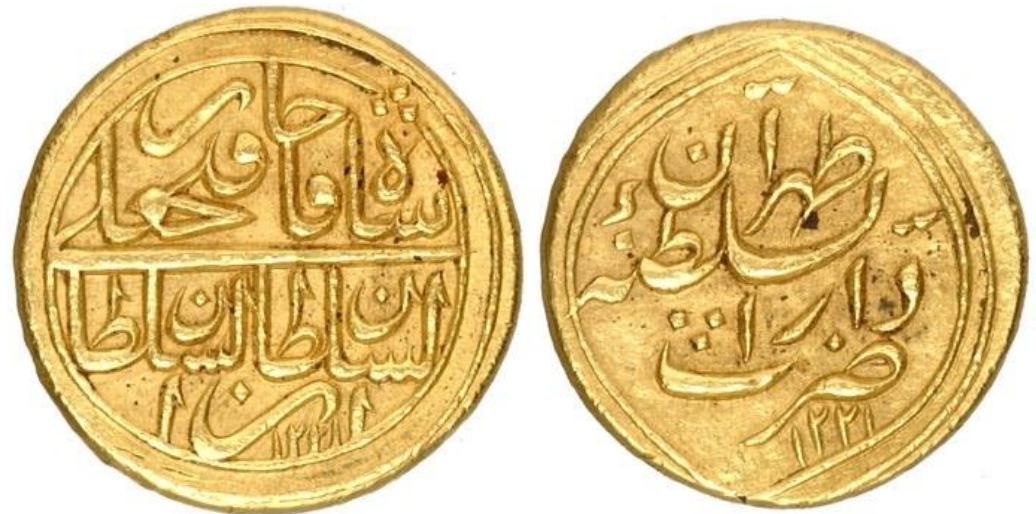

لوحة(ع) تومان من عه فتح على شاه قاجار، ضرب دار السلطنة طهران ،

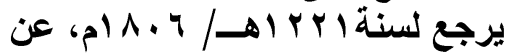

http://numismatics.org/collection/1922.211.883
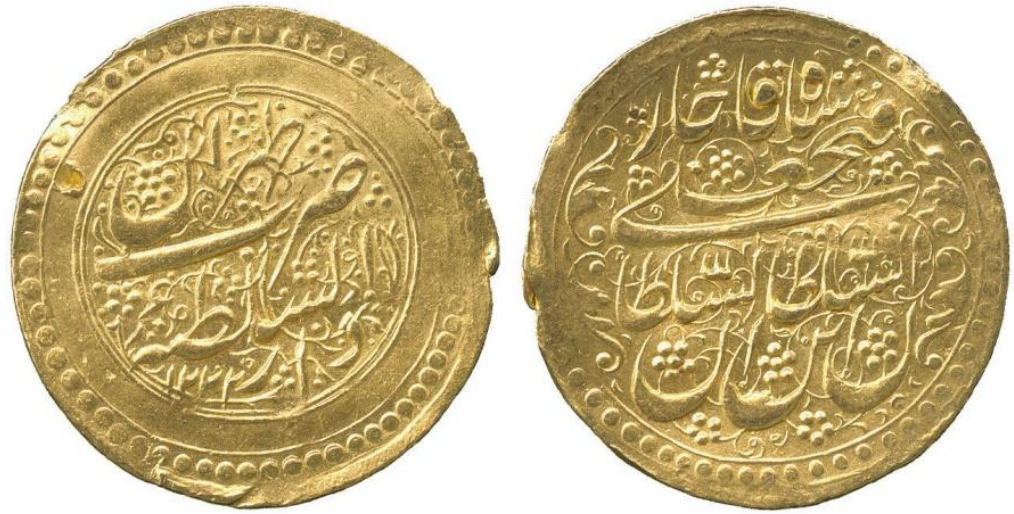

لوحة(0) تومان ذهبى من عهد فتح على شاه قاجار،وزنـه ه,ه جرام، ضرب دار ار السلطنة

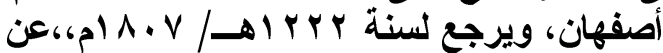

http://www.coinarchives.com/w/results.php?search=qajar
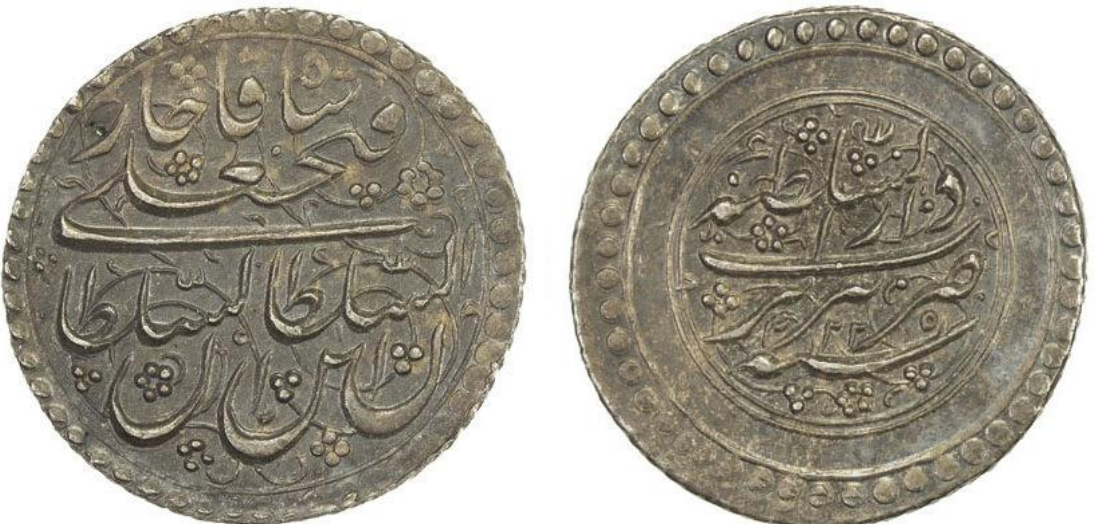

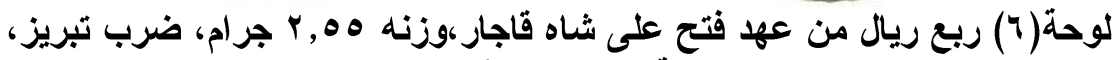

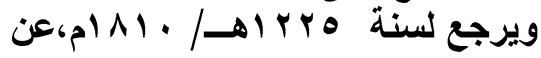

http://www.coinarchives.com/w/results.php?search=qajar 

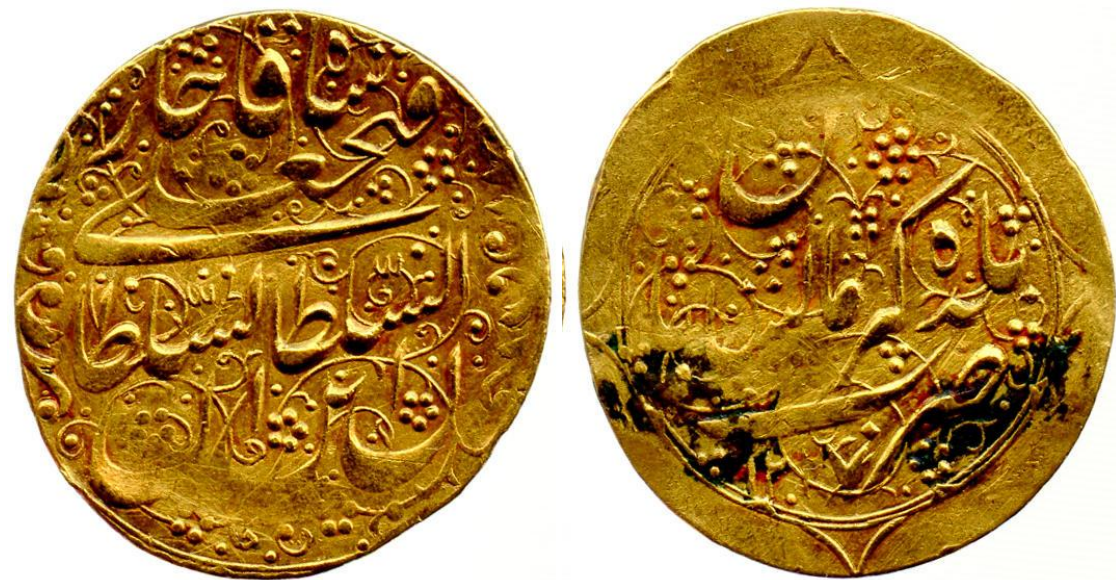

لوحة(V) تومان من عهد فتح على شاه قاجار ضرب بلاة كرمانشاه، وزنه ع هر عجرام

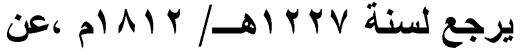

http://www.coinarchives.com/w/results.php?search=qajar
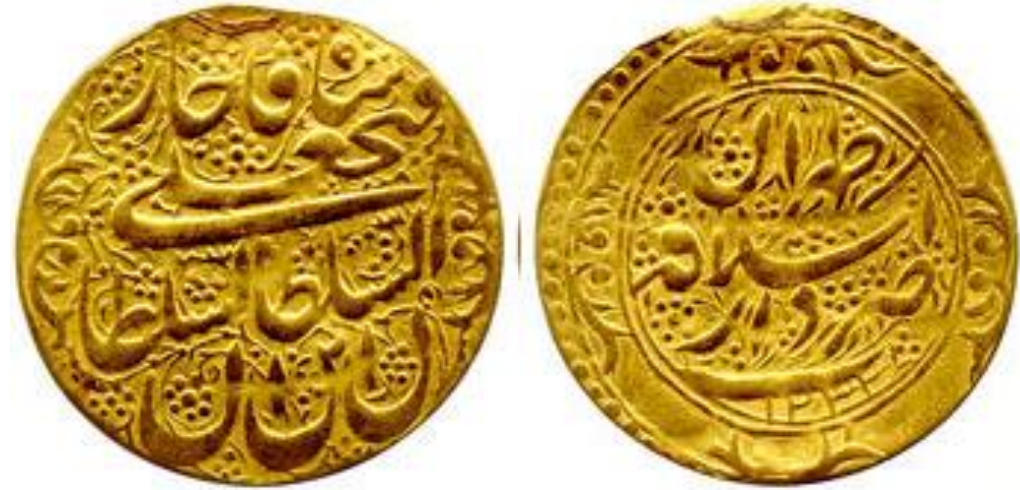

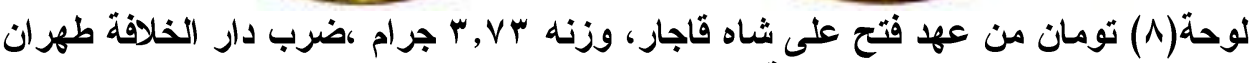

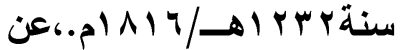

http://www.coinarchives.com/w/results.php?search=qajar
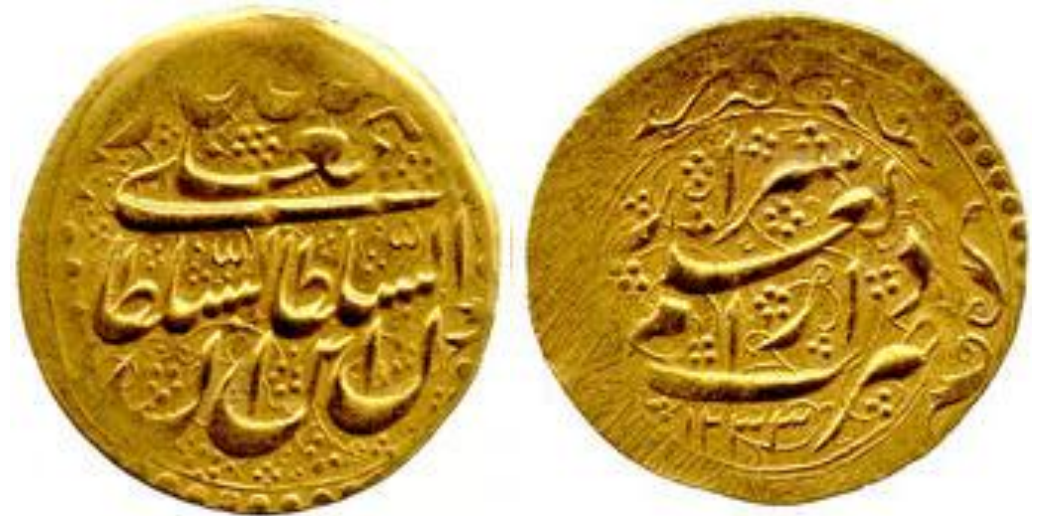

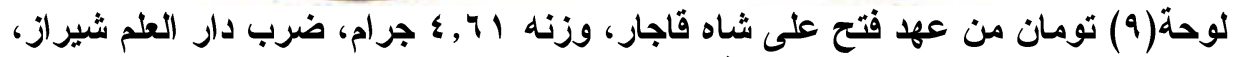

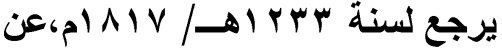

http://www.coinarchives.com/w/results.php?search=qajar 

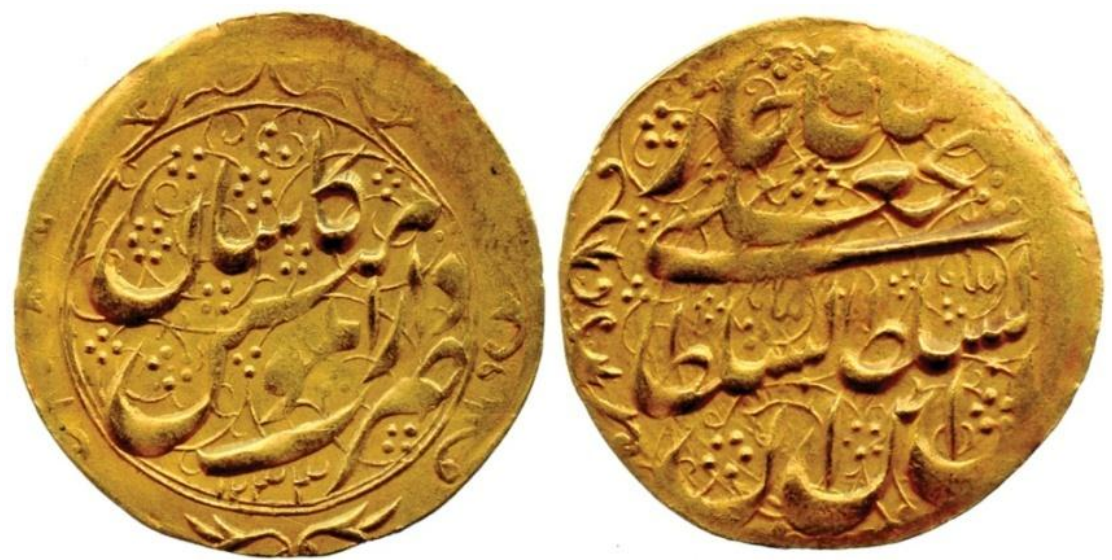

لوحة( · 1) تومان من عهد فتح على شاه قاجار، ضرب دار المؤمنين قاشان،

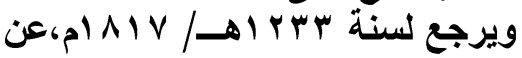

http://www.coinarchives.com/w/results.php?search=qajar
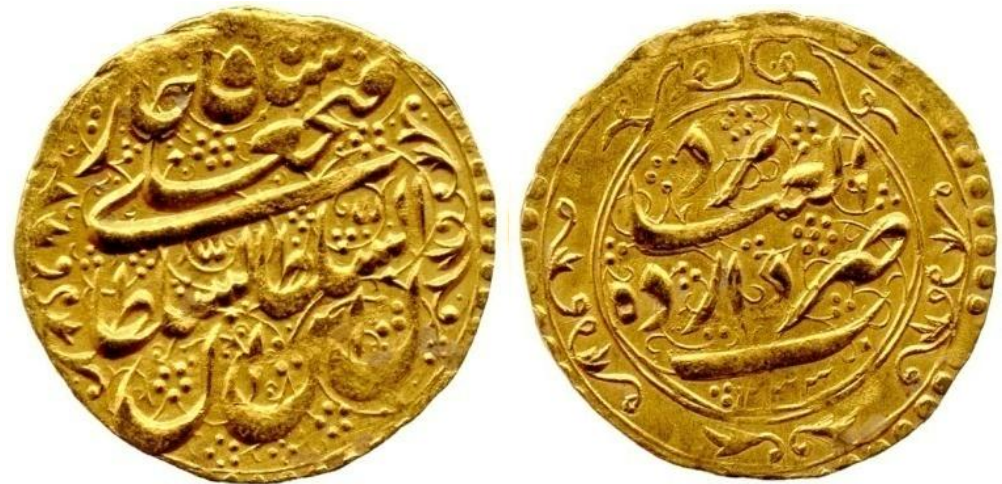

لوحة(1 1 ) تومان من عهد فتح على شاه قاجار، وزنه بآ, عجرام، ضرب دار العبادة يزد

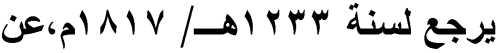
http://www.coinarchives.com/w/results.php?search=qajar
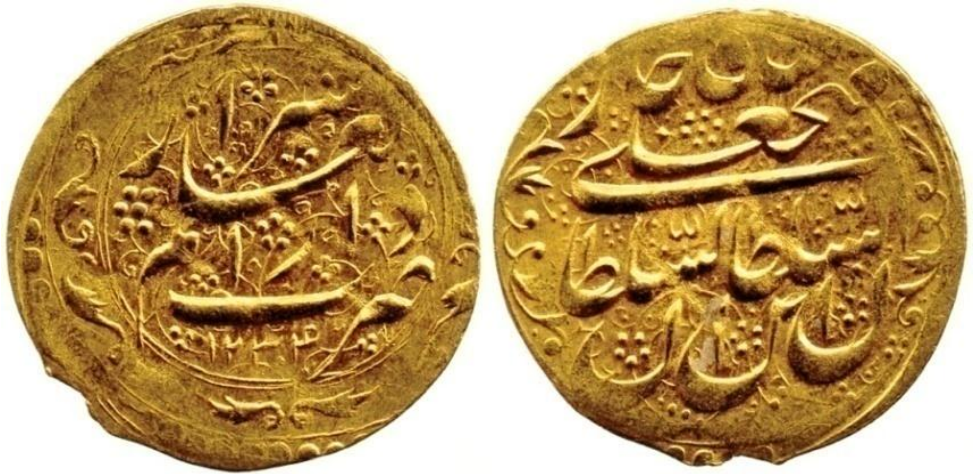

لوحة(r I) تومان من عهد فتح على شاه قاجار،وزنه 17 , عجرام،ضرب دار العلم شيراز،

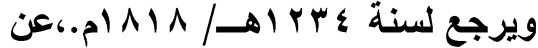

http://www.coinarchives.com/w/results.php?search=qajar 


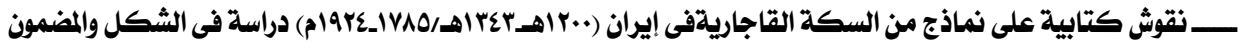
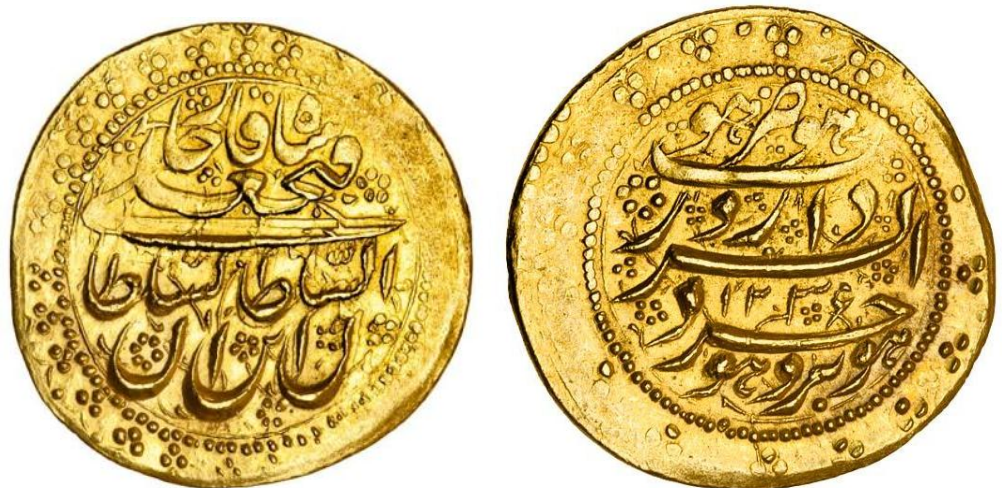

لوحة( ا I) تومان من عهد فتح على شاه قاجار ،وزنه ه †, ؛ جر ام ضرب دار السرور بورجرد

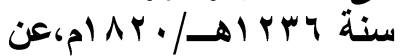

http://www.coinarchives.com/w/results.php?search=qajar
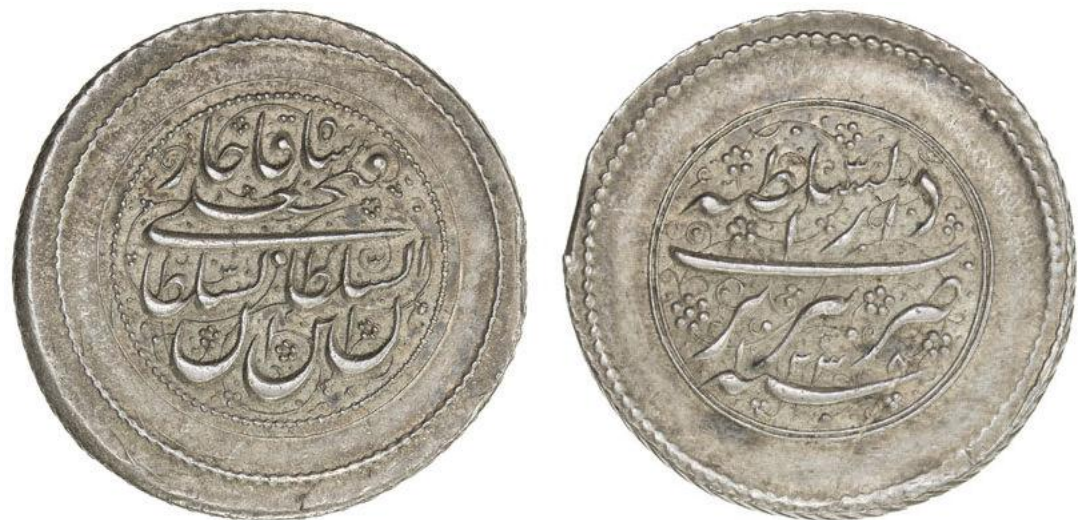

لوحة(ع 1) ريال من عهد فتح على شاه قاجار،وزنه 9 (9 19 جرام، ضرب تبريز،

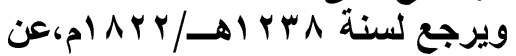

http://www.coinarchives.com/w/results.php?search=qajar
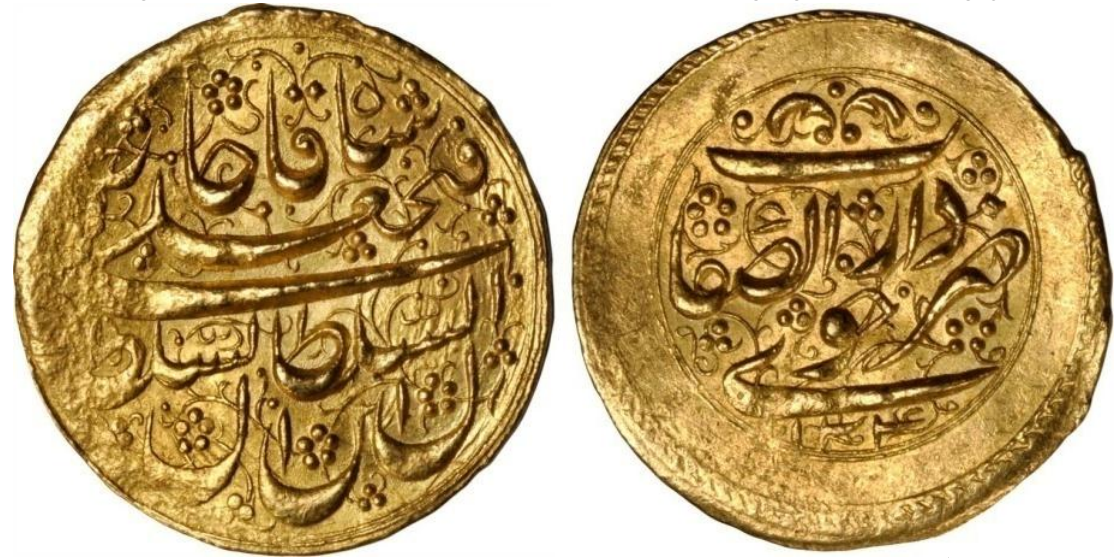

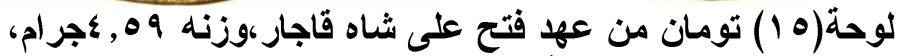

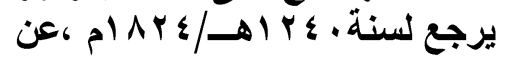

http://www.coinarchives.com/w/results.php?search=qajar 


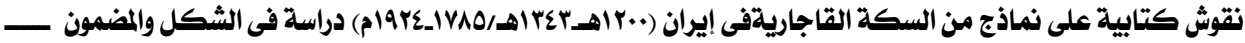
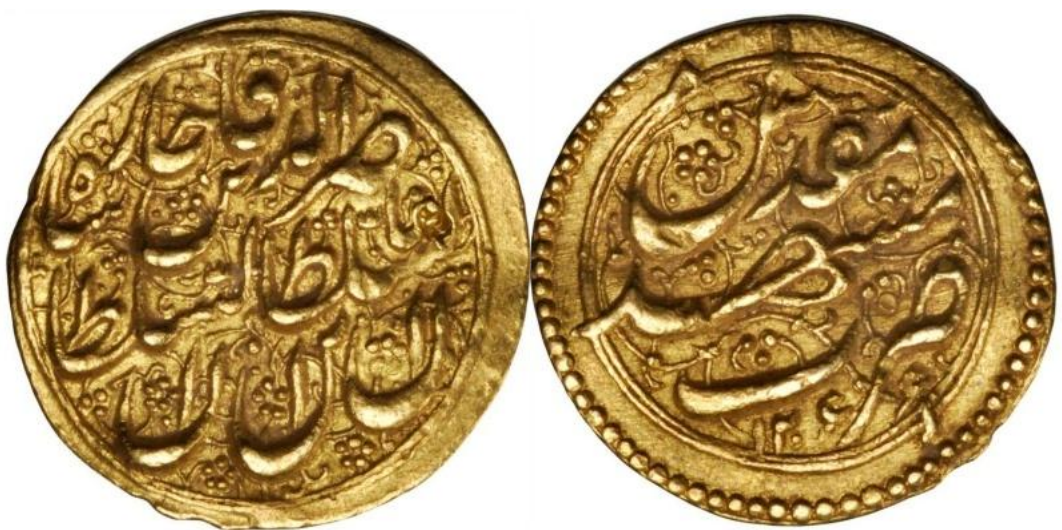

لوحة( آ 1) تومان من عهد ناصر الاين شاه قاجار، ضرب مدينة مشهر،

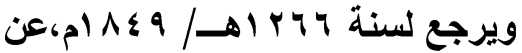

http://www.coinarchives.com/w/results.php?search=qajar
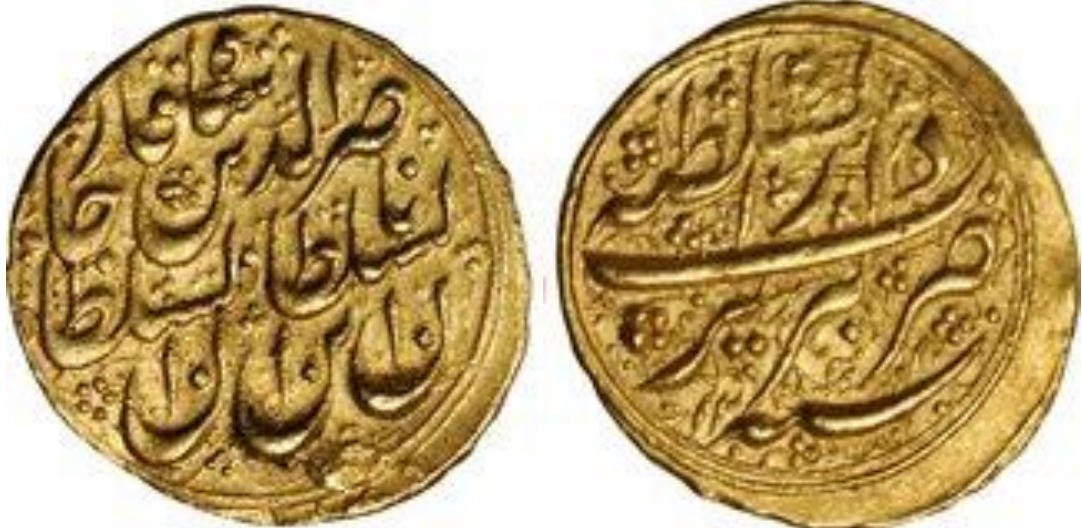

لوحة) ( V تومان من عهل ناصر الاين شاه قاجار محفوظ بمجموعة الامم المتحدة للتقود

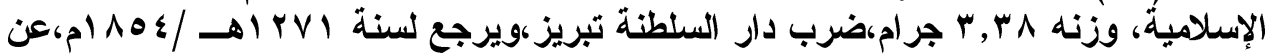
http://www.coinarchives.com/w/results.php?search=qajar
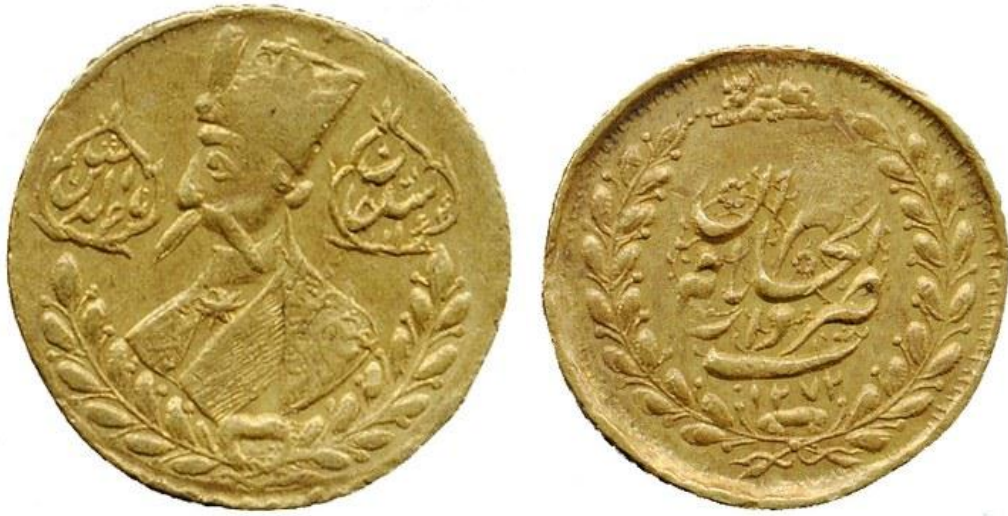

لوحة(1 أ) تومان من عهد ناصر الاين شاه قاجار محفوظ بمجموعة الامم المتحدة للنقود

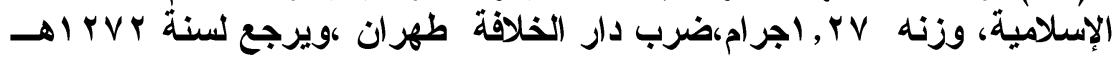

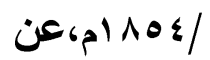

http://numismatics.org/collection/1974.26.845 


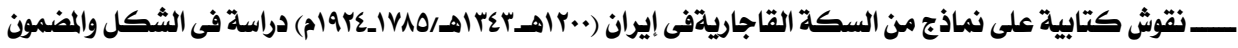
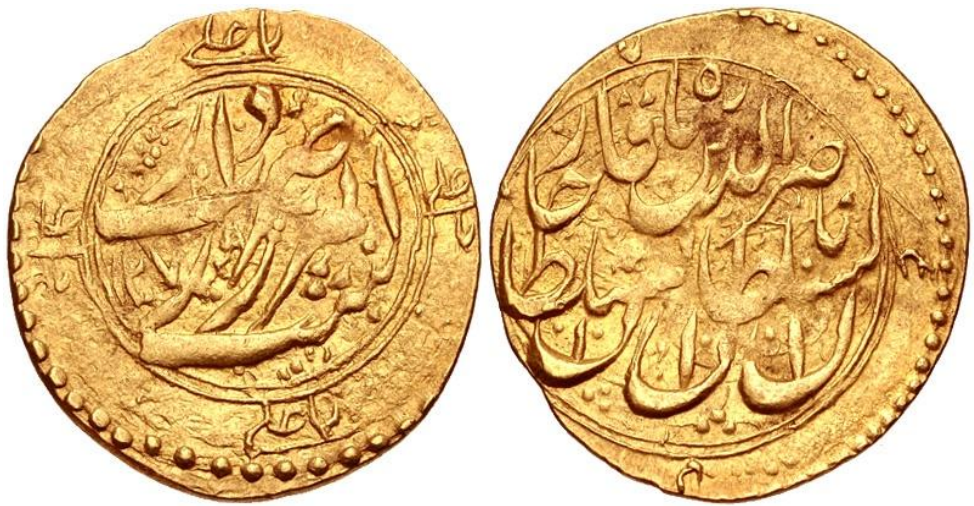

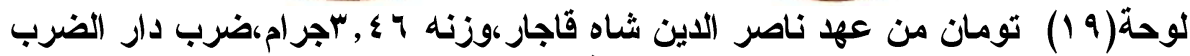

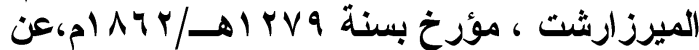

http://www.coinarchives.com/w/results.php?search=qajar
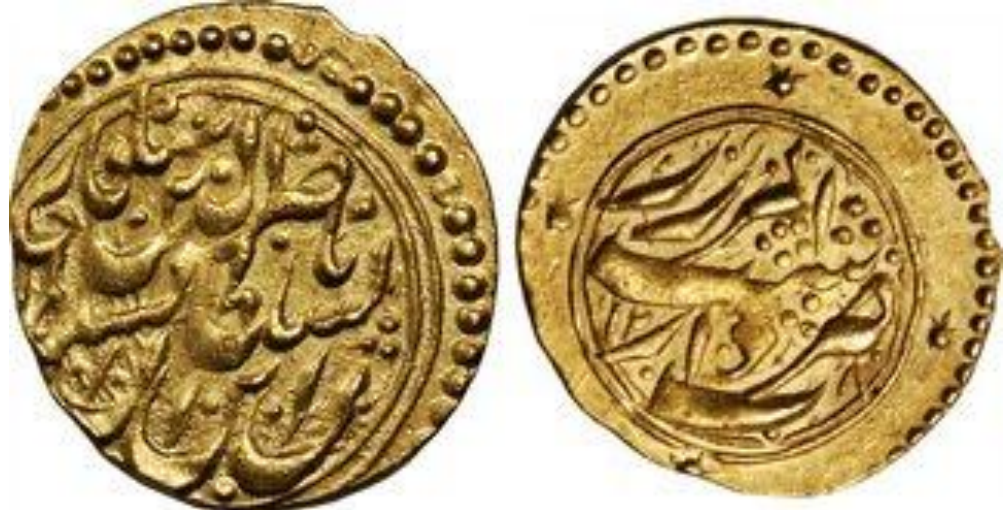

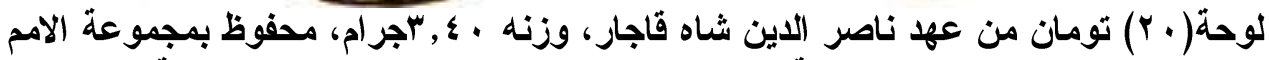

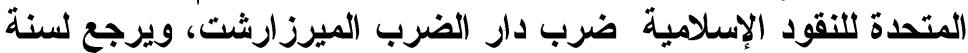

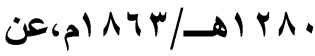

http://www.coinarchives.com/w/results.php?search=qajar
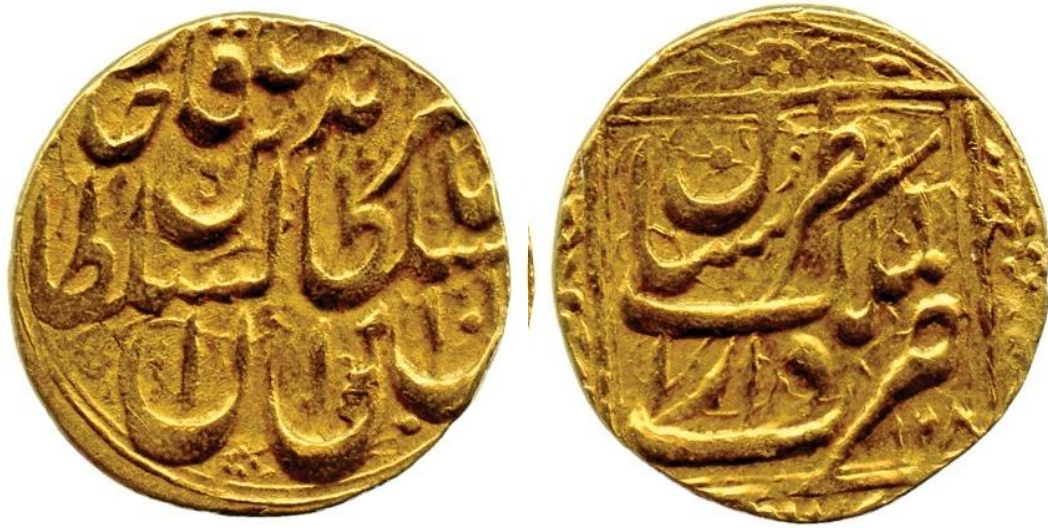

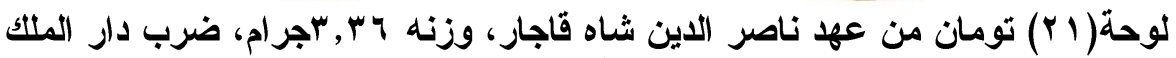

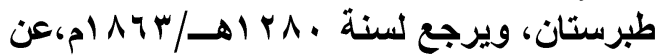

http://www.coinarchives.com/w/results.php?search=qajar 


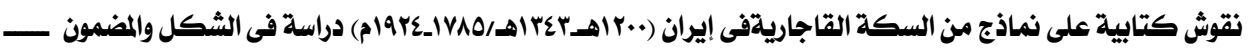

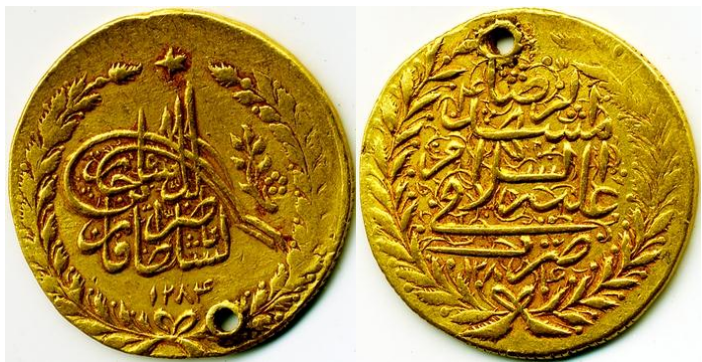

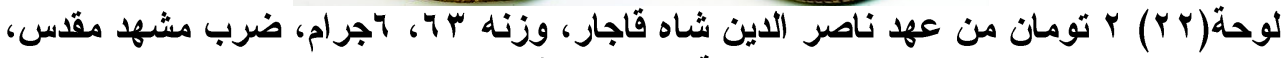

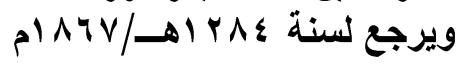

http://numismatics.org/collection/1922.211.1010
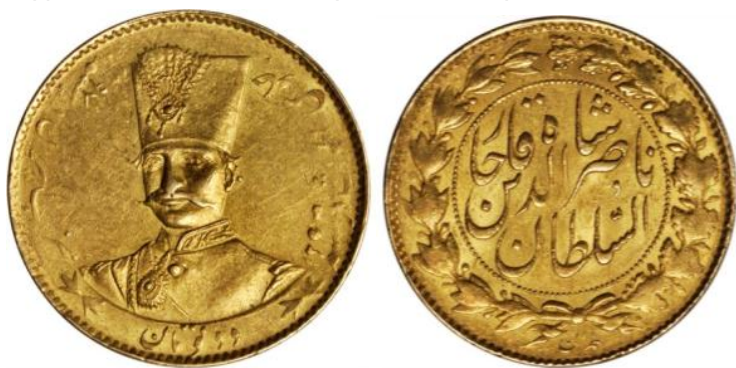

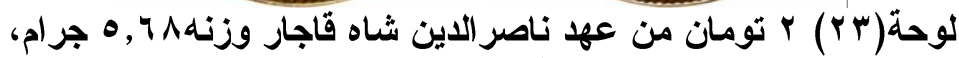

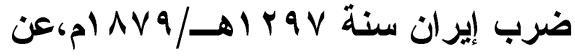

http://www.coinarchives.com/w/results.php?search=qajar
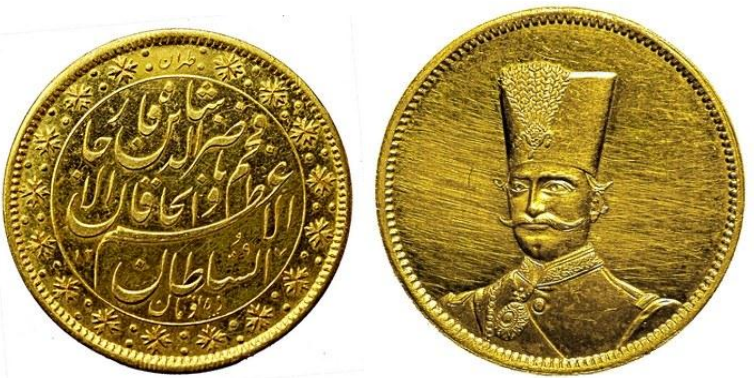

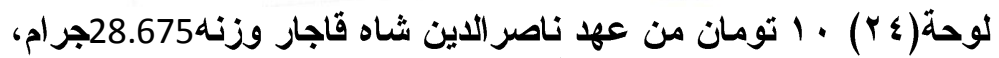

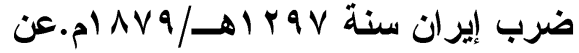

http://numismatics.org/collection/1002.1.2219
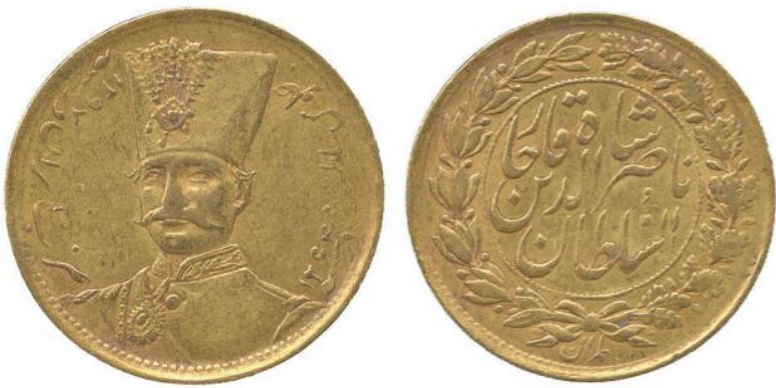

لوحة(ه) تومان ذهبى من عهد ناصر الاين شاه قاجار،ضرب طهران، ويرجع لسنة

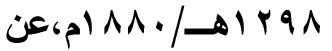

http://www.coinarchives.com/w/results.php?search=qajar 


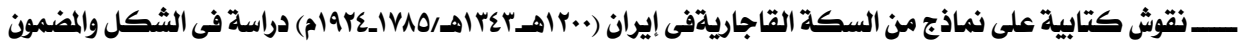
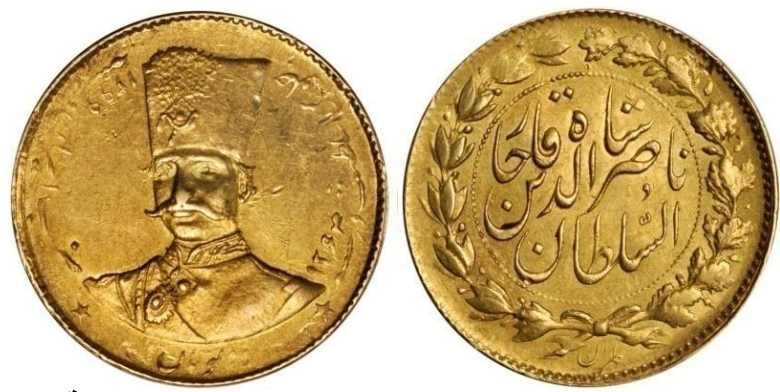

لوحة( ب r r r اتومان من عهد ناصر الاين شاه قاجار محفوظ بمجموعة الامم المتحدة للنقود

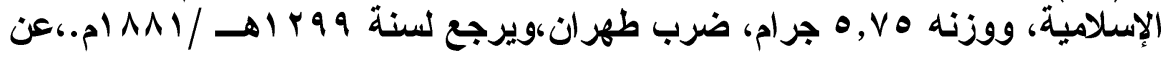
http://www.coinarchives.com/w/results.php?search=qajar
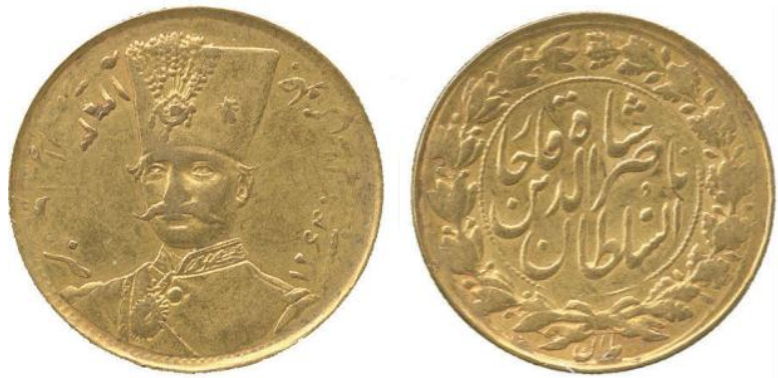

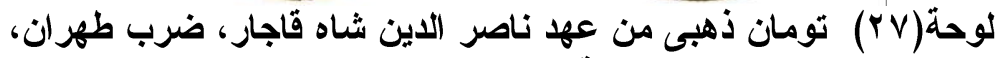

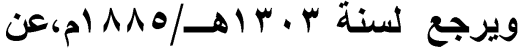

http://www.coinarchives.com/w/results.php?search=qajar
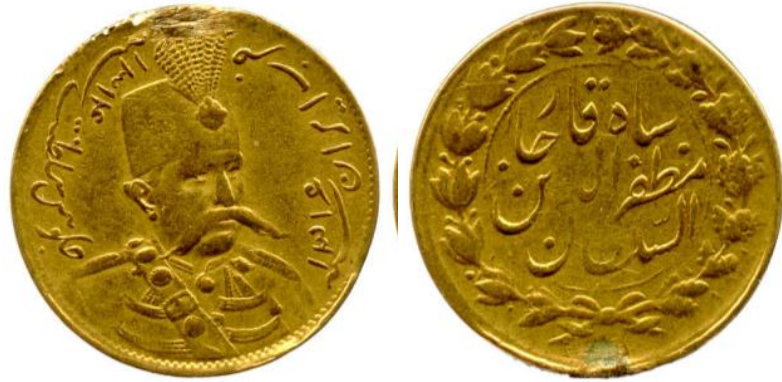

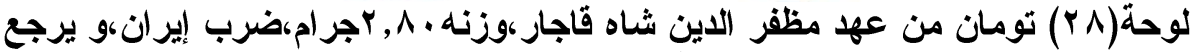

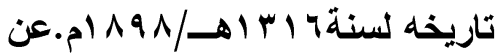

http://www.coinarchives.com/w/results.php?search=qajar
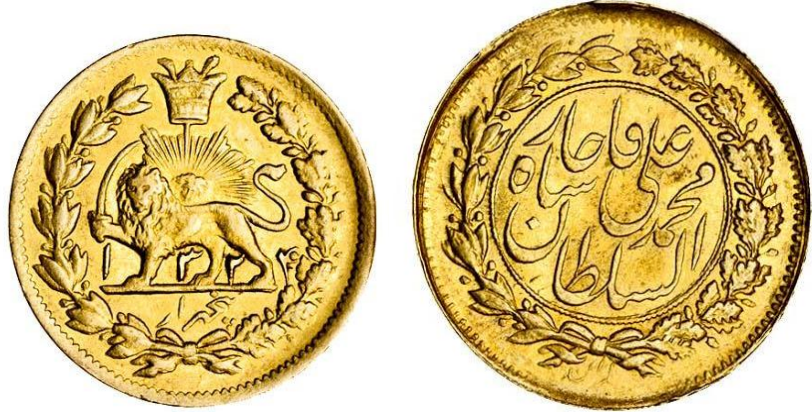

لوحة(q ץ) نصف تومان يساوى ، . . . دينار،وزنه ا ع , اجر ام،ضرب طهران ، 


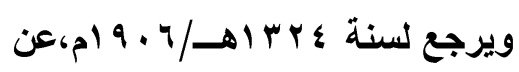

http://www.coinarchives.com/w/results.php?search=qajar
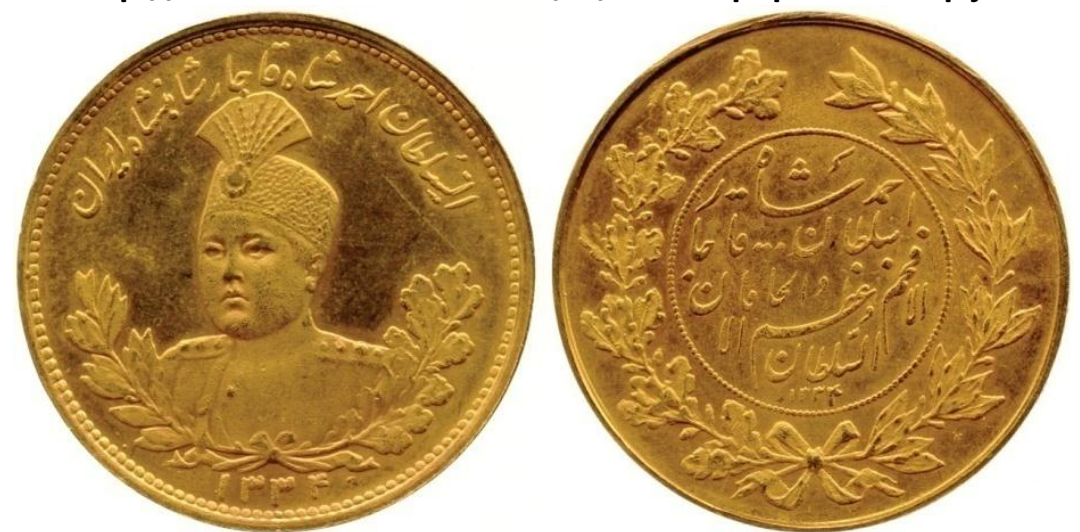

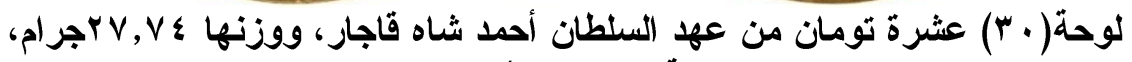

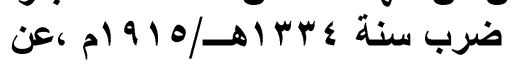

\begin{tabular}{|c|c|c|c|c|c|c|c|c|c|c|}
\hline 9 & 8 & 7 & 6 & 5 & 4 & 3 & 2 & 1 & 0 & الأرقام أعرببة \\
\hline 9 & ᄉ & V & 7 & 0 & $\varepsilon$ & r & $Y$ & 1 & • & الأر قام العرببة النيرقبة \\
\hline 9 & ᄉ & V & 9 & $\Delta$ & $r$ & r & Y & 1 & + & لأر قام العرببة الفارسبة \\
\hline
\end{tabular}

http://www.coinarchives.com/w/results.php?search=qajar

شكل(1) يبين الأرقام العربية،والعربية الثرقية،العربية الفارسية،عن https://ar.wikipedia.org/wiki

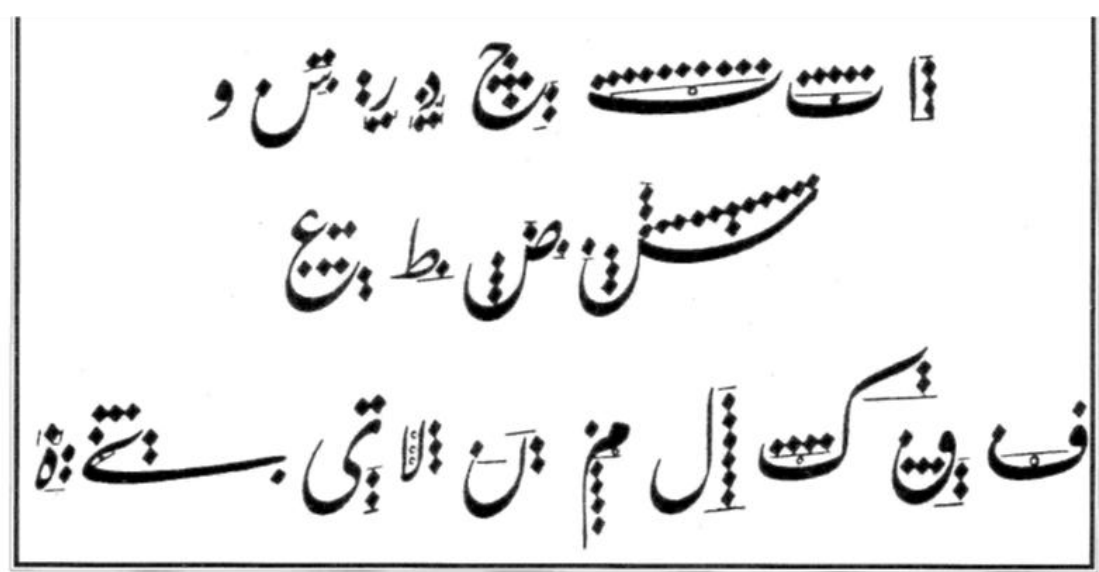

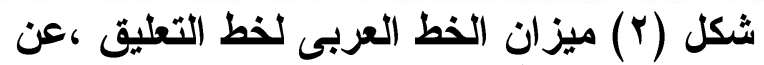

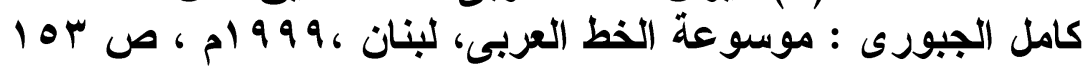

